\title{
Reasoning from the Body: A Historical Perspective on Abortion Regulation and Questions of Equal Protection
}

\author{
Reva Siegel*
}

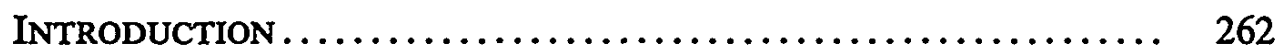

I. Physiological Naturalism in Constitutional

JURISPRUDENCE ............................... 267

A. Physiological Naturalism in Equal Protection Doctrine .... 272

B. Physiological Naturalism and Due Process: Roe v. Wade.. 273

1. Roe's account of women's interests in abortion ....... 273

2. Roe's account of state regulatory interests in abortion . 275

3. Roe's account of the history of abortion regulation .... 277

II. The Nineteenth Century Campaign Against

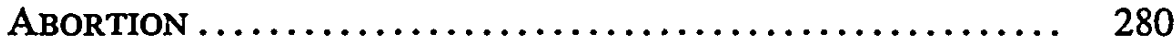

A. Historical Context........................... 281

B. The Doctors' Arguments: The Order of Life ........... 287

1. Maternal/fetal relation....................... 287

2. Marriage................................ 293

3. The state................................ 297

C. The Doctors' Arguments: The Disorder of Life........ 300

1. The aborting wife: antiabortion as antifeminism...... 302

2. Feminism and the concept of voluntary motherhood ... 304

3. Voluntary motherhood: the debate .............. 308

D. The AMA's Accomplishments: The Example of Ohio..... 314

E. A Transformation in the Law of Gender Status .......... 319

III. Fetal-Protective Regulation in Historical

Perspective ................................ 323

A. Physiological Reasoning in Popular Antiabortion

Arguments................................ 324

* Acting Professor of Law, University of California at Berkeley. B.A., 1978, M. Phil., 1982, J.D., 1986, Yale University. I am indebted to the many friends and colleagues who commented on drafts of this article in the various stages of its development: Akhil Amar, Hugh Baxter, Mary Becker, William Fletcher, Paul Gewirtz, Angela Harris, Raoul Ibarguen, Phillip Johnson, Herma Hill Kay, Thomas Laqueur, Christine Littleton, Kristin Luker, Catharine MacKinnon, Robert Post, Deborah Rhode, Harry Scheiber, Frederick Schilling, Martin Shapiro, Marjorie Shultz, Jan Vetter, and Patricia Williams, as well as participants in the Legal History Workshop at Stanford Law School and the Feminist Legal Theory Conference at the University of Wisconsin-Madison. In addition, I owe thanks to Rebecca Schleifer and Laura Schlichtmann for their research assistance, and to Berkeley's Jurisprudence and Social Policy Program for the financial support it provided. 
B. Physiological Reasoning in the Jurisprudence of

Reproductive Regulation ....................... 331

C. Gender Bias in Fetal-Protective Regulation ........... 335

1. Fetal-hazards regulation in employment ........... 336

2. Other forms of fetal-protective regulation ........... 341

IV. REVisiting the Constitutional Question of Abortion . 347

A. Equal Protection Analysis: Some Preliminaries ......... 351

B. The Antidiscrimination Inquiry ................ 354

1. Legislative purpose ....................... 357

2. Legislative means ....................... 359

3. Evidence of gender bias in abortion-restrictive. regulation .......................... 363

C. The Antisubordination Inquiry ................ 368

1. Abortion restrictions coerce childbearing and childrearing ............................. 371

2. The work of bearing and rearing children ......... 372

3. Abortion restrictions as status-enforcing state action ... 377

V. Conclusion ............................ 380

\section{INTRODUCTION}

Controversy surrounding Roe $v$. Wade ${ }^{1}$ has grown steadily in the nearly two decades since the case was decided. Supreme Court appointments by two administrations openly hostile to Roe may finally have presented Roe's original dissenting Justices with the votes needed to overrule or substantially revise the decision. With the prospect of Roe's demise at hand, it is no longer clear what protections, if any, will be afforded the right to abortion, as a matter of federal constitutional law.

The abortion right has been so closely identified with the opinion which first recognized it that their fates now seem inseparable. The most vigorous constitutional objections to protecting the abortion right have been articulated as criticisms of Roe. Constitutional critics of the abortion right have argued that the privacy analysis Roe employed to protect the abortion decision lacks textual support in the Constitution, have questioned whether the abortion decision deserves the same protection as other rights of privacy, and have attacked Roe's trimester framework as imposing unreasonable restraints on the state's interest in protecting potential life. ${ }^{2}$ The apparent premise of such criticism is that if Roe's reasoning is infirm, then so too are the constitutional underpinnings of the abortion right itself. ${ }^{3}$

1. 410 U.S. 113 (1973).

2. See, e.g., Webster v. Reproductive Health Servs., 492 U.S. 490, 518-20 (1989) (plurality opinion); Doe v. Bolton, 410 U.S. 179, 221 -23 (1973) (White, J., dissenting); Roe, 410 U.S. at 171-78 (Rehnquist, J., dissenting); RoBert H. Bork, The Tempting of AMERICA: The Polmical SEDUCTION OF THE LAW 111-16 (1990); John Hart Ely, The Wages of Crying Wolf: A Comment on Roe v. Wade, 82 Yale L.J. 920 (1973); Richard A. Epstein, Substantive Due Process By Any Other Name: The Abortion Cases, 1973 SuP. CT. REV. 159.

3. Justice O'Connor stands alone among prominent critics of Roe in suggesting an alternate, 
Yet, there are serious constitutional concerns presented by abortionrestrictive regulation that Roe does not address. Restricting women's access to abortion implicates constitutional values of equality as well as privacy, as the Court itself suggested in Thornburgh v. American College of Obstetricians and Gynecologists. ${ }^{4} \mathrm{~A}$ growing number of commentators have begun to address abortion regulation as an issue of sexual equality, ${ }^{5}$ articulating concerns scarcely recognized in prevailing accounts of abortion as a right of privacy. Properly understood, constitutional limitations on antiabortion laws, like constitutional limitations on antimiscegenation laws, have moorings in both privacy and equal protection. ${ }^{6}$

although narrower, constitutional framework for the decision. See Thornburgh v. American College of Obstetricians \& Gynecologists, 476 U.S. 747, 828-33 (1986) (O'Connor, J., dissenting); City of Akron v. Akron Ctr. for Reprod. Health, Inc., 462 U.S. 416, $452-75$ (1983) (O'Connor, J., dissenting). But cf. Webster, 492 U.S. at 527-32 (O'Connor, J., concurring in part and concurring in the judgment) (declining to join a plurality opinion that adopts some of her criticisms of the trimester framework).

4. 476 U.S. 747 (1986). Concluding its opinion in Thornburgh, the Court observed:

The Constitution embodies a promise that a certain private sphere of individual liberty will

be kept largely beyond the reach of government. ... That promise extends to women as well as men. . . . A woman's right to make [the abortion] choice freely is fundamental.

Any other result ... would protect inadequately a central part of the sphere of liberty that our law guarantees equally to all.

Id. at 772 (citations omitted). Justice Blackmun discusses both liberty and equality concerns presented by abortion-restrictive regulation in Webster, 492 U.S. at 538 (Blackmun, J., concurring in part and dissenting in part); see text accompanying notes 359-360 infra.

5. See Guido Calabresi, Ideals, Beliefs, Attitudes, and the Law: Private Law Perspectives on a Public law Problem 101-06 (1985); Catharine A. MacKinnon, FemiNISM UNMODIFIED: DISCOURSES ON LIFE AND LAW 93-102 (1987); LAURENCE H. TRIBE, AMERICAN Constitutional LAW § 15-10, at $1353-59$ (2d ed. 1988); Ruth Bader Ginsburg, Some Thoughts on Autonomy and Equality in Relation to Roe v. Wade, 63 N.C. L. REV. 375 (1985); Kenneth L. Karst, Foreword: Equal Citizenship Under the Fourteenth Amendment, 91 HARV. L. REv. 1, 53-59 (1977) [hereinafter Karst, Foreword]; Kenneth L. Karst, Woman's Constitution, 1984 Duke L.J. 447, $472-75$ [hereinafter Karst, Woman's Constitution]; Sylvia A. Law, Rethinking Sex and the Constitution, 132 U. PA. L. REv. 955 (1984); Catharine A. MacKinnon, Reflections on Sex Equality Under Law, 100 YALE L.J. 1281, 1308-24 (1991); Frances Olsen, Unraveling Compromise, 103 HaRv. L. Rev. 105, 117-35 (1989); Donald H. Regan, Rewriting Roe v. Wade, 77 Mich. L. REv. 1569, 1621-45 (1979); Ellen Relkin \& Sudi Solomon, Using State Constitutions to Expand Public Funding for Abortions: Throwing away the Carrot with the Stick, 9 WOMEN's RTS. L. REP. 27 (1986) (privacy and equal protection); Cass Sunstein, Neutrality in Constitutional Law (With Special Reference to Pornography, Abortion, and Surrogacy), 92 CoLUM. L. REV. (forthcoming 1992). For other arguments with deep affinities to the equal protection approach, see Andrew Koppelman, Forced Labor: A Thirteenth Amendment Defense of Abortion, 84 Nw. U. L. REv. 480 (1990); Jed Rubenfeld, The Right of Privacy, 102 HaRv. L. Rev. 737, 788-91 (1989).

For briefs employing an equal protection framework to analyze abortion-restrictive regulation, see, e.g., Brief for the National Coalition Against Domestic Violence as Amicus Curiae Supporting Appellees, Webster v. Reproductive Health Servs., 492 U.S. 490 (1989) (No. 88-605), reprinted in 11 WOMEN'S RTS. L. REP. 281 (1989); Brief of Seventy-Seven Organizations Committed to Women's Equality as Amici Curiae in Support of Appellees, Webster v. Reproductive Health Servs., 492 U.S. 490 (1989) (No. 88-605) (privacy and equal protection), reprinted in 11 WOMEN's RTS. L. REP. 249, 265-67; Brief Amici Curiae on Behalf of the New Jersey Coalition for Battered Women, et al., Right to Choose v. Byrne, 91 N.J. 287, 450 A.2d 925 (1982) (challenging abortion funding restrictions on state constitutional grounds of privacy and equality), reprinted in 7 WOMEN'S RTS. L. REP. 285 (1982).

6. See Loving v. Virginia, 388 U.S. 1, 12 (1967) (striking down antimiscegenation statute on equal protection and due process grounds); cf. Karst, Foreword, supra note 5, at 57 (Supreme Court "decisions protecting 'fundamental' interests related to procreation, marriage, and particularly nonmarriage ... . can be seen as 'woman's role' cases. So viewed, they implicate the principle of equal 
There are, however, substantial impediments to analyzing abortionrestrictive regulation in an equal protection framework, which few proponents of the claim have confronted. The Court has yet to characterize laws governing pregnancy as sex-based state action for purposes of equal protection review; ${ }^{7}$ but, even if it did so, a deeper jurisprudential problem remains. The Court typically reasons about reproductive regulation in physiological paradigms, as a form of state action that concerns physical facts of sex rather than social questions of gender. It has often observed that the reality of reproductive differences between the sexes justifies their differential regulatory treatment. ${ }^{8}$ This mode of reasoning about reproductive regulation obscures the possibility that such regulation may be animated by constitutionally illicit judgments about women. Thus, while sex-based state action is generally scrutinized to ensure it is free of "old notions of role typing" or other vestiges of the separate spheres tradition" - such as the assumption that women are "child-rearers"10 or the assumption that "the female [is] destined solely for the home and the rearing of the family"11_ regulation which directly concerns women's role in reproduction has yet to receive similar scrutiny.

Like any other form of sex-based state action, regulation directed at women's role in reproduction demands exacting scrutiny to ensure it does not reflect or enforce traditional gender role assumptions. Equal protection jurisprudence has repeatedly articulated principles that would support such an inquiry. But current doctrine lacks the critical capacity to discern gender bias in reproductive regulation, a grasp of how regulation respecting pregnancy-a "real" physical difference between the sexes-can nevertheless be

citizenship, for they involve some of the most important aspects of a woman's independence, her control over her own destiny.") (footnotes omitted).

Employing an equal protection framework could prove important in understanding the limitations imposed on abortion regulation, not only by the United States Constitution, but by state constitutions as well. See, e.g., Relkin \& Solomon, supra note 5 (challenging abortion funding restrictions on state constitutional grounds of privacy and equality). It would also affect how courts evaluate fetal-protective regulation outside the abortion context. See, e.g., Dawn E. Johnsen, Note, The Creation of Fetal Rights: Conflicts with Women's Constitutional Rights to Liberty, Privacy, and Equal Protection, 95 YALE L.J. 599 (1986); Dawn Johnsen, From Driving to Drugs: Governmental Regulation of Pregnant Women's Lives After Webster, 138 U. PA. L. REv. 179, 197-204 (1989) [hereinafter Johnsen, From Driving to Drugs] (analyzing fetal-protective regulation of women on privacy and sex equality grounds).

7. See Geduldig v. Aiello, 417 U.S. 484 (1974); text accompanying notes 17-28 infra. But cf. 42 U.S.C. $\$ 2000 \mathrm{e}(\mathrm{k})$ (1988) (distinctions on the basis of pregnancy are distinctions on the basis of sex under federal civil rights law governing employment discrimination). See generally Law, supra note 5 (arguing that regulation governing pregnancy should be analyzed as sex-based state action for purposes of equal protection review).

8. See, e.g., text accompanying note 37 infra.

9. See Craig v. Boren, 429 U.S. 190, 198 (1976); id. at 198-99 (rejecting statutory schemes premised on "increasingly outdated misconceptions concerning the role of females in the home rather than in the 'marketplace and world of ideas' ") (quoting Stanton v. Stanton, 421 U.S. 7, 14-15 (1975)); cf. Mississippi Univ. for Women v. Hogan, 458 U.S. 718, 724-25 (1982) ("Although the test for determining the validity of a gender based classification is straightforward, it must be applied free of fixed notions concerning the roles and abilities of males and females.").

10. Califano v. Webster, 430 U.S. 313, 317 (1977).

11. Stanton, 421 U.S. at 14. 
sexually discriminatory. Without this understanding, analysis of abortionrestrictive regulation cannot be fully assimilated into an equal protection framework.

Abortion-restrictive regulation can be analyzed as an expression of sex discrimination: as legislation that reflects traditional sex-role assumptions about women and presents problems of gender bias discernible in other forms of sex-based state action. But to perform this analysis, it is necessary to break out of the physiological paradigms in which the Court reasons about reproductive regulation in both privacy and equal protection law. More than any doctrinal factor, it is the physiological framework in which the Court reasons about reproductive regulation that obscures the genderbased judgments that may animate such regulations and the gender-based injuries they can inflict on women. When abortion-restrictive regulation is analyzed in physiological paradigms, as past cases have shown, the inquiry focuses on questions concerning gestation. By contrast, if restrictions on abortion are analyzed in a social framework, they present questions concerning the regulation of motherhood, and, thus, value judgments concerning women's roles.

This article employs historical analysis to situate abortion-restrictive regulation in a social framework, building its argument from an account of the original campaign to criminalize abortion during the nineteenth century. Those who advocated restricting women's access to abortion in the nineteenth century were interested in enforcing women's roles, an objective they justified with arguments concerning women's bodies. ${ }^{12}$ Analyzing the historical record reveals how social discourses concerning women's roles have converged with physiological discourses concerning women's bodies, as two distinct but compatible ways of reasoning about women's obligations as mothers. When issues which we habitually conceptualize in terms of women's bodies are reconsidered in light of this history, it is possible to see that they in fact involve questions concerning women's roles. Considered from this perspective, abortion-restrictive regulation presents many of the concerns that have traditionally triggered heightened equal protection scrutiny.

The article is organized in four parts. Part I identifies a central analytic deficiency in constitutional doctrines governing reproductive regulation: The Court addresses reproduction as if it were primarily a physiological process and evaluates its regulation in terms focused on the female body. This tendency, which I call "physiological naturalism," informs both equal protection law and the analysis of abortion-restrictive regulation offered in Roe. Consequently, abortion-restrictive regulation has been evaluated in ways that obscure the social norms that shape women's interests in abortion, as well as public interest in its regulation.

To illustrate the critical limitations and historical lineage of this naturalistic framework, Part II offers a detailed account of the nineteenth century

12. See, e.g., text accompanying notes 121-133 infra. 
campaign to criminalize abortion. The doctors who led the nineteenth century campaign attacked abortion in the physiological disccurse of their profession, depicting the practice as inimical to diverse aspects of social life. They emphasized that restricting women's access to abortion was necessary, not only to protect the unborn, but also to ensure that women performed their obligations as wives and mothers and to preserve the ethnic character of the nation. Analysis of the criminalization campaign demonstrates that abortion-restrictive regulation may be driven in significant part by constitutionally illicit concerns, reflecting normative judgments about women, not simply concern for the unborn. At the same time, this inquiry reveals that physiological modes of reasoning about women's reproductive role have a social history: From the criminalization of abortion to the protective legislation upheld in Muller v. Oregon, ${ }^{13}$ physiological argument has played an important role in justifying regulation that enforces relations of gender status.

Part III considers contemporary interest in protecting unborn life in light of the nineteenth century campaign. Claims about women's roles openly voiced in the nineteenth century do not appear in arguments for protecting unborn life today. Upon closer examination, however, it can be seen that gender-based judgments do continue to inform arguments for regulation of women's reproductive conduct; today these judgments can be articulated in the physiological modes of argument the campaign inaugurated. If one analyzes the incidence and structure of fetal-protective regulation, it is possible to see that such regulation reflects social judgments about women's roles, and not simply solicitude for the welfare of the unborn. The diverse means a society employs to promote the welfare of unborn generations reflect varying normative judgments about women and have dramatically different effects on women's lives.

Part IV employs the historical and critical perspectives developed throughout the article to analyze abortion-restrictive regulation in an equal protection framework. Legislation restricting women's access to abortion forces women to bear children. Today, as in the past, a legislature's decision to save fetal life by compelling pregnancy is one that both reflects and enforces social judgments concerning women's roles. This can be seen by analyzing the incidence and structure of abortion-restrictive regulation, a process which illuminates the types of gender bias that may animate such regulation and the types of injuries it can inflict on women. So analyzed, it is clear that abortion-restrictive regulation can violate the antidiscrimination and antisubordination principles which give the constitutional guarantee of equal protection its meaning.

13. 208 U.S. 412 (1908). 


\section{Physiological Naturalism In Constitutional JuRisPRUdence}

Clearly, reproduction has been regarded as quite different from other natural functions which, on the surface, seem to be equally imbued with necessity; eating, sexuality and dying, for example, share with birth the status of biological necessities. Yet it has never been suggested that these topics can be understood only in terms of natural science. ${ }^{14}$

Mary O'Brien (1981)

Social forces play a powerful part in shaping the process of reproduction. Social forces define the circumstances under which a woman conceives a child, including how voluntary her participation in intercourse may be. Social forces determine whether a woman has access to methods of preventing and terminating a pregnancy, and whether it is acceptable for her to use them. Social forces determine the quality of health care available to a woman during pregnancy, and they determine whether a pregnant woman will be able to support herself throughout the term of gestation, or instead will be forced to depend on others for support. Social relations determine who cares for a child once it is born, and what resources, rewards, and penalties attend the work of gestating and nurturing human life.

Thus, human reproduction is not simply a physiological process; like eating and dying, it is a social process, occurring in and governed by culture. In each culture, norms and practices of the community, including those of family, market, medicine, church, and state, combine to shape the social relations of reproduction. If physiological forces seem to define the process of reproduction, it is because most cultures reason about the social relations of reproduction as part of the physical relations of reproduction, that is, as unalterable aspects of nature; ideologies of gender sustain these habits of thought. Ideological norms and institutional practices pertaining to reproduction play a central part in defining women's status, the dignity they are accorded, the degradations to which they are subjected, and the degree of autonomy they are allowed or dependency they must suffer. These norms and practices affect women who are mothers most intensely, but in one way or another they affect all women.

These observations, tenets of anthropological and feminist critical thought, ${ }^{15}$ do not inform the reasoning of those charged with interpreting the Constitution. In crafting equal protection and due process doctrine concerning reproductive regulation, the Court has typically reasoned from the premise that women's reproductive role is dictated by nature, and that regulation of women's reproductive conduct can be evaluated by consulting facts of nature. The result is that social relations enforced by the body politic

14. Mary O'Brien, The Politics of Reproduction 20 (1981).

15. See, e.g., Rosalind Pollack Petchesky, Abortion and Woman's Choice: The State, Sexuality ANd Reproductive Freedom (rev. ed. 1990); WoMAN, Culture, AND SociETY (Michelle Zimbalist Rosaldo \& Louise Lamphere eds., 1974); Joan Kelly-Gadol, The Social Relations of the Sexes: Methodological Implications of Women's History, in THE Signs ReADER 11 (Elizabeth Abel \& Emily K. Abel eds., 1983). 
often find constitutional justification in the organization of the female body itself. The interpretive assumptions of physiological naturalism inform both equal protection and due process doctrine, inhibiting judicial scrutiny of the social norms and practices that shape reproduction and its regulation. Consequently, both privacy and equal protection precedents governing regulation of women's reproductive lives are inordinately preoccupied with the physiological character of women's reproductive role and correspondingly inattentive to the social logic of its regulation.

\section{A. Physiological Naturalism in Equal Protection Doctrine}

The Court's equal protection rulings on reproductive regulation have drawn abundant criticism. They were announced early in the development of constitutional sex discrimination doctrine, but, to date, the Court has not seen fit to elaborate upon or to amend them. In Cleveland Board of Education v. LaFleur ${ }^{16}$ and Geduldig v. Aiello, ${ }^{17}$ cases decided in the years immediately following Roe, the Court was faced with two classic instances of pregnancy discrimination in employment. LaFleur involved a mandatory maternity leave policy that forbade school teachers to work after their fourth or fifth month of pregnancy. Geduldig involved a state disability insurance plan that provided unemployment benefits for virtually all work-disabling physical conditions except pregnancy. The two policies exemplified the social judgment that pregnancy is incommensurate with employment, graphically illustrating the use of public power to transform the physiological act of gestation into a gendered condition of economic dependency. ${ }^{18}$ In both LaFleur and Geduldig, the lower courts struck down the sex-based regulation on equal protection grounds. ${ }^{19}$ In neither case did the Supreme Court follow their analysis. It invalidated the mandatory maternity leave policy in LaFleur because it embodied an irrebuttable presumption that violated requirements of due process, and it upheld the disability insurance exclusion in Geduldig as consistent with requirements of equal protection. ${ }^{20}$

The Court's equal protection analysis in Geduldig is by now infamous. ${ }^{21}$ The Court refused to recognize a classification based on pregnancy as sex-

16. 414 U.S. 632 (1974).

17. 417 U.S. 484 (1974).

18. The same is true of the policy in Turner v. Department of Employment Sec., 423 U.S. 44 (1975) (per curiam), which the Court decided following its holding in LaFleur. Turner concerned a Utah law making pregnant women ineligible for unemployment compensation for 12 weeks preceding and six weeks following the expected date of childbirth.

19. Aiello v. Hansen, 359 F. Supp. 792, 799 (N.D. Cal. 1973) (“[Much] of our society's vievrs concerning the debilitating effects of pregnancy are more of a response to cultural sex-role conditioning than a response to medical fact and necessity."), rev'd sub nom., Geduldig v. Aiello, 417 U.S. 484 (1974); LaFleur v. Cleveland Bd. of Educ., 465 F.2d 1184, 1188 (6th Cir. 1972) ("This record indicates clearly that pregnant women teachers have been singled out for unconstitutionally unequal restrictions upon their employment."), aff'd on other grounds, 414 U.S. 632 (1974).

20. See Geduldig, 417 U.S. at 494; LaFleur, 414 U.S. at 648.

21. See, e.g., Law, supra note 5, at 983-84 ("Criticizing Geduldig has since become a cottage industry. ... Even the principal scholarly defense of Geduldig admits that the Court was wrong in refusing to recognize that the classification was sex-based. ..."). 
based, insisting the disability exclusion did not "involv[e] discrimination based upon gender as such," 22 because "[t]he program divides potential recipients into two groups-pregnant women and nonpregnant persons. While the first group is exclusively female, the second includes members of both sexes."23 Although this approach to characterizing regulatory classifications was by no means compelled by precedent, ${ }^{24}$ the Court employed it without attempting to reconcile its holding with the concerns of equal protection doctrine. ${ }^{25}$ Instead the Court justified its refusal to recognize pregnancy regulations as sex-based state action for purposes of equal protection review with the observation that

[n]ormal pregnancy is an objectively identifiable physical condition with unique characteristics. Absent a showing that distinctions involving pregnancy are mere pretexts designed to effect an invidious discrimination against the members of one sex or the other, lawmakers are constitutionally free to include or exclude pregnancy from the coverage of legislation such as this on any reasonable basis, just as with respect to any other physical condition. ${ }^{26}$

At the simplest level, Geduldig's holding that pregnancy classifications are not sex-based can be criticized on physiological grounds. The Court ignored the fact that the capacity to gestate distinguishes the sexes physically. ${ }^{27}$ But, just as importantly, the Court ignored the fact that the capacity to gestate distinguishes the sexes socially: Judgments about women's capacity to bear children play a key role in social definitions of gender roles and thus in the social logic of "discrimination based on gender as such."

This critical perception is lacking in Geduldig. Because the Court viewed

22. Geduldig, 417 U.S. at 496 n.20.

23. Id.

24. Many regulatory classifications struck down on equal protection grounds do not pertain to an entire suspect class. For example, in Reed v. Reed, 404 U.S. 71 (1971), the Court invalidated a statute that designated persons entitled to administer an intestate's estate because it gave a preference to men where several persons were otherwise equally entitled. As the Court itself pointed out, "Idaho does not ... deny letters of administration to women altogether. Indeed, under $\$ 15-312$, a woman whose spouse dies intestate has a preference over a son, father, brother, or any other male relative of the decedent." Id. at 75 . The statute in Reed operated like the disability insurance program in Geduldig. The policy challenged in Reed denied administrator status to a particular class of women; the statute conferred administrator status on men and women both. Cf. Phillips v. Martin Marietta Corp., 400 U.S. 542 (1971) (treating an employer's refusal to hire women with preschoolage children as a sex-based policy for purposes of employment discrimination law).

The Court might easily have characterized the disability insurance program challenged in Geduldig as sex-based on the grounds that it discriminates between male and female employees who procreate, or that it discriminates between those employees who have the capacity to gestate and those who do not. See note 27 infra and accompanying text.

25. It is hard to see why concerns about bias that inform the proscription against sex-based state action would not be as urgent in the case of legislation that affects most women and no men as they are in the case of legislation that affects all women and no men.

26. Geduldig, 417 U.S. at 496 n.20.

27. Cf. General Elec. Co. v. Gilbert, 429 U.S. 125, 161-62 (1976) (Stevens, J., dissenting) (pregnancy exclusion is sex-based because "the capacity to become pregnant ... primarily differentiates the female from the male"); Geduldig, 417 U.S. at 501 (Brennan, J., dissenting) ("[D]issimilar treatment of men and women on the basis of physical characteristics inextricably linked to one sex, inevitably constitutes sex discrimination."). 
pregnancy as "an objectively identifiable physical condition," about which "reasonable," as distinct from "invidious," discriminations could be made, it required plaintiffs to prove that any pregnancy regulations they challenged were "mere pretexts" designed to accomplish some other discriminatory end. To be actionable as sex discrimination in this framework, a state's decision to provide employment insurance for all work-disabling conditions except pregnancy would have to reflect an abstract animus toward women as such - rather than, for example, a belief that a pregnant employee would not, or should not, remain in the work force, or that she would, or should, have someone to support her. Beliefs of this sort and the practices they make "reasonable" (such as denying pregnant women unempioyment insurance benefits) are part of the social relations of reproduction which define motherhood as a condition of economic dependency. Because the Court evaluated the exclusionary pregnancy policy in a framework that focused on the physical rather than social relations of reproduction, it could see that "[n]ormal pregnancy is an objectively identifiable physical condition with unique characteristics," but could not see that the state's pregnancy policy reflected and enforced social judgments about women's roles.

Despite changes affecting the treatment of pregnancy in employment discrimination law, the Court has continued to analyze reproductive regulation in physiological paradigms, interpreting the Equal Protection Clause in ways that suggest that regulation concerning pregnancy presents little possibility of sex discrimination. ${ }^{28}$

The physiological naturalism informing the Court's reasoning in Geduldig emerged again to shape the Court's analysis in Michael M. v. Superior Court. ${ }^{29}$ In this case, the Court upheld a statutory rape law against equal protection challenge, even though the statute criminalized only men's participation in an otherwise consensual act of sexual intercourse. Although ample historical evidence indicated that the law had been enacted to protect female chastity, the Court chose to evaluate it as if it had been enacted to prevent teenage pregnancy. ${ }^{30}$ Once the statutory rape law was analyzed as a

28. Two years after Geduldig, the Court applied the same reasoning to Gilbert, an employment discrimination case under Title VII of the Civil Rights Act of 1964, 42 U.S.C. $\$ \S 20002$ to 20002-17 (1988), again refusing to recognize regulation respecting pregnancy as sex-based. See Gilbert, 429 U.S. at 136 ("Geduldig is precisely in point in its holding that an exclusion of pregnancy from a disability benefits plan ... is not a gender-based discrimination at all."). This decision set off a controversy that prompted Congress to amend Title VII to make clear that distinctions on the basis of pregnancy are sex-based. See Pregnancy Discrimination Act of 1978, Pub. L. No. 95-555, § 1, 92 Stat. 2076, 2076 (codified at 42 U.S.C. $\$ 2000$ e(k) (1988)) ("The terms 'because of sex' or 'on the basis of sex' include, but are not limited to, because of or on the basis of pregnancy, childbirth, or related medical conditions ....".").

Despite these developments, the Court continued to construe the Equal Protection Clause in ways that suggested that regulation concerning pregnancy was not sex-based and presented little possibility of sex discrimination. See, e.g., Harris v. McRae, 448 U.S. 297, 322 (1980) (the Hyde Amendment restricting abortion funding "is not predicated on a constitutionally suspect classification"); Maher v. Roe, 432 U.S. 464, 470 (1977) (statute restricting abortion funding "involves no discrimination against a suspect class").

29. 450 U.S. 464 (1981).

30. Id. at 470 ("We are satisfied ... that the prevention of illegitimate pregnancy is at least one 
form of reproductive regulation, the sex distinctions in the statute found their legal justification in physical distinctions between the sexes. As Justice Rehnquist explained, "[w]e need not be medical doctors to discern that young men and young women are not similarly situated with respect to the problems and the risks of sexual intercourse. Only women may become pregnant and they suffer disproportionately the profound physical, emotional, and psychological consequences of sexual activity."31 A legislature was entitled "to punish only the participant who, by nature, suffers few of the consequences of his conduct" because "the risk of pregnancy itself constitutes a substantial deterrence to young females. No similar natural sanctions deter males."32 By this reasoning, pregnancy imposes "natural sanctions" on women, to which men "by nature" are immune. Men are therefore properly subject to the state's criminal law, which will " 'equalize' the deterrents" to sexual relations imposed on women by nature. ${ }^{33}$

The equal protection analysis offered in Michael $M$. takes the complex questions posed by a sex-based statutory rape law and reduces them to a problem that concerns women's reproductive physiology. A frank account of the normative concerns that might support the constitutionality of such a law would focus on the social conditions in which women conceive, bear, and rear children, not the physical fact that "[o]nly women may become pregnant."34 If a sex-based statutory rape law can be reconciled with values of equal protection, it is because the social relations of reproduction affect young women differently than they affect young men: Young women are vulnerable to types of coercion, stigma, and disadvantage in matters of sex and parenthood that young men do not face. ${ }^{35}$ Michael $M$. discusses these troubling aspects of gender relations as "natural sanctions" "suffer[ed]" by women, to which men, "by nature," are not subject-reasoning about gender inequalities as if they were immediate "consequences" of the physical facts of sex.

Because the Court does not discriminate between the physical and social relations of reproduction, it evaluates regulatory decisions about reproduction as if they were merely responses to the physical realities of reproduction, and thus can "realistically reflect[] the fact that the sexes are not similarly situated in certain circumstances."36 The naturalistic framework

of the 'purposes' of the statute ...."). But cf. id. at 494-96 \& nn.9-10 (Brennan, J., dissenting) (the history of statutory rape laws reveals that legislators were concerned with protecting teenage chastity, not preventing teenage pregnancy; the terms of the challenged statute suggest that it "was initially designed to further these outmoded sexual stereotypes"); see also Rita Eidson, Comment, The Constitutionality of Statutory Rape Laws, 27 UCLA L. REv. 757, 762-68 (1980).

31. Michael M., 450 U.S. at 471 (plurality opinion).

32. Id. at 473 .

33. Id.

34. Id. at 471.

35. Social analysis of a sex-based statutory rape law may support arguments for and against its constitutionality. Compare Wendy W. Williams, The Equality Crisis: Some Reflections on Culture, Courts, and Feminism, 7 WOMEN's RTS. L. REP. 175, 179-90 (1982) with Frances Olsen, Statutory Rape: A Feminist Critique of Rights Analysis, 63 TEx. L. REv. 387, $422-24$ (1984).

36. Michael M., 450 U.S. at 469 (plurality opinion). 
in which the Court reasons about reproductive regulation obscures questions concerning its normative content that would be the central focus of doctrinal inquiry if the Court recognized that reproductive regulation concerned matters of gender, and not merely physiological sex. The remarks of Justice Stewart illustrate this dynamic:

[W] hile detrimental gender classifications by government often violate the Constitution, they do not always do so, for the reason that there are differences between males and females that the Constitution necessarily recognizes. In this case we deal with the most basic of these differences: females can become pregnant as a result of sexual intercourse; males cannot.

... Gender-based classifications may not be based . . . upon archaic assumptions about the proper roles of the sexes. But we have recognized that in certain narrow circumstances men and women are not similarly situated; ... and a legislative classification realistically based upon those differences is not unconstitutional. ${ }^{37}$

No meaningful review of reproductive regulation is possible within this equal protection framework. Because the Court rarely acknowledges that reproduction is social as well as physiological, it systematically ignores what is evident as a matter of common sense: When a legislature adopts regulation governing the conditions in which women conceive, gestate, and nurture children, its actions are "realistically based upon" and thus "realistically reflect[]" social judgments about women's roles-and only secondarily, if at all, facts about their bodies. Regulations governing the conditions in which women conceive, gestate, and nurture children express social attitudes about sexuality and motherhood and, in turn, shape women's experience of sexuality and motherhood. Yet, to date, the Court has not scrutinized reproductive regulation to ascertain what gender-based judgments it might reflect or enforce. Analyzed within paradigms attentive to the physical rather than the social organization of reproduction, reproductive regulation is effectively immunized from critical constitutional review.

\section{B. Physiological Naturalism and Due Process: Roe v. Wade}

Though the Court has assumed a more aggressive role in reviewing reproductive regulation under constitutional doctrines of privacy, naturalistic assumptions about reproduction inform its due process jurisprudence as well. Roe v. Wade, decided a year prior to Geduldig, shares many of the analytic tendencies of Geduldig, although these tendencies have drawn less critical comment. This section identifies some of the ways in which physiological naturalism informed the Court's reasoning in Roe, affecting Roe's account of a woman's interests in abortion and the state's interests in its

37. Id. at 478 (Stewart, J., concurring) (citations omitted); $c f$. id. at 498 n.4 (Stevens, J., dissenting) ("In cases involving discrimination between men and women, the natural differences between the sexes are sometimes relevant ... . [1]f, as in this case, there is an apparent connection between the discrimination and the fact that only women can become pregnant, it may be appropriate to presume that the classification is lawful.").

38. 410 U.S. 113 (1973). 
regulation, as well as the account Roe provided of the history of abortion's criminalization.

\section{Roe's account of women's interests in abortion.}

Given the time and circumstances of authorship, Roe describes a woman's interest in terminating a pregnancy in an attentive and empathetic fashion. The opinion notes many factors that may cause women to seek an abortion. It recognizes that "[s]pecific and direct harm medically diagnosable even in early pregnancy may be involved" and that "[p]sychological harm may be imminent"; it further observes that "[m]aternity, or additional offspring, may force upon the woman a distressful life and future," that a woman's "[m]ental and physical health may be taxed by child care," and that pregnancy may result in a child a family is "unable, psychologically or otherwise, to care for" or "the additional diffculties and continuing stigma of unwed motherhood."39 The opinion suggests that, in making the decision whether to terminate a pregnancy, "[a]11 these are factors the woman and her responsible physician necessarily will consider in consultation." 40

Roe describes a woman's interest in terminating a pregnancy in terms consonant with the logic of the therapeutic exception, which was expanding at the time of the Court's decision. ${ }^{41}$ Consequently, the opinion presents decisions about motherhood as a private dilemma to be resolved by a woman and her doctor: a "woman's problem," in which the social organization of motherhood plays little part. ${ }^{42}$ In $R o e$, the Court repeatedly suggests that states should defer to private decisions respecting abortion because they reflect the expertise of a medical professional, ${ }^{43}$ not because the community

\section{Id. at 153.}

40. Id.

41. Therapeutic exceptions to criminal abortion statutes allowed physicians to perform legal abortions for specified medical reasons, most commonly to save a woman's life or health. See Model Penal CODE $§ 230.3$ (1962), cited in Roe, 410 U.S. at 140, reprinted in Doe v. Bolton, App. B, 410 U.S. 179, 205 (1973) (allowing a physician to terminate a pregnancy when "he believes there is substantial risk that continuance of the pregnancy would gravely impair the physical or mental health of the mother"). Similar statutes were adopted in a third of the states at the time of the decision. Roe, 410 U.S. at 140. For an account of the expansion of the therapeutic exception in the years preceding the Roe decision, see Herbert L. Packer \& Ralph J. Gampell, Therapeutic Abortion: A Problem in Law and Medicine, 11 STAN. L. REV. 417 (1959).

42. The Court's account scarcely mentions the social norms and practices that make maternity "distressful" for a woman. Only in noting "the additional difficulties and continuing stigma of unwed motherhood" does the Court acknowledge that the conditions of motherhood are socially defined, but it does so without giving any critical significance to that fact. Roe, 410 U.S. at 153 .

43. After deciding (in two paragraphs) that the right of privacy protects a pregnant woman's decision whether or not to bear a child, $i d$. at 152 , the Court refers throughout the remainder of the opinion to the right of privacy as a right shared by the physician and his patient, or as belonging to the physician alone, even though it dismissed the physician-plaintiff in the case for want of standing to sue. See id. at 123-29. Indeed, Roe consistently suggests that the decisions it protects and the judgment it empowers belong to doctors, not women, emphasizing that "the abortion decision in all its aspects is inherently, and primarily, a medical decision," and insisting that the opinion "vindicates the right of the physician to administer medical treatment according to his professional judgment." Id. at 165-66; see also id. at 163 ("[F] or the period of pregnancy prior to this 'compelling' point, the attending physician, in consultation with his patient, is free to determine, without regula- 
owes any particular deference to women's decisions about whether to assume the obligations of motherhood. Because Roe and its progeny treat pregnancy as a physiological problem, they obscure the extent to which the community that would regulate a woman's reproductive choices is in fact implicated in them, responsible for defining motherhood in ways that impose material deprivations and dignitary injuries on those who perform its work. Analyzed within a medical framework, exclusion from employment, ${ }^{44}$ denial of unemployment and health insurance benefits, ${ }^{45}$ the stigma of unwed motherhood, ${ }^{46}$ and other of pregnancy's "natural sanctions"47 appear as consequences of a woman's body-not practices of the community that would regulate her conduct. Roe's account of the abortion decision invites criticism of the abortion right as an instrument of feminine expedience (i.e. abortion "for convenience" or "on demand") 48 because it presents the burdens of motherhood as woman's destiny and dilemma-a condition for which no other social actor bears responsibility. ${ }^{49}$

tion by the State, that, in his medical judgment, the patient's pregnancy should be terminated."); Susan F. Appleton, Doctors, Patients and the Constitution: A Theoretical Analysis of the Physician's Role in "Private" Reproductive Decisions, 63 WASH. U. L.Q. 183, 197-207 (1985) (analyzing portrayal of physician as decisionmaker in Roe). The Court's repeated description of the abortion right as protecting a physician's decisions plainly bespeaks a distrust in women's competence to make reproductive decisions, whether that distrust of women was the Court's own or one it imputed to the public. See Marie Ashe, Law-Language of Maternity: Discourse Holding Nature in Contempt, 22 NEW ENG. L. REv. 521, 541-42 (1988) (privacy right recognized in abortion cases is located, not in pregnant woman alone, but in the relationship between the pregnant proman and the physician; doctrine defers to medical expertise rather than woman's judgment).

44. See Cleveland Bd. of Educ. v. LaFleur, 414 U.S. 632 (1974).

45. See General Elec. Co. v. Gilbert, 429 U.S. 125 (1976); Turner v. Department of Employment Sec., 423 U.S. 44 (1975); Geduldig v. Aiello, 417 U.S. 484 (1974).

46. Roe, 410 U.S. at 153 .

47. Michael M. v. Superior Court, 450 U.S. 464, 473 (1981) (plurality opinion).

48. See, e.g., Doe v. Bolton, 410 U.S. 179, 221-22 (1973) (White, J., dissenting in Roe and Doe) (referring disparagingly to abortions of "convenience" three times in four paragraphs, and observing that under the majority's holding the "Constitution of the United States values the convenience, whim, or caprice of the putative mother more than the life or potential life of the fetus").

49. Stripped of its therapeutic trappings, the Court's account presents abortion as the resort of women whose "woes, ... . emotions, ... frailty, so-called "error,' and needs," drive them to terminate unborn life. Doe, 410 U.S. at 196-97. So long as accounts of the abortion decision exempt men and society at large from their responsibility for shaping the conditions under which women conceive, bear, and rear children, it is only the woman seeking an abortion who appears to attach negative value to pregnancy. In these circumstances, her decision to seek an abortion will appear to reflect traits of the feminine character-be it frail, overwrought, selfish, or capricious.

Roe's account of the abortion decision is reinforced by the constitutional underpinnings of the opinion, which protect the right as a right of "personal privacy," applying to "activities relating to marriage, procreation, contraception, family relationships, child rearing and education." Roe, 410 U.S. at 152-53 (citations omitted). Because the concept of privacy grows out of traditions that assume the structure of family life as natural and accept the ideological division of social life into separate spheres for men and women, see Frances E. Olsen, The Family and the Market: A Study of Ideology and Legal Reform, 96 HARV. L. REV. 1497 (1983), it can be employed in ways that reinforce notions of pregnancy as a "woman's problem." Traditional assumptions about the structure of private life tend to inhibit critical examination of the social relations in which women conceive, bear, and rear children - an inquiry which would illuminate many of the practical reasons why women seek abortions, and provide additional constitutional reasons for protecting exercise of that choice. 


\section{Roe's account of state regulatory interests in abortion.}

The same medical paradigms that govern Roe's analysis of a woman's interest in terminating a pregnancy dominate its analysis of the state's interest in regulating her decision. Because Roe relies so heavily upon medical science to define the state's interest in regulating abortion, medical analysis displaces social analysis of the exercise of state power entailed in restricting women's access to abortion. For this reason, the interest in potential life recognized in Roe can be employed to justify fetal-protective regulation of women in a fashion that is inattentive to the gender-based impact of that regulation as well as to the possibility that it may be gender biased.

Roe justifies the state's interest in regulating abortion by adopting, quite explicitly, a purely medical definition of pregnancy:

The pregnant woman cannot be isolated in her privacy. She carries an embryo and, later, a fetus, if one accepts the medical definitions of the developing young in the human uterus. See Dorland's Illustrated Medical Dictionary $478-479,547$ (24th ed. 1965). The situation therefore is inherently different from [all other privacy precedents] $\ldots .50$

When the Court considers the pregnant woman from what it conceives to be a strictly physiological standpoint, in Roe, just as in equal protection cases like Geduldig, it sees her "situation [as] inherently different" from that of other citizens. ${ }^{51}$ The Court asserts that the pregnant woman's privacy rights are defeasible, without devoting a single sentence to explaining why this is so. The Court simply assumes that the existence of the embryo/fetus is sufficient to explain and justify the state's interest in regulating abortion; the opinion nowhere addresses the possibility that public interest in restricting abortion might be shaped by social judgments about the pregnant woman herself. As in its equal protection jurisprudence, the Court reasons from the premise that the physical reality of pregnancy can objectively substantiate public regulatory judgments concerning the pregnant woman. ${ }^{52}$

Consistent with the manner in which it justifies the state's interest in regulating abortion, Roe defines the circumstances in which the state may regulate abortion in terms of medical facts concerning gestation. The opinion's "trimester framework" allows the state to regulate abortion in the interests of maternal health in the second trimester of pregnancy, when mortality in abortion exceeds mortality in childbirth,,$^{53}$ and allows regulation

50. 410 U.S. at 159.

51. See Geduldig v. Aiello, 417 U.S. 484, 496 n.20 (1974) ("Normal pregnancy is an objectively identifiable physical condition with unique characteristics."); see also Michael M., 450 U.S. at 471 (plurality opinion).

52. Cf. text accompanying notes $36-37$ supra. Indeed, these objectivist assumptions are so pronounced that the Court subsequently describes the state's regulatory interest in maternal health and potential life as embodied in the progress of gestation itself, observing that these regulatory interests "grow[] in substantiality as the woman approaches term and, at a point during pregnancy, each becomes "compelling.' " Roe, 410 U.S. at 162-63. By this account, a pregnant woman nurtures more than fetal life. She nurtures within her body an interest of the community whose "growth" progressively consumes her claim on privacy and bodily autonomy.

53. "[B]ecause of the now-established medical fact ... that until the end of the first trimester 
in the interests of potential life in the third trimester of pregnancy, at the point of fetal viability. According to Roe, the concept of viability supplies "logical and biological justifications" for "[s]tate regulation protective of fetal life" because "the fetus then presumably has the capability of meaningful life outside the mother's womb."54

Roe thus holds that the state has an interest in potential life which becomes compelling at the point of viability. It defines this regulatory interest in potential life physiologically, without reference to the sorts of constitutional considerations that normally attend the use of state power against a citizen. In the Court's reasoning, facts concerning the physiological development of the unborn provide "logical and biological justifications" both limiting and legitimating state action directed against the pregnant woman. Because Roe analyzes an exercise of state power from a medical, rather than a social, point of view, it authorizes state action against the pregnant woman on the basis of physiological criteria, requiring no inquiry into the state's reasons for acting against the pregnant woman, or the impact of its actions on her. Indeed, Roe analyzes the state's interest in potential life as a benign exercise of state power for the protection of the unborn, and not as a coercive exercise of state power against pregnant women, often reasoning as if the state's interest in protecting potential life scarcely pertained to the pregnant woman herself. ${ }^{55}$ Thus, in the course of justifying its decision to protect the abortion decision as a right of privacy, the Court recognized an antagonistic state interest in restricting women's access to abortion on which it imposed temporal, but few principled, restraints. ${ }^{56}$

To the extent that Roe relied upon physiological reasoning to define the state's interest in potential life, it unleashed a legal discourse of indeterminate content and scope-one legitimating boundless regulation of women's reproductive lives should the Court abandon the trimester framework that presently constrains it. ${ }^{57}$ In recognizing the state's interest in potential life,

mortality in abortion may be less than mortality in normal childbirth, [i]t follows that, from and after this point, a State may regulate the abortion procedure to the extent that the regulation reasonably relates to the preservation and protection of maternal health." Id. at 163.

54. Id.

55. The Court discusses the state's interest in protecting a viable fetus as if the fetus were located in some hypothetical space outside the body of the woman in which it subsists. When the fetus is characterized as "presumably" capable of "meaningful life outside the mother's womb," $i d$., even as it remains within it, it appears as an autonomous object of public concern, justifying the Court's insistence that a state's regulatory interests in the pregnant woman and in potential life are "separate and distinct," id. at 162.

56. The restraints Roe imposes on the state's interest in potential life are temporal, pertaining to the physical development of the fetus, not the state's regulatory relation with the pregnant woman herself. Consequently, judgments about the fetus seem to determine the strength of a woman's privacy interests. (This is why medical advances affecting the point of fetal viability appeared to threaten the privacy right $R o e$ recognized. See note 57 infra.) If one removes the trimester framework from Roe, much of the opinion's reasoning seems to support, rather than constrain, abortionrestrictive regulation.

57. Initially, the manner in which the Court justified the state's interest in regulating abortion was of little practical significance to those exercising or defending the right Roe established because of the infrequency of third-trimester abortions. The nature of the state's regulatory interests in abortion was first called into question by now-discredited reports predicting the advance of viability into 
the Court ignored a simple social fact that should be of critical constitutional significance: When a state invokes an interest in potential life to justify fetalprotective regulation, the proposed use of public power concerns not merely the unborn, but women as well. Abortion-restrictive regulation is sex-based regulation, the use of public power to force women to bear children. Yet, the Court has never described the state's interest in protecting potential life as an interest in forcing women to bear children. Roe's physiological reasoning obscures that simple social fact. "[I]f one accepts the medical definitions of the developing young in the human uterus" 58 as a sufficient, objective, and authoritative framework for evaluating the state's regulatory interest in abortion-as Roe did-state action compelling women to perform the work of motherhood can be justified without ever acknowledging that the state is enforcing a gender status role. In part, this is because analyzing abortionrestrictive regulation within physiological paradigms obscures its social logic, but also, and as importantly, it is because physiological reasons for regulating women's conduct are already laden with socio-political import: Facts about women's bodies have long served to justify regulation enforcing judgments about women's roles.

\section{Roe's account of the history of abortion regulation.}

When the Court examined the history underlying the adoption of criminal abortion laws in nineteenth century America, it identified three reasons that might account for their enactment. The first was the notion that "these laws were the product of a Victorian social concern to discourage illicit sexual conduct."59 Observing that "no court or commentator has taken the

early gestation. Compare Akron v. Akron Ctr. for Reprod. Health, Inc., 462 U.S. 416, 456-58 (1983)

(O'Connor, J., dissenting):

Just as improvements in medical technology inevitably will move fonward the point at which the State may regulate for reasons of maternal health, different technological improvements will move backward the point of viability at which the State may proscribe abortions ... . The Roe framework, then, is clearly on a collision course with itself.

with Webster v. Reproductive Health Servs., 492 U.S. 490, 554 n.9 (1989) (Blackmun, J., concurring in part and dissenting in part) ("This ['collision course'] critique has no medical foundation.").

Today, it is crucial to understand the nature of the state's regulatory interests in abortion because an increasing number of sitting Justices have declared their dissatisfaction with the restraints the trimester framework imposes on the state regulation protective of potential life, see note 2 supra, and because lower courts are increasingly applying the trimester framework to fetal-protective regulation outside the abortion context. See, e.g., In re A.C., 533 A.2d 611 (D.C. Ct. App. 1987) (court orders the removal of a potentially viable fetus from a cancer patient by surgery that may have hastened her death), vacated, 573 A.2d 1235 (D.C. Ct. App. 1990) (en banc); In re Madyun Fetus, 114 Daily Washington L. Rep. 2233, 2240 (D.C. Super. Ct. July 26, 1986) (court orders a caesarean delivery over pregnant woman's objections, reasoning that "all that stood between the ... fetus and its independent existence was, put simply, a doctor's scalpel").

If the Court abandons Roe's trimester framework or qualifies a pregnant woman's privacy rights without imposing meaningful restraints on the interest in potential life Roe recognized, Roe will have spawned a constitutionally "compelling" interest in regulating the conduct of pregnant women that is elaborated in terms wholly inattentive to the social judgments prompting state action against the pregnant woman or the impact of state action on her.

58. Roe v. Wade, 410 U.S. 113, 159 (1973) (passage quoted in full in text accompanying note 50 supra).

59. Roe, 410 U.S. at 148. 
argument seriously,"60 the Court dismissed it without more, never again considering the possibility that sexual mores had anything to do with the statutes' enactment. A second rationale, to which it gave greater credence, was the theory that antiabortion statutes were adopted in order to restrict access to a procedure that at the time posed considerable dangers to a woman's health. ${ }^{61}$ Finally, the Court considered the contention that "a purpose of these laws, when enacted, was to protect prenatal life,"62 a view sharply contested by the litigants and one difficult to substantiate in light of the dearth of state legislative history from the nineteenth century. The Court left the question unresolved, but allowed "that as long as at least potential life is involved, the State may assert interests beyond the protection of the pregnant woman alone." 63 From its analysis of the historical record, the Court derived an account of the state interests that might legitimately be asserted in the regulation of abortion-all of which it assessed from the standpoint of medical science. In the course of this analysis, the Court never seriously considered the possibility that the state might have constitutionally illegitimate interests in regulating abortion.

It is important to examine the history of the nineteenth century campaign afresh, in order to understand how the abortion right is protected by constitutional guarantees of equal protection, as well as of privacy. ${ }^{64}$ The work of James Mohr, Linda Gordon, Kristin Luker, and Carroll Smith-Rosenberg provides a much more detailed account of the nineteenth century criminalization campaign than was available to the Court at the time of its decision. ${ }^{65}$ As importantly, historiographical and jurisprudential perspectives have changed in the years since Roe. Because we are now attentive to questions of gender in matters of historical and constitutional interpretation both, it is possible to reexamine the historical record and observe constitu-
60. Id.
61. Id. at $149-51$.
62. Id. at 151 (footnote omitted).
63. Id. at 150 .

64. Aspects of the historical record which are relevant to a due process analysis of the abortion right may not necessarily be those of relevance to the equal protection claim. While due process jurisprudence derives its moral authority from the rich traditions defining this nation's history, equal protection jurisprudence derives its moral authority from an aspiration to transcend certain aspects of that history so that the realities of American political life accord more fully with the ideals of American political life. Cf. Cass R. Sunstein, Sexual Orientation and the Constitution: $A$ Note on the Relationship Between Due Process and Equal Protection, 55 U. CHI. L. REv. 1161, 1171-76 (1988).

Roe is written as a substantive due process opinion, and draws its authority from the nation's history and traditions. The privacy right Roe recognized protects a liberty available to women at common law, and the state regulatory interests Roe recognized are those embodied in nineteenth century criminal abortion statutes, as the Court understood them. Because the Court crafted Roe as a due process opinion that would give synthetic expression to the nation's history and traditions, it never subjected the history of the criminalization campaign to critical scrutiny to determine whether in fact it deserved constitutional sanction.

65. See Linda GoRdon, WOMAN's BODY, WOMAN's RIGHT: A SOCIAL History OF BIRTH Control in AMERICA (1976); Kristin LUKER, Abortion AND the Politics of Motherhood (1984); JAMEs C. Mohr, Abortion IN AMERICA: The ORIGins aNd Evolution of National Policy, 1800-1900 (1978); CARRoll SMITH-ROSEnBerg, Disorderly Conduct: Visions OF GENDER IN Victorian AMERICA 217-44 (1985). 
tionally significant aspects of the campaign which the Court's naturalist assumptions caused it to overlook.

As the work of James Mohr and others makes clear, it was the medical profession that led the nineteenth century campaign to criminalize abortion. The doctors who advocated criminalizing abortion quite openly argued that regulating women's reproductive conduct was necessary, not merely to protect potential life, but also to ensure women's performance of marital and maternal obligations and to preserve the ethnic character of the nation. At the simplest level, then, the history of the criminalization campaign illustrates the wide-ranging social preoccupations that may inform public interest in regulating reproduction, among them, concerns rooted in relations of gender, ethnicity, race, and class. The history of the criminalization campaign demonstrates that reproductive regulation may indeed be driven by constitutionally illegitimate concerns, a possibility now obscured by the naturalist premises of equal protection and due process doctrines. Given the significant role that constitutionally offensive attitudes played in the nineteenth century campaign to criminalize abortion, it is important for courts reviewing fetal-protective regulation to determine whether it is animated by similar forms of bias today.

But the history of abortion's criminalization has other, more elusive, jurisprudential significance. The doctors who led the criminalization campaign advanced their arguments for regulating abortion in the distinctive discourse of their profession. They employed physiological arguments to demonstrate the impact of abortion, not only on the unborn, but also on the reproductive health and conduct of American wives and on the reproductive rates of various ethnic groups-thereby demonstrating that abortion threatened the allocation of power between men and women and among the various groups that might direct the future of the state. Physicians did not merely invoke the body as an analogical figure for the state. ${ }^{66}$ They used scientific arguments about the body to argue that controlling the physical relations of reproduction was necessary to ensure reproduction of the social order. ${ }^{67}$ Proponents of abortion reform thus corporealized the preoccupa-

66. Cf. Thomas Hobbes, Leviathan 81 (C.B. MacPherson ed., 1968) (1651):

For by Art is created that great LEVIATHAN called a COMMON-WEALTH, or STATE, (in latine CIVITAS) which is but an Artificiall Man; though of greater stature and strength than the Naturall, for whose protection and defence it was intended; and in which the Soveraignty is an Artificiall Soul, as giving life and motion to the whole body; The

Magistrates, and other Officers of Judicature and Execution, artificiall Joynts . . . .

See also John Locke, The Second Treatise of Civil Government $\|$ 96, at 55 (Thomas P. Peardon ed., 1952) (1764) ("For when any number of men have, by the consent of every individual, made a community, they have thereby made that community one body, with a power to act as one body, which is only by the will and determination of the majority ... and it being necessary to that which is one body to move one way, it is necessary the body should move that way whither the greater force carries it, which is the consent of the majority ....").

67. The campaign's use of reproductive paradigms to analyze social relations does bear certain striking resemblances to the work of Malthus (whom the doctors denounced, see note 135 infra) and his intellectual descendants, Herbert Spencer and Charles Darwin. Cf. RICHARD HorstadTER, Social Darwinism in American Thought 38-39 (The Beacon Press 1955) (1944) (tracing the legacy of Malthus's arguments through social and biological evolutionary theory); CHARLES E. Ro- 
tions of civic governance, imbuing the physiology of human reproduction with far-reaching social import. Because the mode of argument they employed grounds social relations in the physical process of reproduction, it imbues the raw facts of reproductive physiology with intrinsic sociality, transforming the female body itself into a "reason" for its regulation. In the wake of the campaign, it seems natural to reason about social relations in physiological terms; more particularly, it seems natural to reason about regulating women's roles in rhetorical paradigms concerned with women's bodies.

Thus, the criminalization campaign precipitated an important historical transformation, one affecting the practical means of regulating gender status and the rhetorical modes of its justification. This dimension of abortion's criminalization is invisible in Roe's account because, in important respects, Roe reasons within the premises of the legal regime it repudiated. Consequently, correcting the historical record on which Roe rests is a necessary first step in reconsidering the jurisprudence of abortion-restrictive regulation.

\section{The Nineteenth Century Campaign Against Abortion}

Woman's rights and woman's sphere are, as understood by the American public, quite different from that understood by us as Physicians, or as Anatomists, or as Physiologists. ${ }^{68}$

-Montrose H. Pallen, M.D. (1868)

The problem of woman's sphere, to use the modern phrase, is not to be solved by applying to it abstract principles of right and wrong. Its solution must be obtained from physiology, not from ethics or metaphysics . . . ${ }^{69}$

-Edward H. Clarke, M.D. (1873)

[S]ociety haunts the body's sexuality. ${ }^{70}$

- Maurice Godelier (1981)

Unlike the social historians who have explored the nineteenth century campaign to criminalize abortion in the years since $R o e,{ }^{71} \mathrm{I}$ approach the historical record with specific jurisprudential concerns. To demonstrate the inadequacies of doctrines that now govern reproductive regulation, I will

SENBERG, No OTHER GODS: ON SCIENCE AND AMERICAN SOCIAL ThOUgHT 33-34 (1961) (interest in the social significance of human heredity was growing in America prior to the spread of Darwinist thought). In these new nineteenth century traditions of political analysis, diverse aspects of the reproductive process begin to play a prominent role in explaining reproduction of the social order, displacing the role played by concepts of social contract in Enlightenment political theory. See notes 239-240 infra and accompanying text (examining the convergent concerns of the antiabortion campaign and evolutionary and eugenical thought in the post-Civil War period).

68. Montrose A. Pallen, Foeticide, or Criminal Abortion, 3 Med. ARChives 193, 205 (1869) (paper read before the Missouri State Medical Association, April, 1868).

69. Edward H. Clarke, SeX in Education, or A Fair Chance for Girls 12 (Boston, Houghton, Mifflin \& Co. 1873).

70. Maurice Godelier, The Origins of Male Domination, 127 New LEFr REv. 3, 17 (1981).

71. See, for example, the authors listed in note 65 supra. 
examine the concerns that have animated reproductive regulation in the past, and trace the lineage of physiological arguments for regulation of women's reproductive conduct. This analysis reveals that the conceptual paradigms we use to justify the regulation of reproduction have a history: They are aspects of the social relations of reproduction which enable us to reason about concerns of gender in physiological discourses of sex. As history amply demonstrates, claims about women's bodies can in fact express judgments about women's roles.

To illustrate this, I explore the antiabortion campaign from the standpoint of a practical historical question: Why were the arguments advanced by the nineteenth century medical profession successful in persuading the American public to criminalize one of the more effective methods of birth control of the era? After situating the criminalization campaign in social context, I consider two general strategies the campaign employed to persuade the public of the importance of regulating abortion.

Part II B examines the physiological arguments physicians used to demonstrate the practical threat abortion posed-to the unborn, to women, to the form and function of the marriage relation, and to the ethnic composition of the state. These physiological arguments focused wide-ranging concerns on the act of reproduction itself, so that protecting unborn life became a way of preserving the social structure as a whole. Part II $\mathbf{C}$ considers the more overtly gendered aspects of antiabortion advocacy, examining the campaign's arguments for regulating abortion as arguments for controlling women's conduct. Physicians regularly depicted abortion as an act of feminine role resistance, encouraged by feminist advocacy. In so doing, they invested abortion with symbolic meaning, urging Americans to oppose abortion in order to defend gender roles in diverse spheres of social life.

After surveying the wide-ranging concerns raised by the American Medical Association's antiabortion advocacy, I assess its immediate impact and long term legacy. Part II D discusses criminal abortion statutes adopted in the post-Civil War era, illustrating the influence of the doctors' arguments on legislative reform in Ohio. Part II E analyzes the criminalization campaign in wider legal perspective, as it offered a way to regulate gender roles that complemented the common law of marital status, providing the state with physiological justifications for enforcing wives' marital obligations.

Examining arguments for regulating abortion in times past provides no simple framework for scrutinizing its regulation today. But it does provide a foundation for undertaking that task, illuminating social concerns that are often obscured by the physiological habits of reasoning that the campaign engendered-and thus identifying new constitutional questions to which review of reproductive regulation must respond.

\section{A. Historical Context}

At the opening of the nineteenth century, abortion was governed by common law, and was not a criminal offense if performed before quickening- 
the point at which a pregnant woman perceived fetal movement, typically late in the fourth month or early in the fifth month of gestation. ${ }^{72}$ During the ensuing decades, especially in the years following the Civil War, states began to enact legislative restrictions on abortion. Although statutes varied in form and severity, the cumulative effect of the new legislation was to prohibit abortion from conception. The statutes proscribed abortion-without reference to quickening - unless necessary to save a mother's life, subjected women seeking abortions to criminal sanctions, and increased criminal penalties generally. States also adopted legislation barring the distribution of abortifacients and contraceptives, as well as the circulation of advertisements or information about them. ${ }^{73}$

This transformation in the law of abortion occurred at the behest of the nation's physicians-at once the architects and exponents of legal reform. In the early decades of the nineteenth century, when America's politicians, clergy, and press were silent on the question of abortion, the doctors began a concerted campaign, directed at fellow practitioners, legislators, religious leaders, and the public at large, to put abortion on the national political agenda. $^{74}$

As James Mohr has characterized it, the doctors" "opposition to abortion was partly ideological, partly scientific, partly moral, and partly practical."75 Doctors premised their campaign on a scientific understanding of human development as continuous from the point of conception, a scheme in which "quickening" had no special significance. With this understanding of human development and certain judgments about the nature of family life, doctors began to articulate strong moral objections to the practice of abortion, ${ }^{76}$ contending, as a matter of professional ethics, ${ }^{77}$ that abortion at any stage of pregnancy was an unwarranted destruction of human life.

72. The moment of quickening is variable. It is fair to say, however, that it is late enough in pregnancy such that the common law provided women a reasonable opportunity to secure a legal abortion. After quickening, persons who assisted in the expulsion and destruction of the fetus without due cause were considered to have committed a crime-one, however, distinct from the destruction of a human being, and punished less harshly. Roe v. Wade, 410 U.S. 113, 132-36 (1973); J. MoHR, supra note 65, at 3-6; see also id. at 5-6 nn.4 \& 5 (discussing American case law).

73. See J. MOHR, supra note 65 , at 200-25.

74. Abortion reform between 1820 and 1840 was typically undertaken in the course of code revisions, rather than by enactment of separate statutes. It was the product of medical advocacy, initiated without public, journalistic, or religious advocacy. Id. at 42-43. Religious leaders did not become involved in the crusade against abortion until after the Civil War, and then only hesitantly. See Carl N. Degler, At Odds: Women and the Family in America From the RevoluTION TO THE PRESENT 239 (1980); J. MoHR, supra note 65, at 182-88; John Paull Harper, "Be Fruitful and Multiply": The Reaction to Family Limitation in Nineteenth-Century America 154 (1975) (unpublished Ph.D. dissertation, Columbia University, on file with the Stanford Law Review); see also note 141 infra.

75. J. MoHR, supra note 65 , at 34-35.

76. Over the course of the campaign, doctors raised three types of moral objections to the practice of abortion. They vehemently insisted that the embryo was a form of human life whose destruction was tantamount to murder, see text accompanying notes 93-115 infra, that marital sexuality not devoted to procreating was a form of "physiological sin," see text accompanying notes 116136 infra, and that wives who shirked their duty to bear and rear children were self-indulgent egoists, see text accompanying notes 158-164 infra.

77. Mohr suggests that the physicians' allegiance to the Hippocratic Oath moved them to op- 
But, as Mohr points out, the doctors had practical, as well as moral and scientific, reasons for opposing abortion. The doctors inaugurated the campaign against abortion at a time when the medical profession was attempting to establish itself as a profession, and graduates of elite medical schools ("regulars") were attempting to drive competing popular practitioners ("irregulars") from the field. As the regulars saw it, their opposition to abortion distinguished them in method and commitment from all other health care providers of the era. By campaigning for legislative restrictions on abortion, the doctors were simultaneously entering the political arena on high moral ground, and seeking public power to close their ranks to professional competition. ${ }^{78}$

The competitive dynamic Mohr identifies underlying the campaign can in fact be described in sexual terms. The obstetricians and gynecologists who led the mid-century campaign against abortion were attempting to build a professional practice in a field traditionally dominated by women. At prominent institutions, doctors teaching obstetrics were still called "profes-

pose abortion. See J. MoHR, supra note 65 , at 35 . Before the inception of the campaign, however, it was not entirely clear that the ethical precepts of the physicians prohibited abortion.

At the outset, it should be noted that some versions of the Hippocratic Oath prohibit abortifacients (pessaries) only, while others prohibit the practice of abortion entirely, just as some versions of the Oath prohibit surgery, while others do not. See W.H.S. JONES, THE DocTOR's OATH $11,23,52$ (1924) (comparing Greek and Christian variants of Oath on question of abortion and surgery); see also Ludwig EdELSTEIN, THE Hippocratic OATH: TeXT, TRANSLATION AND INTERPRETATION 6-18, 24-32 (1943) (tracing Pythagorean sources of Oath's condemnation of abortifacients and surgery). More research is required to determine which versions of the Oath regulars employed during the antebellum period, or, indeed, whether, during this period, regulars systematically relied upon the Oath at all. American medical schools, then in their infancy, may well have administered the Oath, but the code of ethics the regulars most commonly relied upon was Percival's Medical Ethics, which the AMA explicitly cited as the source for the Code of Ethics adopted at its foundation in 1847. See Donald E. KonOLD, A History OF AMERICAN MEdiCAl ETHICS, 18471912, at 9-10 (1962); Percival's Medical Ethics 218 (Chauncey Leake ed., 1927). Percival's code condemns some but not all uses of abortifacients; in some passages it seems to accept the quickening distinction, and in others not to accept it. See id. at 134-36. The Code of Ethics the AMA adopted at its inception in 1847 and retained throughout the century does not address the question of abortion. See id. at 218-38.

Thus, in the years preceding the campaign, when abortions prior to quickening were still legal, the regulars' ethical stance toward the practice seems to have been less than uniform. $C f$. HeNRY Shafer, The American Medical. Profession, 1783 to 1850, at 222 (1968) (1st ed. 1936) (reporting that in the 1830s "[a]t least one [county medical] society considered [abortion] a violation of medical ethics"). If doctors did not openly endorse abortion, many among their ranks may well have practiced it. As James Mohr reports, campaign leadership had to quell resistance in the ranks of the profession before it took its case to the American public. See J. Mokr, supra note 65, at 14953, 156; see also The Report Upon Criminal Abortions, 56 Boston MED. \& SURGICAL J. 346, 346 (1857) ("Argue as forcibly as they may ... the Committee will fail to convince the public that abortion in the early months is a crime, and a large proportion of the medical profession will tacitly support the popular view of the subject.").

78. See J. MoHr, supra note 65, at 30-39; see also $\mathrm{K}$. LuKer, supra note 65, at 27-35; PAUL STARR, THE Social TRANSFORMATION OF AMERICAN MEDICINE 92 (1982) (explaining that the nineteenth century medical profession was competitive rather than corporate); $i d$. at 79-144 (tracing consolidation of professional authority from 1850 to 1930); BARBARA EHRENREICH \& DEIDRE ENGLISH, FOR HER OWN GOOD: 150 YeARS OF THE EXPERTS' ADVICE TO WOMEN 48-68 (1978) (chronicling competition faced by elite medical practitioners during nineteenth century); RICHARD SHRYOCK, THE DEVELOPMENT OF MODERN MEDICINE: AN INTERPRETATION OF THE SOCIAL AND SCIENTIFIC FACTORS INVOLVED 248-72 (1947) (same). 
sor of midwifery,"79 and practitioners often encountered skepticism and ridicule. $^{80}$ As late as 1881, a professional manual warned doctors to be on guard against "jealous midwives, ignorant doctor-women and busy neighbors" who spread malicious rumors about physicians. ${ }^{81}$ By opposing abortion, gynecologists and obstetricians hoped to establish their authority in matters of birthing, 82 and so improve their status in the eyes of the profession and the public at large. At a time when medical practitioners could do little to prolong life, the doctors' efforts to assert scientific authority over the inception of life enhanced the stature of the profession as a whole. ${ }^{83}$

79. For example, Horatio Storer, leader of the criminalization campaign, refers to his father as "the Professor of Midwifery in Harvard University." HORATIO RoBINSON STORER, WHY NOT? A Book For Every Woman 17 (Boston, Lee \& Shepard 1866). Similarly, Dr. Augustus Gardner, a prominent activist in the campaign, was titled "Professor of Diseases of Females and Clinical Midwifery" at New York Medical College. See Augustus K. Gardner, Conjugal Sins Against THE LAWS OF LIFE AND HEALTH 3 (photo. reprint 1974) (New York, J.S. Redfield 1870); Harpar, supra note 74 , at 100 .

A nineteenth century biographical sketch of the campaign's leader notes that Horatio Storer "was the first in this country to teach gynecology proper, as contra-distinguished from obstetrics or midwifery, his separate course upon the diseases of women, unconnected with gestation, childbed, or the puerperal state, comprising not less than sixty lectures." IRVING A. WATSON, PhySICIANS AND Surgeons of America: A Collection of BIographical Sketches of tHe Regular MediCAL Profession 25 (Concord, N.H., Republican Press Ass'n 1896).

80. The task of assisting a birth was traditionally handled by women. See JUDITH WALzER LEAVITT, BRought To BED: ChILDBEARING IN AMERICA 1750-1950, at 89-113 (1986) (role of gender in the birthing room). In the mid-nineteenth century when male doctors began to practice as birth assistants, they encountered both professional and popular objections, and often ridicule. See B. EHRENREICH \& D. ENGLISH, supra note 78, at 61-63 ("[b]y mid-century the private horrors of mixed-sex medical encounters had become a public issue"); JUDY BARRETT LITOFF, AMERICAN Midwives 1860 to THE PRESENT 3-14 (1978); C. SMITH-Rosenberg, supra note 65, at 231; Sarah Stage, Female Complaints: Lydia Pinkham and The Business of Women's MEDICINE 77-82 (1979) (public and professional criticism of clinical and surgical gynecologists); see also J.W. LEAVITT, supra, at 40-43, 108-10 (doctors style their procedures to accommodate patient modesty).

81. See P. STARR, supra note 78, at 87 (quoting professional manual by D.W. Cathell entitled The Physician Himself, published in 1881).

82. During the period of the criminalization campaign and after, the medical profession sought to establish its authority in matters of birthing by subordinating women's role in it. Doctors sought to eliminate midwives or redefine their work as physicians' assistants in all cases save those of the poorest clientele. They also sought to prevent women from joining their professional ranks. See notes 149 \& 153 infra. Notwithstanding these efforts, midwife-attended births exceeded physicianattended births until the beginning of the twentieth century, when they were about equal in numbers. See B. EHRENREICH \& D. ENGLish, supra note 78, at 93; J.W. LEAVITT, supra note 80, at 12; Frances E. Kobrin, The American Midwife Controversy: A Crisis of Professionalization, in Srckness and Health in America: Readings in the History of Medicine and Public Health 217, 219 (Judith Walzer Leavitt \& Ronald L. Numbers eds., 1978).

83. By opposing abortion, the profession could save unborn life, even if obstetricians and other regular practitioners were not markedly more adept than their competitors in saving the life of born persons. See K. LUKER, supra note 65, at 30-31; cf. J. MoHR, supra note 65, at 31-34 (discussing the inability of the practice to cope with common diseases of the era; professional physicians "really could not do what they claimed they could do"); id. at 34 ("[T] he regulars bitterly opposed what they regarded as quack theories, though in truth many of the irregulars advocated courses of treatment less detrimental to health than the regulars' own.").

During the nineteenth century the safety record of male obstetricians as measured by mortality statistics was no better, if not worse, than that of midwives. Physician intervention in birthing may actually have increased its dangers, given the doctors' proclivity for "heroic interventions": bloodletting, administering opiates, and using forceps during parturition. See B. EHRENREICH \& D. ENGLISH, supra note 78, at 97; J.W. LEAVITT, supra note 80, at 43-57, 62-63. In 1912, a medical study 
The doctors began their campaign quietly, working with legislators engaged in reforming state codes. ${ }^{84}$ It was not until the middle of the century that they took their campaign to the public. Until then, abortion had been considered the last resort of the desperate single woman. ${ }^{85}$ By mid-century, however, abortion was commonly perceived as a practice of married women seeking to avoid dangerous pregnancies and to control family size-a matter of special concern to middle-class families in the new industrial order. As middle-class families began to adopt increasingly elaborate methods for raising and educating children, parents began to consider children as work rather than workers, expense rather than wealth. ${ }^{86}$ With this transformation in child-rearing practices, the birthrate in America steadily declined. ${ }^{87}$ Abortion now appeared to play an increasingly significant role in efforts to control family size, more so among the middle class than among the immigrant working class. 88

Doctors advocating criminalization of abortion thus seized an issue of

reported doctors lost more patients than midwives. See Kobrin, supra note 82 , at 218. These statistics are especially noteworthy in that, by the turn of the century, midwives were primarily serving only the poorer sectors of society. B. EHRENREICH \& D. ENGLISH, supra note 78, at 93-98; J.B. LrTOFF, supra note 80, at 27-30. Whether women were served by doctors or midwives, they faced significant physical dangers in childbirth. Maternal mortality in childbirth apparently remained constant from 1890 to 1917. In 1917, it still caused more deaths among women than any disease except tuberculosis. Id. at 53.

84. See J. MoHR, supra note 65 , at $42-43$; id. at 43 (surveying statutory reform of the period and concluding that "[t]he United States remained in 1841, notwithstanding an initial wave of abortion legislation, a nation still committed to the basic tenets of the common law tradition").

85. See id. at 86. In fact, special laws which made it a crime to conceal the birth or death of bastard chlddren governed acts of abortion and infanticide practiced by unmarried women. Penalties for concealment were of moderate severity (typically 1 to 2 years of hard labor); they applied to abortion (without regard to quickening) and to infanticide. In this way, the statutes both condemned and condoned abortion and infanticide of illegitimate children. While some of the statutes dated from the colonial era, New York only adopted such a statute in 1845, along with general criminal abortion legislation. Act of May 13, 1845, ch. 260, $\$ \$ 4-5,1845$ N.Y. Laws 285, 286. See also 1 THEODORE ROMEYN BECK \& JOHN B. BECK, ElEMENTS OF MEDICAL JURISPRUDENCE 58689 (Philadelphia, J.B. Lippincott \& Co. 12th ed. 1863) (discussing state statutes); Eugene Quay, Justifiable Abortion, 49 GEO. L.J. 447, app. (1961) (reproducing state statutes governing concealment of bastard issue and abortion).

Consistent with this tradition, the leader of the criminalization campaign characterized infanticide, abandonment, or other similarly covert acts as the practice of the single woman, and abortion as the practice of the married woman. See H.R. STORER, supra note 79, at 67-68.

86. On the changing character of the parent-child relation in mid-century middle-class families, see MARY P. RYAN, CRADLE OF THE MIDDLE CLASS: THE FAMILY IN ONEIDA COUNTY, NEW YoRr, 1790-1865, at 155-85 (1981); Viviana A. Zelizer, Pricing the Priceless Child: The Changing Social Value of ChILdREN 5-6 (1985) (comparing shifting valuation of children in middle- and working-class families during the period of industrialization). See also C. DEGLER, supra note 74, at 72-85; C. RosENBERG, supra note 67 at 59; Nancy Schrom Dye \& Daniel Blake Smith, Mother Love and Infant Death 1750-1920, 73 J. AM. HIST. 329, 337-46 (1986).

87. See ANsley Coale \& Melvin Zelnik, New Estimates of Fertility and PopulaTION IN THE UNITED STATES: A STUDY OF ANNUAL WhITE BIRTHS FROM 1855 TO 1960 AND OF COMPLETENESS OF ENUMERATION IN THE CENSUSES FROM 1880 To 1960, at 36 (1963) (the rate at which white women in U.S. gave birth fell $50 \%$ between 1800 and 1900); id. at 38 (graph indicating birthrate declines throughout the century, with rate of decline accelerating in the 1840 s and again during the Civil War).

88. Mohr suggests that

abortion rates in the United States may have risen from an order of magnitude approximat-

ing one abortion for every twenty-five or thirty live births during the first three decades of 
intersecting professional, familial, and societal significance and made it a text of America's future. By 1859, medical opponents of abortion had secured a resolution from the American Medical Association (the "AMA") condemning abortion as an "unwarranted destruction of human life," and, under the leadership of Horatio Storer, ${ }^{89}$ elite physicians launched an aggressive public campaign dedicated to saving the nation from the evils of abortion. 90

These sociological observations explain the public visibility of abortion in mid-century America, as well as the medical profession's interest in curbing its practice. Yet, they do not illuminate how the AMA persuaded a public interested in limiting family size and inclined to defer to women's authority in matters of reproduction to criminalize one of the most reliable methods of birth control of the era. ${ }^{91}$. Indeed, at the advent of the campaign, one skepti-

the nineteenth century to an order of magnitude possibly as high as one abortion for every five or six live births by the 1850 s and 1860 s.

J. MoHR, supra note 65, at 50; see also C. DEGLER, supra note 74, at 228-32 (discussing contemporary reports of abortion); J. MoHR, supra note 65, at 82 (same); id. at 98-99 (after 1840, abortion used as means of family limitation nationwide); R. Sauer, Attitudes to Abortion in America, 1800 1973, 28 PopUlation STUd. 53, 54-56 (1974).

Dr. Horatio Gibbons, a contemporary observer, linked the increasing incidence of abortion to changing middle-class family norms:

As the children of the poor grow up, they become sources of revenue to the parents, who find their interest in an unrestricted increase. Whereas, the children of the better classes

... are a source of increased expenditure. Hence one of the strongest inducements to feticide in married women, is wanting in the humblest walks of life.

H. Gibbons, Sr., On Foeticide, 21 PAC. MEd. \& SurgiCal J. 97, 101 (1878); see also J. Mohr, supra note 65 , at 94-95, 100-02 (discussing evidence that in mid-nineteenth century abortion was most prevalent amongst the ranks of married, Protestant, economically privileged women).

89. Horatio Storer was the son of Dr. David Humphreys Storer, a professor of obstetrics and medical jurisprudence at Harvard University and a president of the AMA. Horatio Storer served as secretary of the AMA in 1865, and as its vice-president in 1868. During this period, he led the department of obstetrics and medical jurisprudence at Berkshire Medical College, where he distinguished himself as "the first in this country to teach gynecology proper, as contra-distinguished from obstetrics or midwifery" and, along with two other physicians, "came to monopolize the ovariotomies of the United States and Canada." I. WATson, supra note 79, at 25. For Storer's role in leading the antiabortion campaign, in the AMA and in the nation at large, see J. MoHR, supra note 65 , at $78,89,148-49,152-59,187,190,206-07$.

90. See Horatio R. Storer, Thomas W. Blatchford, Hugh L. Hodge, Edward H. Barton, A. Lopez, Charles A. Pope, William Henry Brisbane \& A.J. Semmes, Report on Criminal Abortion, 12 TRANSACTIONS AM. MED. AsS'N 75 (1859). On the lobbying campaign leading to adoption of the 1859 resolution, see J. Mokr, supra note 65, at 148-57 (transformation of physicians' crusade against abortion from an ad hoc movement to an organized national campaign); C. SMITH-ROSENBERG, supra note 65 , at 221-22.

91. According to James Mohr, contraceptive information was widely disseminated in the U.S. from the 1830s onward, and some of the techniques advocated were "partially effective even by modern standards." J. MoHR, supra note 65, at 83 . Potional and surgical abortion practices antedated this era, see id. at 6-15, 50-70, and, Mohr suggests, their use was increased by growing reliance on contraceptive methods, as families turned to abortion to "erase" mistakes produced by contraceptive failure. See id. at 84; see also 1 T.R. BECK \& J. BECK, supra note 85, at 477-95 (discussing potional and surgical abortion methods of the era). In this era, "natural" methods of contraception were especially likely to have failed because the medical profession identified the period half-way between the onset of menses as the so-called "safe period" for couples interested in avoiding conception. Thus, medical guidance in family planning would seem to have unintentionally increased the number of undesired pregnancies. See C. DEGLER, supra note 74, at 213-15; Thomas Laqueur, Ongasm, Generation, and the Politics of Reproductive Biology, 14 REPRESENTATIONS 1, 25-31 (1986) (medical profession analyzed ovulation in women with reference to dogs, analogizing menstruation to heat and thus identifying this period as the period of ovulation). 
cal physician observed that abortion was commonly relied upon as a method of family limitation, and confidently predicted that doctors would "fail to convince the public that abortion in the early months is a crime."92 To understand the campaign's success in cultivating popular opposition to abortion, it is necessary to examine the wide-ranging arguments doctors marshalled against the practice.

\section{B. The Doctors' Arguments: The Order of Life}

The arguments doctors brought to bear against the practice of abortion defined life from the perspective of medical science. The role of scientific argument is obvious in the profession's attack on the concept of quickening, which doctors criticized on the grounds that gestational development begins at conception. But other scientific arguments were offered as well. Doctors employed reproductive physiology to show how abortion affected the unborn, the institution of marriage, and affairs of state. These physiological arguments worked in complementary fashion, enabling physicians to portray abortion as a threat to the life of society as a whole.

\section{Maternal/fetal relation.}

When Dr. Montrose Pallen presented the argument for criminalizing abortion to fellow practitioners at the Missouri State Medical Association in 1868, he stated the physicians' case in succinct terms: 'Many persons scarcely recognize the fact that foeticide is murder of an unborn being, whether the conception have quickened, or at any period anterior to the quickening. Physiology teaches us that life is manifest as soon as the ovum is impregnated ...."93 The doctors employed a scientific account of conception to attack the idea of quickening; they sought to discredit the common law's understanding of gestational life, which deferred to the testimony of a pregnant woman, ${ }^{94}$ and to replace it with a definition of life that deferred to the authority and perspectives of medical science. ${ }^{95}$ Their defense of the

92. The Report Upon Criminal Abortions, supra note 77, at 346.

93. Pallen, supra note 68 , at 195.

94. The common law of abortion deferred to the woman as the responsible agent in reproduction in two notable respects. First, the doctrine of quickening defined life on the basis of the sensations and testimony of the pregnant woman. Second, despite the fact that common law rules of marital status made the wife a dependent of her husband, requiring his consent for her to engage in many transactions of consequence, it did not condition the legality of an abortion on his consent. See note 242 infra.

95. Horatio Storer impugned the common law doctrine of quickening with a three-fold observation: "quickening . . . is often absent, even throughout pregnancy; and foetal movements are sometimes appreciable to the attendant when not to the mother, or, indeed, they may be to the mother alone." Horatio R. STORER \& Frankin FISKE HEARD, CRIMINAL ABORTION: ITS NATURE, ITS EVIDENCE, AND ITS LAW 12-13 (Boston, Little, Brown \& Co. 1868). Quickening was unreliable evidence, which at times was undetectable and at other times better discerned by the doctor than his patient. Furthermore, it was evidence a woman could conceal. In deriding the concept of quickening, doctors thus attacked the sensations, judgments, and testimony of the pregnant woman. The conception standard doctors advocated vested the medical profession with authority to determine the beginning of life, depriving women of control over public determinations of that fact. 
conception standard advanced both objectives, offering a new way of reasoning about reproduction dramatically at odds with traditional understandings.

In arguing that life begins at conception, physicians proudly rejected theories of ensoulment as "metaphysical speculation."96 They sought to define life from the standpoint of medical science, in purely biological terms. Their arguments against abortion emphasized that the fertilized egg had a physiological capacity for growth, and derived from this capacity for growth the embryo's status as an autonomous life form. Thus, in defending the claim that life begins at conception, physicians redefined the maternal/fetal relation, offering a physiological account of human development that treated women's role in reproduction as a matter of minor consequence-from the point of conception onwards.

The distinctive perspective from which the profession attacked abortion is evident in arguments Jesse Boring offered colleagues at the Atlanta Medical Society in 1857. Denouncing the doctrine of quickening, Boring invited his colleagues to consider the embryo from a physiological standpoint:

[F]rom the moment of the fecundation of an ovum, it is, in every essential sense, a living, self-sustaining, and self-developing being, entitled to protection in its possessions, and that whatever it may become, physically, mentally, and spiritually, in utero, or extra-utero, is, by growth and development of the original, and not by addition of new materials, or attributes, and, therefore its destruction . . . is alike murder, at any and every stage of its existence . . . .97

Analyzed from a physiological standpoint, Boring contended, intrauterine life was its potential, already everything it might become in its extrauterine existence because it was capable of physical development. Boring gave this capacity for development particular moral weight. The fecundated ovum was "entitled to protection in its possessions"98 against the woman bearing it, not because it was vulnerable to or dependent upon her, but instead because its capacity for growth demonstrated it possessed the essential attribute of human life: autonomy. Boring saw evidence of the embryo's

96. Consider this legislative appeal by the Medico-Legal Society of New York:

The foetus is alive from conception, and all intentional killing of it is murder. The world is free to discuss the transcendental problem concerning the stage of development at which the foetus becomes endowed with a soul. Some may believe, with Plato, that this event is deferred till birth. Others may hold, with Aristotle, that is occurs at the fortieth day for boys and the eightieth for girls! Only, let such opinions have their due place and weight. Whatever may be their value as evidences of intellectual activity, they have no bearing whatever on the great practical question of child murder.

Report of THE COMMITTEe on CRIMINAL ABortion of THE Medico-Legal SOCIETY OF NEW YoRK (Dec., 1871), quoted in Cyril C. Means, Jr., The Law of New York Concerning Abortion and the Status of the Foetus, 1664-1968: A Case of Cessation of Constitutionality, 14 N.Y. L.F. 411, 47677 (1968) (emphasis omitted); see also H. STORER \& F.F. HEARD, supra note 95, at 14 ("We set aside all the speculations of the metaphysicians regarding moral accountability of the foetus, the 'potential man,' . . . as useless as they are bewildering.").

97. J. Boring, Foeticide, 2 Atlanta MEd. \& Surgical J. 257, 259 (1857).

98. Id. 
autonomy not only in its physical capacity for development but also in its physical relation to the pregnant woman:

[T] he fecundated ovum is not only the embryonic man, already vital, but it is, in an important sense, an independent, self-existent being, that is having in itself the materials for development, being actually separated from the mother, as well as from the father, though maintaining a connexion in utero by the vascular arrangement repeatedly referred to; there is, really, as has been fully demonstrated, no actual attachment of the placenta to the uterus. ${ }^{99}$

Physiologically considered, the "embryonic man" had the capacity to develop without the mother, a capacity for "self-sustaining" existence, proof of which lay in its lack of "actual attachment" to her. Boring thus defended the claim that life begins at conception with an argument that life developed by autogenesis.

When Horatio Storer addressed the nation's women in Why Not?, ${ }^{100}$ an antiabortion tract written for the AMA, he defended the conception standard in terms calculated to command the sympathies of his female audience. Instead of presenting the fertilized egg as an "embryonic man," he invited women to consider the embryo as a suckling infant. But this concession to maternal sympathy was merely superficial. Like Boring, Storer made no claims about the dependency of the unborn; instead, he rested his argument for protecting unborn life on the grounds of its physiological autonomy. The "unimpregnated egg "may perhaps be considered as a part and parcel of [a woman]," Storer explained, "but not afterwards."

When it has reached the womb, that nest provided for the little one by kindly nature, it has assumed a separate and independent existence, though still dependent upon the mother for subsistence. For this end the embryo is again attached to its parent's person, temporarily only, although so intimately that it may become nourished from her blood, just as months afterwards it is from the milk her breasts afford. ${ }^{101}$

In this curious image of embryo-as-suckling infant, Storer discerned proof of the embryo's "separate and independent existence."102 The analogy transported the embryo in time and space so that it appeared to be outside of the mother, thus illustrating the embryo's autonomy. Storer defended the "truth" of this analogical argument by offering another, based on the reproductive physiology of kangaroos. Like the embryo-as-infant argument, the kangaroo analogy situated the unborn outside the woman bearing it:

This is no fanciful analogy; its truth is proved by countless facts. In the kangaroo, for instance, the offspring is born into the world at an extremely early stage of development ... and then is placed by the mother in an external, abdominal, or marsupial pouch, to portions of which corresponding, so far as function goes, at once to teats and to the uterine sinuses, these em-

99. Id. at 266.

100. H.R. STORER, supra note 79.

101. Id. at 30 .

102. Id. 
bryos cling by an almost vascular connection, until they are sufficiently advanced to bear detachment, or in reality to be born. ${ }^{103}$

The polemical import of Storer's analogies was plain: “The first impregnation of the egg, whether in man or in kangaroo, is the birth of the offspring to life; its emergence into the outside world for wholly separate existence is, for one as for the other, but an accident in time."104

The arguments physicians employed to discredit the doctrine of quickening offered a dramatically new account of the maternal/fetal relation. Whereas tradition and common law both viewed the unborn as "part and parcel" of the pregnant woman, ${ }^{105}$ the physicians worked systematically to dismantle that view. They portrayed the unborn as an autonomous form of life, discussing the embryo's capacity for growth as if it could be exercised without the womb, and confusing categories of time and space so that unborn life seemed to have scant relation to the woman bearing it. Thus, as Storer reasoned, birth was "but an accident in time," 106 as insignificant as distinctions between the interior and exterior of women's bodies. No important difference existed between a gestating fetus and a suckling infant, or for that matter between an embryo and a grown man, because unborn life possessed its essential characteristics, even its "potentiality" for intellectual and moral reasoning, from the moment of conception. ${ }^{107}$

Yet, the doctors' most powerful strategy for demonstrating the autonomy of unborn life did not require confusing the facts of human development; it worked by focusing upon them selectively. The doctors rested their case that life begins at conception on "objective," but objectively incomplete, facts about human development, depicting the developmental process in ways that obscured the physical and social work of reproduction women perform. Thus, Hugh Hodge traced the path of human maturation without once referring to women's role in reproduction when he invited his audience to imagine the fertilized ovum developing into the highest form of social life-a fully matured man:

[T] he invisible product of conception is developed, grows, passes through the embryonic and foetal stages of existence, appears as the breathing and lovely infant, the active, the intelligent boy, the studious moral youth, the adult man, rejoicing in the plenitude of his corporeal strength and intellectual powers, capable of moral and spiritual enjoyments, and finally, in this world, as the aged man .... ${ }^{108}$

James Whitmire depicted human genesis similarly when he contended that, as a man of science, he could discern the present potentiality of a mature adult in the unfertilized ovum ("germ"):

103. Id. at $30-31$.

104. Id. at 31.

105. See id. at 30 (quoted in text accompanying note 101 supra).

106. H.R. STORER, supra note 79 , at 31 .

107. See note 112 infra.

108. Hugh Hodge, Foeticide, or Criminal Abortion 35 (Philadelphia, Lindsay \& Blakiston 1869), quoted in C. SMITH-ROSENBERG, supra note 65, at 242. 
Many, indeed, argue, that the practice [of abortion] is not, in fact, criminal, because, they argue, that the child is not viable until the seventh month of gestation, hence there is no destruction of life. The truly professional man's morals, however, are not of that easy caste, because he sees in the germ the probable embryo, in the embryo the rudimentary foetus, and in that, the seven months viable child and the prospective living, moving, breathing man or woman, as the case may be. ${ }^{109}$

In advancing their objections to abortion, physicians offered the American public a scientific way of reasoning about the genesis of life that systematically discounted women's role in reproducing life. ${ }^{110}$

The doctors' antiabortion arguments rested on a coherent account of human genesis, reflecting the belief that women's role in reproduction was a kind of reflexive physiological function. Just as doctors' antiabortion arguments regularly employed physiological evidence to identify the unborn with mature social actors, they employed that same discourse to identify women with the functions of their reproductive organs. ${ }^{111}$ Physiologically considered, unborn life was innately social, ${ }^{112}$ having a multiplicity of developmental ends and possibilities, whereas a woman had but one social end, dictated by her body. ${ }^{113}$ Women's reproductive organs were the active agents in re-

109. James S. Whitmire, Criminal Abortion, 31 CHI. MED. J. 385, 392 (1874). Whitmire, like Hodge, depicts the path of human development without referring to the agency, work, or existence of women. Similarly, when Horatio Storer addressed the nation's legislators in Criminal Abortion: Its Nature, Its Evidence, and Its Law, he emphasized the "total independence" of fetal life, insisting that "its subsequent history after impregnation is one merely of development, its attachment merely for nutrition and shelter" and buttressed his case once again by analogy to marsupial life. $\mathrm{H}$. STORER \& F.F. HEARD, supra note 95, at 10-11.

110. The fact that these new scientific objections to abortions focused on the fetus and ignored women's role in reproduction was perceived by at least one medical critic of the physicians' arguments. In 1857, just before the AMA inaugurated the antiabortion campaign, a doctor denounced a report of the Suffolk District Medical Society, criticizing the arguments it offered in defense of the conception standard:

The writer . . . seems to have thrown out of consideration the life of the mother, making that of the unborn child appear of far more consequence, even should the mother have a dozen dependent on her for their daily bread. It cannot be possible that either the profession or the public will be brought to this belief. Argue as forcibly as they may, .... the Committee will fail to convince the public that abortion in the early months is a crime, and a large proportion of the medical profession will tacitly support the popular view of the subject.

The Report upon Criminal Abortions, supra note 77, at 346 (criticizing committee report of the Suffolk District Medical Society, chaired by Storer).

111. Thus, even as Whitmire's case against abortion employed physiological reasoning to identify unborn life with developmentally mature persons, see text accompanying note 109 supra, it employed physiological reasoning to identify women with their bodily functions: "Gestation being a physiological condition, what woman could possibly be in a healthier state than when she is performing one of the greatest and noblest physiological functions of her being? Abortion, from whatever cause produced, is a pathological condition, and its results are pathological . . . ." Report upon Criminal Abortion, supra note 77, at 391; see also H.R. STORER, supra note 79, at 80-81 (quoted in text accompanying note 129 infra).

112. Cf. H. STORER \& F.F. HeARD, supra note 95, at 14 ("If there be life, then also the existence, however undeveloped, of an intellectual, moral, and spiritual nature, the inalienable attribute of humanity is implied.").

113. See, e.g., text accompanying note 129 infra. The profession was fascinated by a woman's reproductive organs, to which it traced what it perceived as the defining characteristics and debilities of the feminine nature. One doctor stated that it was as if "the Almighty, in creating the female sex, 
production; women were merely the passive instruments of nature's purposes, their agency appearing only as they interfered with the purposes nature intended for their bodies. As H.S. Pomeroy warned: "Interference with Nature so that she may not accomplish the production of healthy human beings is a physiological sin of the most heinous sort, for, from a physical standpoint, reproduction is the first and foremost aim and object of Nature . . . ."114

While the account of human genesis the doctors presented was internally coherent, it was dramatically at odds with the norms and practices of childrearing prevailing in mid-nineteenth century America. During this era, the parent who served as primary childrearer shifted from father to mother, and methods of childrearing shifted from discipline to character formation, a process which required meticulous maternal supervision of child development. By mid-century these changes in family norms assumed the pronounced forms popularly associated with the "cult of domesticity" or "separate spheres tradition."11s Thus, doctors justifying the conception standard emphasized the developmental autonomy of the unborn at a time when cultural authorities, including the medical profession itself, insisted that women's conduct in gestating and nurturing a child was the single most important determinant of its welfare. In defending the conception standard, doctors reasoned as if mother and child were scarcely related, trivializing acts of maternal nurturance otherwise urgently emphasized. In short, their account of human genesis contradicted, almost point for point, the norms and practices of reproduction prevailing during the era of the antiabortion campaign. In retrospect, it appears that if the medical profession did persuade nineteenth century audiences to think of the embryo/fetus as an autonomous life form, it was by encouraging Americans to take for granted the work of gestation and nurturance women perform-work which the "cult of domesticity" defined as a woman's duty to perform.

had taken the uterus and built up a woman around it." Carroll Smith-Rosenberg, The Female Animal: Views of Woman and Her Role in Nineteenth Century America, 60 J. AM. HISr. 332, 335 (1973) (quoting M.L. Holbrook, Parturition Without Pain: A Code of Directions For Escaping From the Primal Curse (New York, Wood \& Holbrook 1874)); T. Gaillard Thomas, Abortion and ITs TReatment, From the STAND-PoINT of Practical Experience 3 (New York, D. Appleton \& Co. 1890) ("The uterus is a most extraordinary part of the female economy. It is the organ which divides one sex from the other .... From thirteen to fifty its career is one of intense activity, and it has a marked influence upon the whole being of the woman."); see also B. EhrenREICH \& D. ENGLISH, supra note 78, at 120-26; JoHN S. HALlER, JR. \& RobIN M. Haller, The Physician and Sexuality in Victorian AMERICA 58-61 (1974); C. SMITH-RoSENBERG, supra note 65, at 183-96; Laqueur, supra note 91, at 2-3 (tracing emergence of scientific paradigms premised on a view of male and female reproductive organs as incommensurable, displacing traditional view of male and female reproductive organs as homologous).

114. H.S. Pomeroy, The Ethics of Marriage 97 (New York, Funk \& Wagnalls 1888).

115. For an examination of changes in parenting, and of practices and prescriptive norms pertaining to gestation, breast-feeding, and childrearing from infancy to adolescence during this period, see, e.g., C. DEGLER, supra note 74, at 72-85; C. ROSENBERG, supra note 67, at 26-29, 58, 68; M. RYAN, supra note 86, at 157-63; MARY P. RYAN, WOMANHOOD IN AMERICA From Colonial. Times to THE PRESENT 98-101 (3d ed. 1983); Dye \& Smith, supra note 86, at 337-46. 


\section{Marriage.}

In attacking the quickening doctrine, doctors described human development in ways that obscured women's role in reproduction, but their arguments against abortion by no means neglected the maternal role. Antiabortion tracts repeatedly asserted that women had a duty to bear children. This duty to reproduce entailed more than an obligation to protect particular embryos and fetuses; it was a duty that derived, implicitly or explicitly, from the obligations of marriage. Doctors attacked both abortion and contraception as violations of marital obligation, and, to prove this, emphasized the danger they posed to women's health. In elaborating these physiological objections to birth control practices, the medical profession redefined marital obligation in therapeutic terms.

As the doctors repeatedly asserted, the purpose of marriage was to perpetuate the species. Any effort to interfere with this purpose amounted to what Pomeroy called "physiological sin"116_a concept that fused the two forms of cultural authority doctors used to indict birth control practices. Thus, in 1870 Augustus Gardner published a tract entitled Conjugal Sins, ${ }^{117}$ which condemned, as linked and like evils, masturbation, contraception, and abortion. Two years later, William Goodell offered his students at the University of Pennsylvania a lecture on this procreative ethic entitled On Conjugal Onanism and Kindred Sins, ${ }^{118}$ which sought to demonstrate the diseases attributable to the interruption of intercourse. "It does indeed seem to be the law of Nature that man must suffer the punishment of the onanist if he parts with the 'seed of another life' in any other way than in that by which it tends to become fruitful," he observed, but "[t]he wife suffers the most, because she both sins and is sinned against. She sins because she shirks those responsibilities for which she was created. She is sinned against, because she is defrauded of her [conjugal] rights ...."119 The terms of this ethic defined all nonprocreative sexuality as licentious sex. It was for this reason that when America's first laws against contraception were enacted in the years after the Civil War, they classified information concerning contraception and abortion as "obscene."120

116. H.S. POMEROY, supra note 114, at 97 (quoted in full at text accompanying note 114).

117. A. GARDNER, supra note 79.

118. William Goodell, Clinical Lecture on Conjugal Onanism and Kindred Sins, PHILA. MED. TIMES, Feb. 1, 1872, at 161 .

119. Id. at 162 ; see id. at 163 ("[I]n common with other teachers, I am old-fashioned enough to believe that pregnancy is a necessary condition to healthful and happy marriages, and, further, that coition is innocuous only when complete in both husband and wife and when the germinal fluid bathes her reproductive organs."). Goodell's exposition is intriguing for its endless play on the reproductive dimensions of "conjugal rights." See, e.g., id. at 162; see also L.F.E. BERGERET, THE Preventive Obstacle, or Conjugal ONANisM (photo. reprint 1974) (P. De Marmon trans., 3d ed., New York, Turker \& Mingard 1870) (clinical case histories of women suffering diseases attributed to conjugal onanism).

120. See, e.g., Act of Apr. 28, 1868, ch. 430, 1868 N.Y. Laws 856 ("An Act for the suppression of the trade in and circulation of obscene literature, illustrations, advertisements, and articles of indecent or immoral use, and obscene advertisements of patent medicines"). On federal and state legislation prohibiting the use of the mails to transmit information or articles pertaining to contraception and abortion as obscenity, see C. Thomas DienNes, LAw, Politics, AND BirTh CoNTrol 
The doctors made little effort to conceal the religious sources of this pronatalist ethic. Yet, while physicians freely invoked biblical authority to condemn nonprocreative sexuality as $\sin ,{ }^{121}$ they most frequently spoke as physiologists, emphasizing the many diseases which issued from any effort to defeat the procreative purposes of marital sexuality. Thus, doctors elaborated a norm of marital sexuality in therapeutic terms, ${ }^{122}$ and in doing so, they defined women's health as a condition of continuous reproductive activity. ${ }^{123}$ In his popular antiabortion tract Why Not?, Storer lectured his audience: "Intentionally to prevent the occurrence of pregnancy, otherwise than by total abstinence from coition, intentionally to bring it, when begun, to a premature close, are alike disastrous to a woman's mental, moral, and physical well-being." 124 Of course, many Americans disagreed: Women who understood that childbearing and childrearing could compromise their physical, social, economic, and psychological "well-being" were increasingly willing to employ birth control practices. The physicians' arguments that contraception and abortion were "alike disastrous to a woman's mental, moral, and physical well-being" must be read, as they were argued, against that fact. ${ }^{125}$ In the criminalization campaign, the profession employed the

20-48 (1972); Michael Grossberg, Governing The Hearth: LAW aND the Family IN NiNeTEENTH-CENTURY AMERICA 175-93 (1985); J. MOHR, supra note 65, at 200-25; James C.N. Paul, The Post Office and Non-Mailability of Obscenity: An Historical Note, 8 UCLA. L. Rev. 44 (1961); Harper, supra note 74, at 179-209.

121. See, e.g., D.A. O'Donnell \& W.I. Atlee, Report on Criminal Abortion, 22 Transactions AM. MED. Ass'N 239, 240 (1871) (quoted in full at note 127 infra); see also J.M. Toner, Abortion in its Medical and Moral Aspects, 5 Communications 443, 443 (1861):

No law of nature can be violated without punishment being inflicted upon the offender, both morally and physically. If God punished Onan by death for spilling his seed upon the ground, how much more fearful will be his vengeance upon the person who not only destroys the fructifying seed but the life of a new human being?

122. See, e.g., H.R. STORER, supra note 79, at 61 ("the prevention of pregnancy, by whatever means it may be sought, by cold vaginal injections, or by incomplete or impeded sexual intercourse, is alike destructive to sensual enjoyment and to the woman's health"); Bibliographical Notes, 53 BOSTON MED. \& SURGICAL J. 410, 411 (1856) (arguing that when "impregnation [is] prevented ... in any way, .... the termination of ... naturally aroused uterine excitement, which fails of its legitimate end, [will result] in congestion, inflammation and final disorganization").

123. Horatio Storer translated this norm into practical terms:

Every married woman, save in very exceptional cases, which should only be allowed to be such by the decision of a competent physician, every married woman, until near the socalled turn of life, should occasionally bear a child; not as a duty to the community merely ... but as the best means of insuring her own permanent good health. How frequently should this be? Usually the interval should be from two to two and a half or three years, so as to allow a sufficient time for nursing, so important for the welfare of the child and its mother, and an interval of subsequent rest.

HORATio ROBINSON STORER, Is IT I?, A BOOK FOR EVERY MAN 115-16 (photo. reprint 1974) (Boston, Lee \& Shepard 1868). Similarly, Edwin Hale characterized contraception as an "offence ... against physiology, because it prevents the occurrence of pregnancy, which is a normal physiological condition, and often absolutely necessary to the physical and moral health of woman." Edwin M. Hale, The Great Crime of the Nineteenth Century 6n (Chicago, C.S. Halsey 1867). He makes the same argument against abortion. Id. at 5; see also note 119 supra and accompanying text.

124. H.R. STORER, supra note 79 , at 76 .

125. John Harper observes that when physiological arguments against contraception first appeared in the mid-1850s, they were greeted with skepticism by many in the medical profession, and, apparently, lacked any empirical substantiation. See Harper, supra note 74, at 86-89. Harper cites 
authority of medical science to define a norm of health powerful enough to oppose and contain expressions of women's reproductive will. ${ }^{126}$

The concept of "physiological sin" thus enfolded old authority within new, using religion and science to define the obligations of marriage in reproductive terms. The AMA's 1871 Report On Criminal Abortion claimed that the procreative purposes of marital sex could be deduced from "certain impresses ... stamped on the character of both male and female by which they are brought together," 127 and then denounced the woman who aborted a

sources suggesting that Storer opposed contraception because he was concerned about the falling "native birth rate," id. at 87, and for this reason used physiological arguments to deter women from practicing birth control, see id. at 87-88. By the 1860 s claims of reproductive degenerescence, buttressed by anecdotal case histories, were commonplace in the literature. See text accompanying notes 116-124 supra. There were, however, some physicians who denounced such claims as "myth." Harper, supra note 74, at 216; see id. at 215-26 (dissenting physicians advocating contraception); $c f$. J. HALlER \& R. HALLER, supra note 113, at 114-15 (discussing coitus interuptus), 122-24 (discussing concerns underlying medical profession's opposition to contraception).

Harper also points out that while doctors publicly insisted on the danger abortion posed to women's health, they privately discussed the procedure-under the rubric of "inducing premature labor"-as relatively safe. See Harper, supra note 74, at 103-04, 139-40, 213-15 (citing doctors of the era); see also J. MoHR, supra note 65, at 30-31 (suggesting, contrary to the thesis of Cyril Means, Means, supro note 96 , that abortion during this period was no more dangerous than childbirth, and may have been safer).

The rhetoric of certain clinical discussions makes clear that the profession analyzed the health risks of abortion from rather pronounced normative premises. See, e.g., E.P. Christian, The Pathological Consequences Incident to Induced Abortion, 2 Detrort REv. MED. \& PhaRMacy 145, 146 (1867) (citing "the intimate relation between the nervous and uterine systems manifested in the various and frequent nervous disorders arising from uterine derangements," i.e., "hysteria," and "the liability of the female, in all her diseases, to intercurrent derangements of these functions" as factors that "might justly lead us to expect that violence against the physiological laws of gestation and parturition would entail upon the subject of such an unnatural procedure a severe and grievous penalty"). The rhetoric of popular antiabortion tracts was even more pronounced. See note 126 infra.

126. In Why Not?, Storer observes, "[i]t is generally supposed, not merely that a woman can wilfully throw off the product of conception without guilt or moral harm, but that she can do it with comparative impunity as regards her own health." H.R. STORER, supra note 79, at 36 . Storer then introduces his discussion of the health risks attending abortion with the observation that "any infringement of [natural law] must necessarily cause derangement, disaster, or ruin." Id. at 36-37.

Other doctors were even more direct. "It is ... women who do not pretend to guide the course of events, or make the laws of nature conform to their wishes, who are in health," Augustus Gardner warned, "while the wise in their own conceit are sufferers, invalids, and useless." Augustus Gardner, Physical Decline of American Women, reprinted in A. GARDNER, supra note 79, at 199, 230. Similarly, Edwin Hale condemned the wife who seeks an abortion for "love of fashionable life," warning "[s]terility comes to punish her for the heinous crime of which she has been guilty. ... . [A]bortion brings sickness and perhaps death, or numerous other evils in its train, besides remorse, which will come sooner or later." E. HALE, supra note 123, at 10; see also id. at 9 "In natural, healthy parturition, there is little or no actual pain. ... Abortion, on the contrary, is always attended by a great amount of immediate or remote suffering.").

One commentator associated abortion, infanticide, masturbation, and contraception with the women's rights movement, and characterized all five as impulses that would result in sterility. See 3 Arthur W. Calhoun, A Social history of the American Family From Colonial Times TO THE PRESENT 245 (1919); cf. Margarette J. Sandelowski, Failures of Volition: Female Agency and Infertility in Historical Context, 15 SigNs 475, 480-86 (1990) (physicians of the era advance idea that female volition is an explanation of sterility).

127. O'Donnell \& Atlee, supra note 121, at 240.

God's first commandment to Adam and Eve in the garden of Eden was, to increase and multiply. . . : and so solicitous was he in carrying out his divine object, that certain impresses were stamped on the character of both male and female by which they are brought 
pregnancy: "She becomes unmindful of the course marked out for her by Providence, she overlooks the duties imposed on her by the marriage contract. She yields to the pleasures-but shrinks from the pains and responsibilities of maternity ...."128 The campaign's leader, who preferred to speak "purely" as a physiologist, made the same point when he warned the nation's women:

Were woman intended as a mere plaything, or for the gratification of her own or her husband's desires, there would have been need for her of neither uterus nor ovaries, nor would the prevention of their being used for their clearly legitimate purpose have been attended by such tremendous penalties as is in reality the case. ${ }^{129}$

Because the compound concept of "physiological sin" derived a wife's duties from facts about her body, it empowered doctors, rather than husbands, with special authority in questions concerning a wife's conduct. The physician was to serve as his patient's "confessor"130 and "physical guardian." As Storer explained to the nation's legislators, "medical men are the physical guardians of women and their offspring; from their position and peculiar knowledge necessitated in all obstetric matters to regulate public sentiment, and to govern tribunals of justice."131 Claiming public authority in "all obstetric matters," the medical profession asserted that it had special competence to mediate between a woman and the state, thereby appropriating a role the common law otherwise defined as the husband's. This claim of expertise justified the so-called "therapeutic exception" to birth control laws, which made the woman a ward of her physician, whose judgments governed her legal access to abortion and contraception. ${ }^{132}$ With this medical definition of the marriage relationship, a woman's choices regarding birth control were made subject to a man's consent, where no such requirement existed at common law before. ${ }^{133}$

At the same time that doctors asserted professional authority over a wife's reproductive conduct, they insisted upon the public character of that conduct. A wife had a duty to bear children which she owed, not to her

\footnotetext{
together, and to purify that union and to render intact and without reproach the parents and their offspring, the institution of matrimony was established. Id.

128. Id. at 241.

129. H.R. STORER, supra note 79 , at $80-81$.

130. See id. at 18 ("physician's consulting room proving in reality a confessional, wherein, under the implied pledge of secrecy and inviolate confidence, the most weighty and at times astounding revelations are daily made"); see also id. at 34, 52, 62.

131. H. STORER \& F.F. HEARD, supra note 95, at 4; see also Christian, supra note 125, at 146; Storer et al., supra note 90, at 76 ("We are the physical guardians of women; we, alone, thus far, of their offspring in utero.").

132. See H. STORER \& F.F. HEARD, supra note 95, at 104 (advocating therapeutic exception to criminal abortion statutes); see also H.R. STORER, supra note 123, at 115-16 (suggesting that any abatement of reproductive activity should occur only at the advice of physician); note 219 infra.

133. The common law of marital status required a husband's consent for a wife to engage in many legal and economic transactions. By contrast, common law doctrines pertaining to abortion and marital status imposed no requirement that a wife obtain a husband's consent in order to secure an abortion. See note 242 infra.
} 
husband, but to the community: It was "a duty [she] tacitly promised the State."134 Laws against abortion and contraception were necessary to protect the public's interest in procreation. Synthesizing religious, medical, and common law authority in neo-Malthusian ${ }^{135}$ terms, the doctors argued that the institution of marriage was of the utmost public regulatory concern because it was responsible for the production of populations, and in the production of populations lay the welfare of the state. ${ }^{136}$

\section{The state.}

The campaign defined intimate aspects of "private" life as matters of intense public regulatory interest, not merely by expanding the concept of deviant sexuality to include all nonprocreative marital sex, but also by depicting marital sex as an activity involving the production of citizens. In the medical profession's arguments against abortion, family and state did not stand in traditional, homologous relation to each other. ${ }^{137}$ Doctors described family and state as interdependent institutions, arguing that regulation of private conduct was necessary to preserve the character of public life.

In nearly all antiabortion tracts, doctors emphasized that abortion was most frequently practiced by married women, particularly those of the socalled "native" middle class. Abortion did not simply threaten the unborn; it threatened unborn populations. ${ }^{138}$ When, for example, James Whitmire argued that "the truly professional man ... sees in the germ the probable

134. D.H., On Producing Abortion: A Physician's Reply to the Solicitations of a Married Woman to Produce a Miscarriage for Her, 17 NASHville J. MED. \& SURGERY 200, 201 (1876):

If you are not willing to accept the cares, labors, responsibilities, and duties, of married life, why did you enter into that state? You were not forced into it; but you voluntarily and deliberately assumed that relation, and now you have no right to attempt to escape from what you knew beforehand is one of its most natural consequences, and a duty you tacitly promised the State, by whose authority you legally came together as husband and wife, you would perform.

See also H.R. STORER, supra note 123, at 115-16 (describing childbearing as a "duty to the community").

135. See H. STORER \& F.F. HEARD, supra note 95, at 9 n.1, 62 (attacking Malthus).

136. D.M. Reese put the physicians' case succinctly:

[A]s marriage is a civil contract, the fruits of which vastly concern the public welfare, bearing as they do on the present and future generation, it is the duty of the State, in every civilized and Christian country, to surround marriage with all the sanctions of law, and to protect the unborn fruits of such alliances from premature destruction by statutory enactments. These should be such as enlightened science and philanthropy suggest, and should be encouraged and reinforced by the united power of religion and the law.

D. Meredith Reese, Infant Mortality in Large Cities; The Sources for its Increase, And Means for its Diminution, 10 TraNSACTIONS AM. MED. Ass'N 91, 101-02 (1857).

137. Cf. William Gouge, Of Domesticall Duties (1622) ("a familie is a little Church, and a little commonwealth, at least a lively representation thereof, whereby triall may be made of such as are fit for any place of authoritie, or of subjection in Church or commonwealth"), quoted in John Demos, The LiTtLe Commonwealth: Family LIFE In Plymouth ColonY 1 (1970); HeMAN HUMPHREX, DOMESTIC EduCATION 16 (1840) ("Every family is a little state, or empire within itself, bound together by the most endearing attractions, and governed by its patriarchal head, with whose prerogative no power on earth has a right to interfere."), quoted in ANTEBELLUM AMERICAN Culture: AN INTERPRETIVe ANThology 10 (David Brion Davis ed., 1979).

138. The first chapter of Criminal Abortion, Storer's major work of medical jurisprudence on the subject, condemns abortion on the ground that life begins at conception, while the second chap- 
embryo [and] in the embryo . . . the prospective living, moving, breathing man or woman," the prospective man or woman he had in mind was apparently of his own social class, for, without pause, Whitmire identified abortion as

one great cause and reason for so few native-born children of American parents, according to the number of young married people, and in comparison with those of other nationalities among us. . . . This, too, is one of the many reasons why we are fast losing our national characteristics, and slowly merging into those of our foreign population, who, according to the United States statistics of 1870 , are rearing fifty per cent. more children according to their number than Americans are doing. ${ }^{139}$

The refrain was repeated in one tract after another. ${ }^{140}$ Augustus Gardner dedicated Conjugal Sins "To the Reverend Clergy of the United States who by example and instruction have the power to arrest the rapid extinction of the Native American People."141

The physicians thus depicted reproductive conduct as public, urging middle-class audiences to repudiate practices of abortion and contraception in order to preserve the political power of their social class. To this end, the doctors self-consciously translated the relations of political governance into reproductive terms. Dr. H.S. Pomeroy observed: "[I] $]$ is coming to pass that our voters-and so our lawmakers and rulers, indirectly, if not directlycome more and more from the lowest class, because that class is able and willing to have children, while the so-called better classes seem not to be."142

ter offers lengthy statistical analyses of who in the community is aborting, broken down by national and socioeconomic backgrounds. See H. STORER \& F.F. HEARD, supra note 95, at 15-64.

Similarly, Edwin Hale defined abortion as a crime, first because "[i]t lessens the population of a State or country, in an appalling degree," second because "it is a crime against physiology," third because "it is a crime against morality," and lastly because "it is a crime against the law." E. HALE, supra note 123, at 4-6. He then observed that "[e]ven ovular abortion, or the prevention of conception, may . . . be considered in the light of an offence against the State . . . because it prevents the normal increase of population, and against physiology, because it prevents the occurrence of pregnancy ...." Id. at $6 \mathrm{n}$.

139. Whitmire, supra note 109 , at 392.

140. Dr. Andrew Nebinger summarized an article from Harper's Monthly Magazine on the relative population rates of "original native stock" and "foreign population" in New England, arguing "that this non-production of offspring on the part of Americans . . . is the result mainly of the practice of criminal abortions." ANDREW NEBINGER, CRIMINAL ABORTION; ITS EXTENT AND Prevention 6-7 (Philadelphia, Collins 1876); see also 3 A. CALHoun, supra note 126, at 236 (quoting Dr. Nathan Allen to the effect that the "growth and prevalence of the practice of abortion" was partly responsible for the "decline of productiveness among native New Englanders"), 225-54 (chapter on "Race Sterility and Race Suicide" quoting doctors and other social observers on the causes and social implications of the declining birth rate of so-called "native" Americans, and containing much medical commentary on abortion); Pallen, supra note 68, at 198-99.

141. A. GARDNER, supra note 79, at 5. On the reticence of the nation's clergy to join the antiabortion campaign, see J. MoHR, supra note 65, at 182-96; see also id. at 195-96 "The origins and evolution of anti-abortion attitudes in the United States owed relatively little to the influence or the activities of organized religion."); id. at 167 ("There can be little doubt that Protestants' fears about not keeping up with the reproductive rates of Catholic immigrants played a greater role in the drive for anti-abortion laws in nineteenth-century America than Catholic opposition to abortion did.").

142. H.S. POMEROY, supra note 114 , at 39. 
In his succinct adage, "preform lies back of reform."143 Similarly, in Why Not? Storer lectured his female audience about the larger political implications of abortion:

All the fruitfulness of the present generation, tasked to its utmost, can hardly fill the gaps in our population that have late been made by disease and the sword, while the great territories of the far West, just opening to civilization, and the fertile savannas of the South, now disinthralled and first made habitable by freemen, offer homes for countless millions yet unborn. Shall they be filled by our own children or by those of aliens? This is a question that our own women must answer; upon their loins depends the future destiny of the nation. ${ }^{144}$

Translating the creed of manifest destiny into reproductive terms, Storer fused America's populations, territories, and women in a powerful image of reproductive potentiality. The nation's fate now depended on the "loins" of "our own women," whose refusal to reproduce threatened it with miscegenous decay. ${ }^{145}$ In this vision, the state was its populations, and its identity was determined by the reproductive conduct of its female citizens. Political power resided in control of those citizens who would bear citizens.

By attacking abortion on physiological grounds, the doctors channeled wide-ranging social concern into the act of reproduction itself. The claim that life begins at conception provided a persuasive basis for criminalizing abortion, as one of many arguments that identified the reproductive process as the basis of social life. Taken together, the import of these claims was clear: Regulating the physical act of reproduction was necessary to ensure reproduction of the social order. As various members of the profession expressed it, the incidence of abortion was a "leprosy upon the body politic,"146 a "foul sore in the body politic,"147 a "constitutional disease . . . poisoning the blood and distilling its venom into every fiber of the body politic."148 It thus followed that to protect "life"-be it the unborn, the "health" of America's wives, or the political power of the "native" American classes-it was necessary to wrest from women control over decisions respecting reproduction. The arguments employed by the profession to per-

\section{Id. at 34:}

In a republic all civil reform must have its roots in reform of the individual and the family. Tracing a reform back to its source, we find that an officer of the law carries out the orders of the executive, the executive carries out the provisions of the law, the law is an expression of the will of the Legislature, the Legislature is elected by the voter, and the voter's will is usually the expression of his birth and home training. And so we may trace reform back to the nursery. I shall endeavor in these pages to show that reform may be traced still farther back, or, rather, that preform lies back of reform.

144. H.R. STORER, supra note 79 , at 85 ; see also H. STORER \& F.F. HEARD, supra note 95 , at 41-53 (analyzing relative birthrates of "native" American and immigrant populations in Massachusetts).

145. See note 239 infra and accompanying text (discussing relation of mid-century campaigns against abortion and miscegenation).

146. Pallen, supra note 68, at 195.

147. H.R. STORER, supra note 79, at 35.

148. Gibbons, supra note 88 , at 97. 
suade the public of the necessity of regulating abortion were arguments about the necessity of controlling women.

\section{The Doctors' Arguments: The Disorder of Life}

The antiabortion campaign repeatedly insisted that women's reproductive conduct demanded regulation, using arguments which are striking in their rhetorical range and tenor. These arguments provide ample evidence that the campaign itself was the product of sexual conflict reaching far beyond the question of abortion.

To some extent the doctors' attacks on women can be explained in parochial, professional terms. During the period of the criminalization campaign, the gynecologists and obstetricians of the AMA were seeking to appropriate management of the birthing process from midwives, and to prevent women from entering the medical profession. ${ }^{149}$ At the same time, they were struggling to build a practice of female patients, and so were peculiarly subject to the market demands of women, many of whom were interested in procuring services that doctors refused to provide. ${ }^{150}$ These socio-economic concerns informed the physicians' case against abortion, leading them to depict the practice of abortion as a female conspiracy requiring male intervention. ${ }^{151}$ For example, Storer and Heard's treatise Criminal Abortion ${ }^{152}$ discussed the perpetrators of abortion by sex. It identified them, in order of culpability, as the pregnant woman, her female friends and acquaintances, nurses, midwives and female physicians - then husbands, quacks and professed abortionists, and druggists, but rarely, if ever, male physicians in regular standing. ${ }^{153}$ Others joined Storer and Heard in depicting abortion as a

149. See G.J. Barker-Benfield, The Horrors of the Half-Known Life: Male ATtiTUDES TOWARD WOMEN AND SEXUALITY IN NINETEENTH-CENTURY AMERICA 61-62, 84-85, 8788, 255 (1976); B. EhreNREICH \& D. ENGLISH, supra note 78, at 54-61; J. MoHR, supra note 65, at 168-69; P. STARR, supra note 78, at 47-51, 117, 124; Dara Clapper Brack, Displaced-The Midwife by the Male Physician, in WOMEN LOOK AT BIOLOGY LOOKING AT WoMEN: A Collection OF Feminist CRITIQUes 83, 90-95 (Ruth Hubbard, Mary Sue Henifin \& Barbara Fried eds., 1979); see also J. LEAVITT, supra note 80, at 87-115 (role of gender in the birthing room during the nineteenth century).

150. See E. HALE, supra note 123, at 14:

[T] he honorable physician who refuses to accede to the wishes of such patrons, is often obliged to see their patronage transferred to other and less scrupulous persons. ... [S] [ transfer of patronage is a growing evil which needs to be abated by some influence-moral, religious, or legal-which is not now in operation.

See also K. LUKER, supra note 65, at 37 (physicians who turned away patients who requested abortions might lose those patients to other practitioners); J. MoHR, supra note 65, at 37 ("as the regulars themselves pointed out, it was not so much the short-term loss of a fee for the abortion that upset them, but the prospects of a long-term loss of patients").

151. See C. SMITH-RosenBERG, supra note 65, at 231-36.

152. See note 95 supra. Jurists often cited this treatise as an authoritative commentary on abortion in the latter half of the nineteenth century. See Harper, supra note 74, at 132; see also note 228 infra and accompanying text (Ohio legislative committee report cites Criminal Abortion).

153. H. STORER \& F.F. HEARD, supra note 95, at 97-103. Storer and Heard addressed the role of male physicians in a separate chapter entitled "Its Innocent Abettors." Id. at 104-35.

Storer and Heard impugned the competence of midwives and female physicians with the summary observation that

they still are and must be subject to the periodical infirmity of their sex; which for the time, 
female crime, encouraged by female practitioners ${ }^{154}$ and indulged in by unruly female patients. A standard complaint attacked pregnant women for refusing to comply with medical advice during "confinement":

They eat and drink, they walk and ride, they will practice no self restrainment, but will indulge every caprice, every passion, utterly regardless of the unseen and unloved embryo. ... [E]very obstetrician can bear testimony to the great difficulty of inducing our wayward patients to forego certain gratifications, to practice certain self-denials, and to adopt efficient means for the salvation of the child. ${ }^{155}$

In demanding public action to protect unborn life, the doctors were simultaneously attempting to control women who were their competitors and clientele. Yet these parochial professional concerns plainly converged with wider cultural preoccupations. The "wayward patients" whom the doctors sought to control were none other than rebellious wives. As one doctor observed, there was " "widespread determination on the part of many who are married to avoid the labor of caring for and rearing children." "156 Another physician warned of women's " increasing propensity to fight against the maternal instinct," "complaining that " '[s]ome wives are bold enough to declare that they do not want any children; and a few even dare to proclaim openly that they will forego propagation if possible." "157 As the antiabortion campaign perceived and portrayed her, the wife who chose to abort a pregnancy challenged the social structure of marriage itself. The profession thus invested the act of abortion with wider social implications, depicting it as an expression of women's resistance to marital and maternal obligation.

The campaign invested abortion with gendered significance by means both overt and oblique, many of which are not immediately apparent to a modern audience. When campaign rhetoric is examined in socio-political context, it becomes clear that the medical profession was engaged in a debate with the feminist movement of the era over the institution of marriage and

and in every case, however unattended by physical suffering, unfits them for any responsible effort of mind, and in many cases, body also. . . . We could hardly allow to a female physician convicted of criminal abortion the plea that the act was committed during the temporary insanity of her menstruation; and yet at such times a woman is undoubtedly more prone than men to commit any unusual or outrageous act.

Id. at 100 n.2. In the 1859 edition, Storer denied that his purpose was to suppress midwives and female physicians; in the 1868 edition, he retracted the denial, explaining that his personal experience with female physicians proved that they were unfit to practice. Id.; cf. J. MoHR, supra note 65, at 168-69 (Storer supports AMA efforts to exclude women from the profession).

154. The professional concerns underlying Storer's account of women's role in abortion were also expressed by Edwin Hale: 'Female Abortionists, assume the name of 'Midwives,' 'Nurses,' 'Fortune-tellers,' 'Madam - Female Physician,' et cetera, and under these apparently harmless avocations, ply their murderous trade." E. HALE, supra note 123, at 17; see also J. MoHR, supra note 65, at 161 (Detroit physicians characterizing the abortionist as an "old woman, of one sex or the other"). Similarly, the Reverend John Todd, a follower of Dr. Augustus Gardner, argued in his antiabortion tract that "seventy-five per cent. of all the abortions produced are caused and effected by females." JoHN TOdD, SERPENTS IN THE DOVES' NEST 4 (Boston, Lee \& Shepard 1867).

155. H. HoDGE, supra note 108, at 32-33; see also Pallen, supra note 68, at 202-03.

156. J. MoHr, supra note 65 , at 89 (quoting Dr. George E. Smith of Hillsdale, Michigan).

157. 3 A. Calmoun, supra note 126, at 242 (quoting Thomas S. Sozinskey, M.D., in Potter's American Monthly of 1881). 
motherhood that only peripherally concerned the question of abortion. Reconstructing this debate reveals the political reference and social resonance which antiabortion rhetoric had for its nineteenth century audiences. By identifying the practice of abortion with feminist criticism of prevailing gender roles, the campaign encouraged Americans to oppose birth control as a means of defending prevailing gender roles. The profession's antifeminist arguments imbued the practice of controlling birth with emancipatory significance, whether or not it had this meaning for women who sought abortions.

\section{The aborting wife: antiabortion as antifeminism.}

The doctors who led the criminalization campaign regularly complained that it was America's wives who most frequently sought abortions. ${ }^{158}$ While doctors sometimes attributed the prevalence of abortions to women's ignorance of the reproductive process ${ }^{159}$ or to aberrations in feminine judgment induced by pregnancy, ${ }^{160}$ they more frequently portrayed abortion as reflecting a growing self-indulgence among American women. ${ }^{161}$ Doctors scarcely acknowledged that wives had meaningful reasons for aborting a pregnancy; instead, they attributed the practice to simple egoism. Dr. Andrew Nebinger spoke for many when he observed that most women sought abortions because of "the inconvenience incident to pregnancy, fear of the pains and risks of labor; but mainly ... to avoid the labor and the expense of rearing children, and the interference with pleasurable pursuits, fashions, and frivolities." 162 Nebinger invited his audience to consider "the causes inducing the committal of the crime" and find "even a shadow of a sufficient reason" for an abortion. ${ }^{163}$ As the profession presented it, all of women's reasons for seeking an abortion were equally and unnaturally egoistic because all were derogations of maternal duty. Augustus Gardner made this quite explicit:

158. See generally C. DEGLER, supra note 74, at 229-33 (surveying medical literature); J. MoHR, supra note 65, at 86-90 (same).

159. See K. LUKER, supra note 65, at 21-22. But see id. at 23-26 (popular manuals on birthing reflect an understanding of gestational development as continuous, thereby suggesting that vomen understood the facts of physiological development, but differed with doctors over their moral import); Sauer, supra note 88, at 56 ("While the literature universally condemned abortion, all writers agreed that a large segment of the public did not regard abortion as such a heinous practice."); see also Pallen, supra note 68, at 201 ("when such individuals are informed of the nature of the transaction, there is an expression of real or pretended surprise, that any one should deem the act improper, much more guilty").

160. See Walter Channing, Effects of Criminal Abortion, 60 Boston MEd. \& SuRgical J. 134, 135 (1859) ("Women for whom this office of foeticide . . . is committed, are strong-minded, and the natural is strengthened by the recently-established uterine function. It becomes irritable, morbidly sensitive, ... and what is resolved upon is done."), quoted in C. SMrTH-RosenBERG, supra note 65, at 238; see also H.R. STORER, supra note 79 , at 74-75.

161. J. MOHR, supra note 65 , at 108 (citing doctors who attributed the incidence of abortion to the "growing self-indulgence among American women").

162. A. NeBINGER, supra note 140 , at 11 .

163. Id. See E. Hale, supra note 123, at 7-15 (reviewing and dismissing all rationales women might advance for aborting, finding most of them "shallow"). The complaint was commonplace and the rhetoric standard. Hugh Hodge attributed wives' practice of abortion to "the fear of labor, ... [the] indisposition to have the care, the expense, or the trouble of children, or some other motive equally trifling and degrading." H. HODGE, supra note 108, at 32-33. Montrose Pallen echoed him verbatim. Pallen, supra note 68 , at 201. 
"Is it not arrant laziness, sheer, craven, culpable cowardice, which is at the bottom of this base act? . . . . Have you the right to choose an indolent, selfish life, neglecting the work God has appointed you to perform?"164

The campaign did offer other explanations for women's efforts to avoid motherhood. Some doctors blamed antimaternalism on fashions of leisure and luxury accompanying industrialization; ${ }^{165}$ others insisted its roots were more importantly political than social, attributing the incidence of abortion to disturbances produced by woman's rights advocacy.

Statements hostile to the woman's rights movement appeared in many of the antiabortion tracts penned by America's doctors and their supporters. ${ }^{166}$ The campaign's leader, Horatio Storer, announced his antifeminist views as a statement of first principles: "I would not transplant [women] from their proper and God-given sphere, to the pulpit, the forum, or the cares of state, nor would I repeat the experiment, so patiently tried by myself, and at last so emphatically condemned- - of females attempting the practice of the medical profession."167 More frequently, however, the doctors attacked feminist advocacy on the grounds that it incited American women to practice abortion. ${ }^{168}$ Thus, Dr. Montrose Pallen attributed birth control practices to the corrosive influence of the woman's rights movement:

Woman's rights and woman's sphere are, as understood by the American public, quite different from that understood by us as Physicians, or as Anatomists, or Physiologists.

"Woman's rights" now are understood to be, that she should be a man, and that her physical organism, which is constituted by Nature to bear and rear offspring, should be left in abeyance, and that her ministrations in the

164. Gardner, supra note 126 , at 225 . A physician identifying himself only as D.H. counseled doctors to rebuke wives who approached them for an abortion in similar terms: "[A]re you not ignoring the demands of duty and pleading the most intense and unmitigated selfishness as a justification for destroying life? Is self-indulgence the only thing to be sought in this life?" D.H., supra note 134, at 200. Similarly, the AMA's 1871 Report on Criminal Abortion depicted abortion as a breach of marital duty, indulged in by the wife who "yields to the pleasures but shrinks from the pains and responsibilities of maternity." O'Donnell \& Atlee, supra note 121, at 241 (quoted in text accompanying note 128 supra).

165. See A. GARDNER, supra note 79, at 17-18, 180-81, 224-29. Industrialization did provide economic incentives for middle-class families to practice birth control. See text accompanying notes 86-88 supra. But cf. J. MoHR, supra note 65, at 107-08 ("The most common variant of the view that abortion was a manifestation of the women's rights movement hinged upon the word 'fashion." ").

166. See J. MOHR, supra note 65, at $104-09$ (discussing antifeminism of the doctors' campaign against abortion); see also G.J. BARKER-BENFIELD, supra note 149, at 84-85, 87-88, 193, 284-85 (on antifeminist attitudes of nineteenth century medical profession); J. HALLER \& R. HALLER, supra note 113, at 76-87, 123; S. STAGE, supra note 80, at 84-85; Graham John Barker-Benfield, The Spermatic Economy, in THE AMERICAN FAMILY IN SOCIAL-Historical PERSPECTIVE 385 (Michael Gordon ed., 2d ed. 1978).

The antifeminist motif of the medical profession's campaign against abortion was perpetuated by nonprofessional critics of the practice. John Todd, one of the most outspoken religious opponents of abortion, wrote both antiabortion and antifeminist tracts. Compare J. TODD, supra note 154, with JoHN TODD, Woman's Rights (Boston, Lee \& Shepard 1867).

167. H.R. STORER, supra note 123, at 89-90.

168. Cf. H. STORER \& F.F. HEARD, supra note 95, at 2 n.1 (discussing woman's rights tract "in which, however covertly, the idea is practically upheld, that, whatever her other rights, a woman is certainly entitled to decide whether or no she shall bear children"); Gibbons, supra note 88, at 10507, 111 (blaming feticide on antimaternalism and free love). 
formation of character as mother should be abandoned for the sterner rights of voting and law making.

The whole country is in an abnormal state, and the tendency to force women into men's places, creates new ideas of women's duties, and therefore ... the marriage state is frequently childless .... These influences act and react on public sentiment, until the public conscience becomes blunted, and duties necessary to woman's organization are shirked, neglected or criminally prevented. ${ }^{169}$

H.S. Pomeroy reasoned along similar lines, contending that "it is impossible to treat the sin against parenthood without touching upon what is called the Woman Question."170 He charged that the "opinions and theories" of "many ... connected with the Woman's Rights Movement, and at least, some of the advocates of higher education for women . . . indirectly at least, have aided and abetted the sin against maternity."171 As he explained:

There are lecturers "to ladies only" who profess to be actuated simply by good-will toward their unfortunate sisters, who yet call woman's highest and holiest privilege by the name of slavery, and a law to protect the family from the first step toward extinction, tyranny.

There are apostles of woman's rights who, in their well-meaning but misdirected efforts to arouse women to claim privileges now denied them, encourage their sisters to feel ashamed of the first and highest right which is theirs by the very idea of their nature.

There are advocates of education who seek to deter woman by false pride, from performing the one duty she is perfectly sure of being able to do better than a man! And there are those who teach that their married sisters may save time and vitality for high and noble pursuits by "electing" how few children shall be born to them .... ${ }^{172}$

Doctors considered abortion as a rebellious, incipiently political act, so that for Pallen and Pomeroy, women's conduct in " 'electing' how few children shall be born to them" suggested an interest in exercising the franchise itself. By linking abortion to feminist advocacy, the medical profession invested abortion with far-reaching social import. To grasp the rhetorical terms and practical concerns of the campaign's antifeminist polemic in their largest form, it is necessary to examine the feminist demands physicians opposed.

\section{Feminism and the concept of voluntary motherhood.}

The doctors leading the antiabortion campaign could not directly indict the feminist movement for advocating abortion because, in this era, no leader of the American feminist movement publicly endorsed abortion or contraceptives as a method of birth control. ${ }^{173}$ Nineteenth century feminists

169. Pallen, supra.note 68, at 205-06.

170. H.S. POMEROY, supra note 114, at vii.

171. Id. at 137-38.

172. Id. at $95-96$.

173. See L. GoRdon, supra note 65, at 97-111; Linda Gordon, Why Nineteenth-Century Feminists Did Not Support 'Birth Control' and Twentieth-Century Feminists Do: Feminism, Reproduction, 
did demand reproductive choice. But their demand for "voluntary motherhood" referred, not to abortion, but instead to a wife's right to refuse her husband's sexual advances. ${ }^{174}$

The feminist movement's refusal to endorse abortion may be explained on several grounds. ${ }^{175}$ Yet focusing on this issue obscures the extent to which feminists of the era tacitly condoned abortion. ${ }^{176}$ It also obscures the wide-ranging conflict over marriage and motherhood in which medical opponents of abortion and feminist proponents of voluntary motherhood were engaged. Nineteenth century feminist demands for voluntary motherhood prompted debate over fundamental issues of women's status often neglected in the debate over abortion rights today.

Feminist demands for voluntary motherhood flowed from the movement's larger critique of marriage. From its inception, the woman's rights movement attacked the common law of marital status, which endowed a husband with rights in his wife's "services" in exchange for his obligation of support. Feminists protested the doctrine of marital service because it vested a husband with rights in a wife's labor and sexuality, transforming wives into "unpaid housekeepers \& nurses, \& still worse, chattels personal to be used and abused at the will of a master."177 As woman's rights advocates insistently argued, a wife had a right to self-ownership in marriage, or, as they put it, a right in her own body, and so was entitled to control her labor, sexuality, and reproductive life; the movement thus demanded rights for women which both law and custom viewed as prerogatives of the husband. Lucy Stone reflected on the logic of the movement's demands in a letter to Antoinette Blackwell written in 1855:

It is clear to me, that . . . all our little skirmishing for better laws, and the right to vote, will yet be swallowed up in the real question, viz: Has woman a right to herself? It is very little to me to have the right to vote, to own property, \&c. if I may not keep my body, and its uses, in my absolute right. Not one wife in a thousand can do that now, and as long as she suffers this

and the Family, in Rethinking the Family: Some Feminist Questions 40, 43 (Barrie Thorne \& Marilyn Yalom eds., 1982).

174. See L. GoRDon, supra note 65 , at 108-11.

175. Linda Gordon suggests that feminists of the era saw birth control practices as a threat to women's welfare precisely because they severed the relation between sexuality and procreative activity. Making birth control accessible would impair women's ability to secure and hold a husband and thus deprive them of a relation indispensable to their financial security, while conferring sexual freedom upon women in a cultural milieu in which they were unable to exercise it. See id. at 109-11.

It would have been difficult for the feminist movement to endorse birth control practices for other reasons. Endorsing abortion and/or contraception would have further marginalized the feminist movement, which was already depicted as inimical to family life, and continually attempting to refute charges that it promoted "free love." Just as importantly, endorsing birth control practices would have been at odds with the maternalist ethic from which many feminists drew moral power. See id. at 96-100.

176. See note 184 infra and accompanying text. For feminist arguments justifying abortion, see note 185 infra and text accompanying notes 202-205 infra. For a feminist argument "deploring" abortion, but opposing criminal abortion legislation, see note 206 infra.

177. Sarah M. Grimke, Marriage, in The Female Experience 89, 96 (Gerda Lerner ed., 1977) (1855 essay quoted and discussed at note 188 infra). 
bondage, all other rights will not help her to her true position. ${ }^{178}$

The demand for voluntary motherhood thus grew out of feminist criticism of marriage as an institution of economic and sexual disempowerment for women. ${ }^{179}$ In the years after the Civil War, this critique of marriage consolidated in the demand for voluntary motherhood, a concept which feminists employed in constructive and critical ways. On the one hand, the concept of controlling motherhood played a key role in a new vision of wives' emancipation: The demand for voluntary motherhood was asserted at a time when movement activists were beginning to explore various schemes for collectivizing domestic labor and to sketch out a relationship which they called "two-career marriage."180 At the same time, the concept of voluntary motherhood enabled feminists to voice far-reaching criticisms of the existing structure of the marriage-many of which took the form of commentary on the practice of abortion.

Unlike the medical profession, proponents of voluntary motherhood blamed the practice of abortion on the social conditions in which women conceived and raised children. Most frequently, they attributed the incidence of abortion to marital rape, ${ }^{181}$ but they also attributed abortion to the onerous work of motherhood, some even tracing it to the expropriation of women's domestic labor in marriage. ${ }^{182}$ For example, Abigail Duniway, edi-

178. Letter from Lucy Stone to Antoinette Brown (Blackwell) (July 11, 1855), quoted in Elizabeth Cazden, Antoinette Brown Blackwell: A Biography 100 (1983).

179. In the post-war period, a voluntary motherhood argument, virtually condoning abortion under prevailing conditions of marriage, defined woman's emancipation as: "The ability to frame laws, making the husband and wife equal owners in the property accumulated by their united industry and economy, [and] making the mother the guardian of her own children, the owner of her own body in short, the controller of her own destiny." M. Brinkerhoff, Woman and Motherhood, Revolution, Sept. 2, 1869, at 138; see also Matilda E.J. Gage, Is Woman Her Own?, Revolution, Apr. 9, 1868, at 215, 215-16 (situating abortion in the context of women's legal disabilities in marriage). For an account of nineteenth century feminism examining the movement's demands for reproductive autonomy in light of its wider socio-political agenda, see Ellen Carol DuBois, Outgrowing the Compact of the Fathers: Equal Rights, Woman Suffrage, and the United States Constitution, 1820-1878, 74 J. AM. HisT. 836, 842-44 (1987).

180. See Dolores Hayden, The Grand Domestic Revolution: A History of FemNIST DESIGNS FOR AMERICAN HOMES, NEIGHBORHOODS, AND CTTIES 66-131 (1981) (feminist schemes for cooperative housekeeping); William LEACH, TRue Love AND PERFECT UNION: THE FEMINIST REFORM OF SEX AND SOCIETY 195-202 (1980) (feminist visions of two-career marriage); id. at 202-12 (cooperative housekeeping).

181. See notes $184 \& 185$ infra. Storer discusses the frequency and practice of marital rape in Is it I?, H.R. STORER, supra note 123, which he intended for a male readership. See note 195 infra.

182. During the period of the criminalization campaign, the woman's rights movement repeatedly objected to the expropriation of women's family labor in marriage. See Reva Siegel, Home As Work: Political Feminism and the Question of Domestic Labor, 1850-1880 (1991) (unpublished manuscript, on file with the Stanford Law Review).

From this critique emerged a counter-narrative of domesticity, in which motherhood appeared as an institution that denied women the fruits of their labor. Readers of suffrage newspapers supported this critique with personal testimonials of their own exploitation. See, e.g., $A$ Wife's Protest, WOMAN's J., Mar. 6, 1875, at 72 (analyzing the social work of reproduction performed by a man's mother, mother-in-law, his first and sometimes second wife, and concluding that "[i]t takes three, and sometimes four women to get a man through from cradle to the grave .... It is time we stated facts and called things by their right names, and handled this subject without kid gloves"); Subjection of Women, THE BALlor Box, Nov. 1876, at 2 (letter from farmer's wife who raised nine children and cared for several grandchildren, reporting that "[h]usband owns and controls everything," 
tor of the suffrage paper The New Northwest observed: "All work becomes oppressive that is not remunerative. To this idea, more than any other, may be traced the prejudice against bearing children which has become so ingrafted upon the minds of married women, that tens of thousands annually commit ante-natal murder."183 Given their view of the conditions of conception and maternity, many feminists publicly condemned, yet tacitly condoned, women who turned to abortion. ${ }^{184}$ Some even argued that wives compelled to submit to marital relations were justified in aborting, characterizing abortion as an act of self-defense under prevailing conditions of "forced motherhood."185

Thus, the feminist demand to "keep my body, and its uses, in my absolute right" was no abstract statement of allegiance to principles of autonomy. It was a far-ranging critique of the social relations of reproduction embodied in institution of marriage. ${ }^{186}$ As structured by law and custom,

and "advising every woman to not do another day's labor unless she can be owner of the value of it"); see also Letter from S.H. Graves to Isabella Beecher Hooker (Oct. 24, 1871), in THE LiMITS oF SisTerhood 204, 204 (Jeanne Boydston, Mary Kelley \& Anne Margolis eds., 1988) ("Of course, [my husband] is bitterly opposed to 'woman's rights' and loses no opportunity for the usual sneer. I have no money and but few clothes.... [E]verything is his and nothing mine. In short I am nothing but a housekeeper without wages, doing all the work of the family."). It is this sense of motherhood as not merely life-giving, but life-consuming work, that drives the voluntary motherhood polemic and the two-career marriage concept to which it was increasingly affiliated.

183. Liberty for Married Women, NEw NoRTHwEST, Aug. 15, 1873, at 2. Matilda Gage argued substantially the same point in a letter to Revolution, which discussed abortion in the context of women's common law disabilities, especially the expropriation of their family labor. Gage, supra note 179; see Brinkerhoff, supra note 179, at 139.

184. For a popular marriage manual of the era condemning abortion, but virtually condoning it in cases of "enforced childbearing," see E.B. DuFFEY, WHAT WOMEN SHOULD KNOW: A WoMAN's BOOK ABOUT WOMEN 124-25, 130-33 (photo. reprint 1974) (Philadelphia, J.M. Stoddart \& Co. 1873). See also C. DEGLER, supra note 74, at 204-05 (discussing Duffey's career). Similarly, Henry Wright's argument for voluntary motherhood condemned abortion, but presented the onerous burdens of compelled motherhood in such vivid terms that his case histories effectively excused the actions of women who sought to terminate a pregnancy. See H. WRIGHT, THE UNWELCOME ChILD; OR, THE CRIME OF AN UNDESIGNED AND UNDESIRED MATERNITY (Boston 1858).

Whether or not proponents of voluntary motherhood condoned abortion in circumstances of compelled marital relations, they consistently attributed the incidence of abortion to such relations. Thus, an editorial in Stanton and Anthony's Revolution observed:

I know men who call themselves Christians, who would insist that they are gentlemen, who never insult any woman - but their wives. They think it is impossible that they can outrage them; they never think that even in wedlock there may be the very vilest prostitution; and if Christian women are prostitutes to Christian husbands, what can we expect but the natural sequence-infanticide?

Marriage and Maternity, Revolution, July 8, 1869, at 4; see also Child Murder, Revolution, Mar. 12, 1868, at 146-47.

185. See Child Murder, Revolution, Apr. 9, 1868, at 217 (quoted in text accompanying note 205 infra); Woman and Motherhood, REvoluTION, Sept. 2, 1869, at 138 ("As law and custom give the husband the absolute control of the wife's person, she is forced to not only violate physical law, but to outrage the holiest instincts of her being to maintain even a semblance of that freedom which by nature belongs to every human soul.").

186. Feminist demands for "self-ownership" derived from, and yet exceeded, the traditions of classical liberal thought. The demand for self-ownership was employed to criticize the conditions of conception and maternity in marriage, the very "contract" excepted from liberal paradigms of selfdetermination. Thus, feminists appropriated a liberal discourse of self-ownership, inverted its 
feminists insisted, marriage was little better than "legal robbery," 187 or, worse yet, a species of "legalized prostitution"-a polemic frequently employed in their attack on the law "which makes obligatory the rendering of marital rights and compulsory maternity." 188

\section{Voluntary motherhood: the debate.}

The doctors quite self-consciously attacked the voluntary motherhood critique. In their view, it was shirking the duty to procreate that rendered marriage a relation of "legalized prostitution." "I am thoroughly convinced with Dr. Storer of Boston," observed Thaddeus Reamy, "that ... preventing

gendered perspectives, and then used the discourse to mount a critique of the marriage relation. See Siegel, supra note 182.

It is important to note that, despite the sexual concerns of the demand for self-ownership and its repeated articulation in rhetorics of the body, the claim focused on the social, not physical, relations of reproduction. Consider Elizabeth Cady Stanton's early articulation of the demand for voluntary motherhood:

Did [man] ever take in the idea that to the mother of the race, and to her alone, belonged the right to say when a new being should be brought into the world? Has he, in the gratification of his blind passions, ever paused to think whether it was with joy and gladness that she gave up ten or twenty years of the heyday of her existence to all the cares and sufferings of excessive maternity?

Letter from Elizabeth Cady Stanton to Gerrit Smith (Dec. 21, 1855), in 1 HisTORY OF WOMAN Suffrage 839, 840 (Elizabeth Cady Stanton, Susan B. Anthony \& Matilda Joslyn Gage eds., New York, Fowler \& Wells 1881).

187. See, e.g., Resolutions of the Fifth National Woman's Rights Convention, in HISTORY OF Woman SUFFrage, supra note 186, at 817-18; Proceedings of the Woman's Rights Convention, Held at the Broadway Tabernacle in the City of New York, on Tuesday and Wednesday, Sept. 6th and 7th, 1853, at 59 (1853) (remarks of Clara Nichols) ("Man takes from her her right in propertyher right over her own earnings, and offspring and services, and then, to compensate her for the robbery, enacts that she shall be held under no obligation to support her children.").

188. Address by Paulina Wright Davis to a convention of the National Woman Suffrage Association (1871), quoted in L. GoRDON, supra note 65, at 104. Feminists denounced marriage as a species of "legalized prostitution" in the decades before and after the Civil War. In the antebellum era, for example, Sarah Grimke employed the charge to advance a social and legal critique of the marital relation. See Grimke, supra note 177, at $94-96$ (1855 essay responding to New York Times editorial charging that the woman's rights movement leads to "Free Love"):

A revolting experience has forced upon her the conviction that she is a legal prostitute, a chattel personal, a tool that is used, a mere convenience. Man seems to feel that Marriage gives him the control of Woman's person just as the Law gives him the control of her property. ...

....

... [Wives] have too soon discovered that they were unpaid housekeepers \& nurses, \& still worse, chattels personal to be used \& abused at the will of a master. O! the agony of realizing that personal \& pecuniary independence are annihilated by that "Law which makes the husband and wife one \& that one is the husband."

Elizabeth Cady Stanton and Ernestine Rose also condemned marriage as "legalized prostitution" in their demands for divorce reform at the Tenth National Woman's Rights Convention in 1860. See HISTORY OF WOMAN SUFFRAGE, supra note 186 , at 719,731 . In the post-war period, the movement continued the refrain, adopting it as part of its demands for voluntary motherhood. See, e.g., Marriage and Maternity, supra note 184, at 4:

[T] each [woman] that submission to any man without love and desire is prostitution; and thunder in her ear, 'Who so defileth the body, defileth the temple of the Holy Ghost!' let maternity come to her from a desire to cherish love and train for high purposes an immortal soul, then you will have begun to eradicate this most monstrous crime.

See also L. GoRdon, supra note 65, at 112; C. SMITH-ROSENBERG, supra note 65, at 242; DuBois, supra note 179 , at 843 . 
conception, is but little else than legalized prostitution."189 This polemical inversion was quite intentional. Montrose Pallen launched his attack on the woman's rights movement with the observation that "[m]arriage now seems to be, not for the purposes intended by the Creator, but . . . a species of legalized prostitution, whereby men and women strive not to have children."190 William Goodell even described "legalized prostitution" as the cause of feminist discontent: "The sexual instinct has been given to man for the perpetuation of the species. . . . Dissociate one from the other, and ... wedlock lapses into licentiousness; the wife is degraded into a mistress; love and affection change into aversion and hate."191 Lacking reproductive fulfillment, the wife "takes distorted views of life and of the marriage relation, and harbors resentment against her husband as the author of all her ills." 192

The doctors' use of the "legalized prostitution" polemic creatively distorted the feminist claim. Woman's rights advocates insisted that marriage was no better than legalized prostitution if a wife's consent to marital sex was inferred from the marital contract itself, or if marital sex was treated as a reciprocal obligation flowing from the fact of marital support. ${ }^{193}$ By contrast, doctors argued that marriage was a relation of legalized prostitution so long as man's natural sexual urge were allowed expression in marriage without reproductive consequence. ${ }^{194}$ Thus, while feminists used the critique of marriage as "legalized prostitution" to argue that wives should control deci-

189. E.g., Thaddeus A. Reamy, Report on Obstetrics, 21 Transactions OHIO ST. MED. Soc'Y 55, 59 n.* (1866), quoted in Harper, supra note 74, at 133. For examples of Storer's uses of the polemic, see H. STORER \& F.F. HEARD, supra note 95, at 127; H.R. STORER, supra note 123, at 97 (quoting Dr. John Gray, commenting on Why Not?); H.R. STORER, supra note 79, at 83.

190. Pallen, supra note 68 , at 205 . For a minister's use of the legal prostitution motif, see J. TODD, supra note 154, at 23-24.

191. Goodell, supra note 118 , at 162 .

192. Id.

193. Victoria Woodhull was perhaps the most radical proponent of this view. Woodhull employed the claim of self-ownership to criticize concepts of consent used to legitimate the terms of marital status law: "Every human being belongs to himself or herself by a higher title than any which, by surrenders, or arrangements or promises, he or she can confer upon any other human being. Self-ownership is inalienable." Victoria Woodhull, The Greatest Social Drama of Modern Times, The Beecher-Tilton Scandal (1873), reprinted in WoOdHull \& Claflin's WeEKLY: THE LIVES AND WRITINGS OF NOTORIOUS VICTORIA WOODHULl AND HER SISTER TENNESSEE CLAFLIN 38, 43 (Arlene Kisner ed., 1972). In 1873 she offered this portrait of the marriage relation:

To what does modern marriage amount, if it be not to hold sexual slaves, who otherwise would be free? . . . Beside the evils of improper sexual relations resulting from legalized prostitution, there are the still more terrific conditions to which they are condemned, who languish in single cursedness.... Add to this class who are sexually starved, those who are compelled to undesired relations with the legal owners of their sexual organs, and a sum total of misery is formed which altogether beggars description.

Victoria Woodhull, The Elixir OF Life, or Why Do We Die? 8-9 (New York, Woodhull \& Clafin 1873). Many in the feminist movement distanced themselves from Woodhull's forthright endorsement of "free love" principles. But others, like Isabella Beecher Hooker, Elizabeth Cady Stanton, and Susan B. Anthony stood by her. Cf. Letter from Isabella Beecher Hooker to Susan B. Anthony (Mar. 11 and 14, 1871), in THE LIMTTS OF SisTERHOOD, supra note 182, at 205 (attempting

- to coordinate a stance in which woman's rights activists will refrain from publicly endorsing, or criticizing, Woodhull).

194. See Goodell, supra note 118, at 162 (quoted in text accompanying note 191 supra); see also text accompanying notes 116-120 supra (discussing medical concepts of "physiological sin"). 
sions respecting reproduction, physicians used the same metaphor to justify depriving women of control over decisions respecting reproduction. ${ }^{195}$ In feminist usage, the critique of marraige as "legalized prostitution" identified a range of social reasons why a wife would seek to avoid maternity; in medical usage, the critique of marriage as "legalized prostitution" condemned the very aspiration to avoid maternity as an expression of unnatural egoism or immoral license.

The antiabortion campaign attacked the voluntary motherhood claim in other ways. Some doctors openly denounced the concept of two-career marriage, ${ }^{196}$ while others challenged its root premises. When, for example, Augustus Gardner complained, "The moral sense of the community is at a fearful pass. Each individual claims to decide for herself whether or not to have children," 197 he condemned not merely the practice of contraception and abortion, but, as his audience well understood, the feminist claim that motherhood was a choice for women rather than a duty. From this perspective, it is clear that the profession's continual denigration of women's reasons for aborting, and its incessant portrayal of the aborting wife as an unnatural egoist or a creature of fashion, were redolent with antifeminist animus. ${ }^{198}$

The profession's antifeminist polemic can be traced even further. Many of the profession's physiological arguments against abortion and contraception quite clearly disparaged the emancipatory aspirations of the voluntary motherhood claim. In condemning birth control practices, for example, Storer invoked arguments from physiology to mock the very notion that women could make responsible choices in matters of reproduction:

If each woman were allowed to judge for herself in this matter, her decision upon the abstract question would be too sure to be warped by personal considerations, and those of the moment. Woman's mind is prone to depression, and, indeed, to temporary actual derangement, under the stimulus of

195. Horatio Storer did find feminist claims of marital rape sufficiently troubling that he warned husbands to restrain the assertion of their conjugal rights in marriage, lest it drive wives to abortion. See H.R. STORER, supra note 79, at 11-13, 94-95 (discussing marital rape as lavful, but inappropriate, conduct). Yet, in so doing, he hastened to reassure his male audience:

And here let me say, that $I$ intend taking no ultra ground; that $I$ am neither a fanatic nor professed philanthrope; and that in loosing, as I hope to do, some of voman's present chains, it is solely for professional purposes, to increase her health, prolong her life, extend the benefits she confers upon society-in a word, selfishly to enhance her value to ourselves.

Id. at 89.

196. Dr. H.S. Pomeroy, for example, complained:

[T] here has grown to be a feeling among many women ... that the duties of maternity are a sort of low-grade drudgery which properly may be left to those who lack the will and ability necessary to carry them into a higher sphere. ... Some of our noblest women ... feel in their hearts a tendency to grudge the time and vitality demanded by the nursery. H.S. POMEROY, supra note 114, at 138; see also text accompanying notes 170-172 supra. He devoted an entire chapter of The Ethics of Marriage to the argument that women's reproductive role was incommensurate with paid labor, and contended that, in all but instances of economic necessity, women were to be supported by men. H.S. POMEROY, supra note 114, at 125-51; see also note 168 . supra.

197. Gardner, supra note 126, at 224-25.

198. See e.g., J. MoHR, supra note 65, at 107-08. 
uterine excitation, and this alike at the time of puberty and the final cessation of the menses, at the monthly period and at conception, during pregnancy, at labor, and during lactation .... .

Is there then no alternative but for women, when married and prone to conception, to occasionally bear children? This, as we have seen, is the end for which they are physiologically constituted and for which they are destined by nature. ... [The prevention and termination of pregnancy] are alike disastrous to a woman's mental, moral, and physical well-being. ${ }^{199}$

Motherhood was not a matter of choice for women; it was their destiny. The anatomical imperative the doctors discerned in a woman's reproductive organs "physiologically" negated the possibility of voluntary motherhood as a natural, legitimate, or lawful practice. 200

Just as medical opponents of abortion attacked the social premises of the voluntary motherhood claim, the woman's rights movement was quite outspoken in challenging the social premises of the antiabortion campaign. Though woman's rights advocates of the era seemingly (at least, publicly) accepted the doctors' scientific arguments against abortion, ${ }^{201}$ few conceded that the science of physiology supplied an analytical framework adequate to assess the morality of abortion. Even when feminists characterized abortion as a moral evil, they insisted on framing the ethical question more expansively, with attention to the social conditions of motherhood. From this perspective, those with the greatest moral culpability for abortions were not women, but men; women did not lack reasons for aborting a pregnancy, but instead suffered from an abundance of compelling social reasons for the act. Thus, a reader of the suffrage journal Revolution responded to a physician's

199. H.R. STORER, supra note 79, at 74-76. Thus, physiological arguments were used to attack the concept of voluntary motherhood in two ways. In addition to arguing that women's capacity to bear children rendered them incapable of making responsible choices in matters concerning reproduction, Storer (and others) claimed that women would injure their health if they practiced abortion or contraception or otherwise willfully resisted assuming the role of motherhood. See note 126 supra and accompanying text.

During the antiabortion campaign, Storer wrote a full-length treatise arguing that most cases of insanity in women could be traced to their reproductive system. See HORATIO ROBINSON STORER, The Causation, Course, and TREATMENT OF Reflex INSANITY IN WoMen 30 (photo. reprint 1972) (Boston, Lee \& Shepard 1871) ("[I]n women mental disease is often, perhaps generally, dependent upon functional or organic disturbance of the reproductive system."). For other examples of the gynecologists' theory that the reproductive system caused peculiar mental ("nervous") disorders in women, see H. STORER \& F.F. HEARD, supra note 95, at $100 \mathrm{n.2}$ (applying argument to midwives and female physicians); Channing, supra note 160, at 134-35; Christian, supra note 125, at 146.

200. Montrose Pallen made this explicit when he observed: "Woman's rights and woman's sphere are, as understood by the American public, quite different from that understood by us as Physicians, or as Anatomists, or Physiologists." Pallen, supra note 68, at 205 (quoted in full at text accompanying note 169 supra).

201. For a feminist who accepted the doctors' argument that the facts of embryonic development governed the ethics of abortion, see Lectures of Dr. Anna Densmore, Revolution, Mar. 19, 1868, at 170 (arguing that this information would change women's conduct). Cf. Woman and Motherhood, supra note 185, at 138 (arguing that a woman seeking an abortion is "forced to not only violate physical law, but to outrage the holiest instincts of her being to maintain even a semblance of ... freedom"). In her marriage manual, Eliza Duffey insisted that scientific knowledge of the reproductive process would deter women from seeking abortions, see E.B. DuFFEY, supra note 184, at 124-27, although her ensuing analysis of women's motives for aborting a pregnancy implied otherwise, id. at 127-33. 
report that "four hundred children were annually murdered in Androscoggin county, [Maine]" by questioning whether "educating women to the knowledge that there was life in the embryo" would in any way ameliorate the situation. ${ }^{202}$ The reader was acquainted with the physician, as well as with a few of the women included in his statistics, and observed, "I do not think this knowledge would deter one out of ten, if it did one out of a hundred, with us, from the commission of this deed. They do it with the knowledge that it endangers their own lives, but the cry is 'Liberty or Death.' "203 As she saw it, the crux of the abortion question was not the embryo, but the "wretched homes where heart-broken women work day and night, for the most shameful pittance, to provide food for the little ones whom the brutal lusts of a drunken husband have forced upon them."204 She closed her letter with the observation that "[t]he Tribune laments over this "conspiracy against marriage,' but it is time to conspire against an institution which makes one human being the slave of another," and signed it, "Conspirator."205 The letter is unusual in openly defending the practice of abortion, but representative of the voluntary motherhood claim in pivoting questions concerning the morality of abortion away from the physical, to the social, relations of reproduction-and consequently, in shifting the focus of social criticism away from the conduct of women to that of men. ${ }^{206}$

A few feminists directly challenged the authority of medical science, specifically objecting to the profession's efforts to politicize the physiology of reproduction. When asked by a magazine what she meant by a woman owning her own body, Elizabeth Cady Stanton replied: "[W]omanhood is the primal fact, wifehood and motherhood its incidents. . . . Must the heyday of her existence be wholly devoted to the one animal function of bearing children? Shall there be no limit to this but woman's capacity to endure the fearful strain on her life?" "207 In defining woman's demand to control her own body as an aspiration for a social identity distinct from "the one animal function of bearing children," Stanton was quite plainly repudiating the doctors' physiological arguments. ${ }^{208}$ Similarly, when Matilda Joslyn Gage re-

202. Child Murder, supra note 185 , at 217.

203. Id.

204. Id.

205. Id.

206. For example, an editorial in Revolution which "deplore[d] the horrible crime of childmurder" nevertheless criticized the New York Medical Gazette for advocating the enactment of a criminal abortion statute, insisting that "such a law [would] only mow[] of the top of the noxious weed, while the root remains." As the editorial explained, "[w]e want prevention, not merely punishment. We must reach the root of the evil, and destroy it." Marriage and Maternity, supra note 184, at 4. The editorialist described the social conditions in which women conceived and raised children, and observed: "It is clear to my mind that this evil wholly arises from the false position which woman occupies in civilized society ...."Id. She judged women who sought abortions "awfully guilty," but considered their guilt slight by comparison to men's: "[T] hrice guilty is he who, for selfish gratification, heedless of her prayers, indifferent to her fate, drove her to the desperation which impelled her to the crime." Id.; see also E.B. DUFFEY, supra note 184, at 127-33 (emphasizing male culpability for abortions of single and married women); H. WRIGHT, supra note 184 (same).

207. L. GoRDON, supra note 65, at 104.

208. This deliberate inversion of medical logic seems to have been a motif of Stanton's lectures 
viewed The Law of Population ${ }^{209}$ in 1878, she offered this sharp assessment of the political functions of scientific discourse:

The law of motherhood should be entirely under woman's control, but in order to be that, woman must first of all be held as having a right to herself. When society, and especially the church, becomes permeated with the belief that woman was created for herself, and not for man, that she and not man should be the law of the family; ... . when each girl born into the world is taught from birth that she, and no other, has a right to her own body; when each boy from birth is taught self-control, self-restraint, and that man has no right to enforce maternity, then "science" will not be asked to step into the domain of justice and inherent right, to settle questions of this nature. ${ }^{210}$

Scientific construal of the human body was a form of sexual politics, transposing religious and legal norms into physiological imperatives in a way that obscured questions of "justice and inherent right." As Gage well grasped, just as the feminist demand for bodily self-ownership was an attack on the social relations of reproduction, so the doctors' scientific arguments about the human body were offered in their defense. ${ }^{211}$ Gage's emancipatory vision of a "society ... permeated with the belief that woman was created for herself, and not for man, that she and not man should be the law of the family ... that she, and no other has a right to her own body" was

in the post-war period. In 1871, a newspaper reported that she was advising wives to "learn and practice the true laws of generation," insisting that the "[w]oman must at all times be the sovereign of her own person." Dubois, supra note 179, at 856, (quoting For Women Only, DES MoINEs DAILY REG., July 29, 1871). She described these lectures in correspondence to a friend: "Whenever we stay in town two days I talk one afternoon to women alone. The new gospel of fewer children and a healthy, happy maternity is gladly received." Letter from Elizabeth Cady Stanton to Martha Coffin Wright, June 19, 1871, quoted in Dubois, supra note 179, at 857 . In invoking "the true laws of generation," the "new gospel of fewer children," and "a healthy, happy, maternity," Stanton elaborated the creed of voluntary motherhood in terms that both invoked and inverted the doctors' arguments from reproductive physiology.

Antoinette Brown Blackwell challenged the sexual logic of scientific discourse by similar means. See Antoinette Brown Blackwell, Sex and Work-No. 7, WoMAN's J., Apr. 25, 1874, at 129 (applying physiological advice intended for men to women, and countering physicians' claims that women's reproductive role disabled them for all but one activity in life with the observation that woman was endowed "with a special structure and functions admirably adapted to enable her, far beyond man, to bear any unusual tax upon her energies, whether of underwork or of overwork, in one or in all directions"); $c f$. ROSALIND ROSENBERG, BEYOND SEPARATE SPHERES: INTELLECTUAL ROOTS OF MODERN FEMINISM 12-27 (1982) (examining ways in which feminists of the era participated in and challenged prevailing physiological discourses about women).

209. Annie Besant, The law of Population: Its Consequences, and Its Bearing Upon Human Conduct and Morals (New York, Asa K. Butts 1878). Besant was an English woman of socialist-feminist persuasion who accepted Malthusian premises and argued that the elevation of the working class required limitation of childbirth. Nevertheless, she rejected the notion that deferral of marriage (as advocated by Malthus and Mills) was an appropriate method, as it would encourage resort to prostitution. Besant thus argued for marital contraception.

210. Our Book Tale, Nat'l Citizen \& Ballot Box, Nov. 1878, at 2 (paper edited by Matilda Joslyn Gage, who likely reviewed book).

211. The review rejected Besant's endorsement of contraception, see note 209 supra, as resting on the "pernicious doctrine ... as to the necessities of man's nature, 'necessities' which call for the sacrifice of woman," and instead announced its belief "in the right of woman to herself, and in her right to the control of all such questions," concluding that "Mrs. Besant has the misfortune to look at this population question from the man stand-point." Our Book Tale, supra note 210, at 62. For Gage's views on the question of abortion, see Gage, supra note 179. 
precisely the vision that doctors explaining the "laws of physiology" were determined to occlude.

Thus, the physicians' campaign aroused opposition to abortion by two distinct strategies. Doctors demonstrated the threat to life abortion posed by tracing the practical consequences of the act, as it threatened the unborn, the health of America's wives, and the political power of their social class. At the same time, doctors aroused opposition to abortion by portraying the practice symbolically, as a symptom of women's resistance to the status constraints of marriage and motherhood. At the simplest level, this was accomplished by attributing abortion to the effects of woman's rights advocacy. But it was more powerfully effectuated by the profession's habit of opposing abortion in rhetorical terms that engaged, shadowed, and mocked woman's rights advocacy. Because campaign rhetoric explicitly and implicitly associated abortion with feminist demands to reform the laws and customs of marriage and to expand women's participation in economic and political life, doctors invested abortion with explosive social significance. The campaign thus encouraged nineteenth century audiences to oppose abortion as an emancipatory act-one that threatened gender roles in matters concerning sexuality and motherhood, education and work, and affairs of suffrage and state.

\section{The AMA's Accomplishments: The Example of Ohio}

"Between 1860 and 1880," James Mohr observes, "the regular physicians' campaign against abortion in the United States produced the most important burst of anti-abortion legislation in the nation's history."212 At least forty antiabortion statutes were enacted, with thirteen jurisdictions formally outlawing abortion for the first time, and at least twenty-one states revising existing legislation. ${ }^{213}$ The majority of states that adopted antiabortion statutes prohibited abortion induced before quickening, although many conditioned more severe criminal penalties upon proof of quickening. ${ }^{214}$ The penalties imposed for abortion and attempted abortion varied considerably in severity; ${ }^{215}$ a number of states broke with common law tradition and penalized women for seeking or obtaining an abortion. ${ }^{216}$ Federal legislation enacted in 1873, popularly known as the Comstock Act, classified information concerning contraception and abortion as obscene, and prohibited its

212. J. MoHR, supra note 65, at 200; see also id. at 200-45 (recounting the achievements of the physicians' campaign, in legislation enacted, as well as in the alteration of reproductive practices generally).

213. Id. at 200.

214. M. GROSSBERG, supra note 120 , at $174-75,185$ (suggesting punishment increased with late term abortions because of greater maturity of fetus and increased health risk to the woman on whom abortion was performed); James S. Witherspoon, Reexamining Roe: Nineteenth-Century Abortion Statutes and the Fourteenth Amendment, 17 ST. MARY's L.J. 29, 34 nn.18-19 (1985) (citing state statutes as of 1868 that increased punishment for abortion based on proof of quickening).

215. Witherspoon, supra note 214 , at 53 n. 70 .

216. Id. at 59-61. 
circulation in the U.S. mails. ${ }^{217}$ Many states adopted statutes banning contraceptives and abortifacients, as well as the distribution of information about them, in the years before and after enactment of the federal statute. ${ }^{218}$ So-called therapeutic exceptions to the new abortion legislation, which allowed the procedure where necessary to preserve a woman's life, removed control of decisions about abortion from women to the medical profession. ${ }^{219}$ In this respect, the AMA realized its professional ambitions in the criminalization campaign. With the enactment of criminal abortion legislation, the profession began to consolidate its control over the provision of medical care generally and women's reproductive health care in particular. ${ }^{220}$

Post-war abortion reform in Ohio illustrates all the preoccupations of the national campaign, and provides abundant evidence of the medical profession's role in persuading state legislators to adopt the new legislation. Doctors were active in Ohio, as they were elsewhere, ${ }^{221}$ in pushing for reform of the state's criminal abortion statute. ${ }^{222}$ Two statutes were enacted in 1867 as a result of the physicians' advocacy. The first eliminated the quickening requirement of prior legislation, and made it "a high misdemeanor" punishable by one to seven years imprisonment to attempt, advise, or devise instruments for abortion which caused the death of a "vitalized embryo, or foetus, or mother."223 The second was a mini-Comstock law, adopted to "prevent

217. Comstock Act, ch. 258, 17 Stat. 598 (1873) (repealed 1909). On the history of the Comstock legislation, see C.T. DIENNES, supra note 120, at 20-42; M. GROSSBERG, supra note 120, at 176-77, 187-93; Paul, supra note 120; Harper, supra note 74, at 183-207.

218. See C.T. DIENNES, supra note 120, at 42-47; M. GROSSBERG, supra note 120, at 177-93; J. MoHR, supra note 65, at 200-25; Harper, supra note 74, at 179-83, 207-09.

219. See K. LUKER, supra note 65 , at 32-35 (explaining that by 1900 the vast majority of state statutes had a therapeutic exception conferring discretion upon doctors to determine what abortions were necessary to preserve a woman's life; the criminalization movement may thus be understood to have reallocated social responsibility for assessing the conditional rights of the pregnant woman and fetus, shifting that responsibility from women to the medical profession); Witherspoon, supra note 214 , at 45 n.49 (citing various state statutes).

220. See K. LuKER, supra note 65, at 32-45; J. MoHR, supra note 65 , at 160-64; id. at 238-39 (assessing achievements of the physicians in securing professional control of the field).

221. For the medical profession's role in lobbying other state legislatures, see, e.g., J. MoHR, supra note 65, at 205-06 (Illinois); id. at 210-11 (Vermont); id. at 211-15 (Maryland); id. at 215-19 (New York); id. at 219-21 (Michigan).

222. The Ohio state medical society delivered a memorial to the State Senate Judiciary Committee demanding tougher criminal abortion laws. A special committee created to consider the petition was duly lobbied by the physicians, and the report the committee produced (advocating the adoption of more stringent abortion laws) amply reflects the medical profession's advocacy. See id. at 206-07.

223. Act of Apr. 13, 1867, 1867 Ohio Laws 135-36, repealed by Amended Substitute House Bill No. 511, 1972 Ohio Laws 2032 (Vol. 134), quoted in Witherspoon, supra note 214, at 63. This act amended legislation enacted in 1834 which was in fact exceptionally severe for the year of its enactment: The 1834 act classified attempted abortion at any stage of pregnancy as a misdemeanor, unless necessary to save the life of the mother or advised by two physicians as necessary for that purpose. The crime was punishable by up to one year of imprisonment and/or a fine of up to $\$ 500$. Abortion after quickening was classified as a high misdemeanor, punishable by one to seven years imprisonment. OHIO GEN. STAT. \$§ 111, 112, at 252 (1841) (enacted Feb. 27, 1834), quoted in Quay, supra note 85, at 504; see also J. MoHR, supra note 65, at 39 . The post-bellum statute eliminated this quickening requirement. 
the publication, sale or gratuitous distribution of drugs, medicines and nostrums intended to prevent conception, or procure abortion."224 A published report of the state senate special committee that introduced the legislation illustrates the full impact of the physicians' campaign.

The report opened by denouncing the "alarming and increasing frequency" of abortion as it reduced "the number of children born alive of native American parentage" in the nation generally and in Ohio in particular. ${ }^{225}$ The committee attributed its understanding of abortion to the AMA, indicating that it had "drawn many of the facts presented in this report" from Horatio Storer's essay Why Not?, ${ }^{226}$ published one year earlier. ${ }^{227}$ The report then proceeded to reject the common law doctrine of quickening on physiological grounds. It sought to have it "proclaimed to the world, and ... impressed upon the conscience of every woman in the land [that abortion is] 'murder.' "228 To substantiate this judgment, the report contended that the "independent existence" of the fertilized ovum was demonstrable, offering as proof the embryo-as-suckling-infant analogy Storer elaborated in Why Not?.229 It then shifted focus, demanding more stringent criminal abortion laws for reasons related to women's conduct. The report characterized abortion as a source of grave physical and moral danger to women, because abortion was a "violation of nature's laws" and "[a]ny interference with nature's law results in evils innumerable."230 It deplored the ignorance which led "our otherwise amiable sisters to the commission of this crime," and held women who resisted motherhood in the utmost contempt, condemning those who yielded to "[t]he demands of society and fashionable life" and suc-

224. Act of Apr. 16, 1867, 1867 Ohio Laws 202-03, repealed by Amended Substitute House Bill No. 511, 1972 Ohio Laws 2032 (Vol. 134), quoted in J. MoHR, supra note 65, at 209.

225. 1867 OHio SeNATE J. APP. 233, 233, 235 (twice noting that abortion was most prevalent among the privileged classes).

226. H.R. STORER, supra note 79.

227. OHIO SENATE J. APP., supra note 225, at 233, 235 (citing essay under earlier title).

228. Id. at 234 (quoting H.R. Storer, ON Criminal Abortion IN AMERICA (Philadelphia, J.B. Lippincott \& Co. 1860)).

229.

When the impregnated ovum leaves the ovary and enters the womb, it becomes attached to that organ by a net-work of vessels, through which it receives its nourishment from the mother, just as after birth it is nourished from its mother's breast, and it has an independent existence as much in one case as the other.

Id. The passage from the committee report is borrowed from the argument of Storer's Why Not?. Cf. text accompanying notes 100-104 supra (discussing Storer's use of suckling infant and kangaroo analogies to establish the independent existence of the unborn).

230. Ohio SenATE J. APP., supra note 225, at 234. The committee cited many health risks, including sterility and death, that might result from interruption of the normal progress of gestation, id., offering an abbreviated version of arguments Storer advanced in Why Not?. See H.R. STORER, supra note 79 , at $36-38$.

As Storer encouraged, the committee viewed the physical harms that might result from an abortion as evidence that abortion violated natural law. $C f$. note 126 supra and accompanying text. Like Storer, the committee argued that abortion placed a woman at physical risk because she interfered with the purposes nature intended for her body. OHro SENATE J. APP., supra note 225, at 234. Thus, the public health reasons for regulating abortion were also moral arguments for regulating abortion, rooted deep in the gender code. $C f$. note 123 supra and accompanying text (pregnancy "necessary to the physical and moral health of women"). 
cumbed to "the desire of freedom from care and home duties and responsibilities."231 The report concluded with a stern warning to the married women of Ohio. Echoing Storer's tract, Why Not?, the report charged that wives who "avoid[ed] the duties and responsibilities of married life" were "living in a state of legalized prostitution," thereby endangering the manifest destiny of the race. ${ }^{232}$

The committee, however, was unable to secure a statute punishing abortion as murder. Instead, the legislature classified abortion at any stage of gestation as a "high misdemeanor."233 Nor did the committee persuade the legislature to abolish women's common law immunity for soliciting or obtaining an abortion, although the state senate considered adopting an amendment that would have criminalized only a married woman's participation in her own abortion. ${ }^{234}$ The legislature's readiness to consider such an unprecedented measure suggests that it was in fact influenced by the committee's argument that imposing restrictions on abortion was necessary to enforce wives' marital obligations. Indeed, the legislature's decision during that same session to adopt a statute criminalizing contraceptives and abortifacients demonstrates that the physicians were generally successful in advancing their pronatalist agenda. Ohio's criminal abortion statute was enacted out of a confluence of concerns, reflecting an interest in enforcing women's adherence to marital roles, in preserving the hegemony of those of "native American parentage," and in protecting unborn life. These concerns were mutually reinforcing motivations at the state and national level.

As the legislative record in Ohio suggests, doctors presented the protection of unborn life as a means to various social goals as much as an end in its

231. Ohio Senate J. APP., supra note 225, at 235.

232. See id:

Do [our otherwise amiable sisters] realize that in avoiding the duties and responsibilities of married life, they are, in effect, living in a state of legalized prostitution? Shall we permit our broad and fertile prairies to be settled only by the children of aliens? If not, we must, by proper legislation, and by the diffusion of correct public sentiment, endeavor to suppress a crime which has become so prevalent.

Cf. H.R. STORER, supra note 79 , at 83,85 . The passage in question combines a version of the legal prostitution polemic, see text accompanying notes 189-191 supra, with a version of the manifest destiny argument Storer advanced in Why Not?, see text accompanying note 144 supra.

233. See note 223 supra and accompanying text. For a discussion of the Ohio legislature's resistance to the physicians' arguments in favor of criminalization, see J. MoHR, supra note 65 , at 209-10. The physicians well understood that public sentiment opposed such stringent penalties on abortion. See Witherspoon, supra note 214, at 52 (noting that in 1872, the New York Medico-Legal Society considered a proposal to make abortion a capital felony, and rejected it on the theory that it would reduce chances of obtaining a jury conviction); see also E. HALE, supra note 123, at 33 (distinguishing between the theory that punishment for abortion should be constant throughout pregnancy and the practical political reality that "until the popular sentiment is educated up to the proper point, it may be impossible to procure a law so stringent and severe"; advocating increased punishment for late-term abortions); note 214 supra and accompanying text (states adopt criminal penalties that distinguish between abortion prior to and after quickening).

234. The proposed amendment failed by one vote. See J. MoHr, supra note 65 , at 208-09. The concept of singling out married women for more stringent punishment surely reflected the doctors' advocacy. Storer explicitly suggested that while all women seeking abortions should be subject to criminal sanctions, married women ought be punished more harshly. See H. STORER \& F.F. HEARD, supra note 95, at 145. 
own right. Protecting unborn life simultaneously functioned as a method of enforcing marital roles and protecting the political prerogatives of the physicians' social class. The argument that contraception and abortion endangered women's health echoed and reinforced these sentiments, rationalizing the criminalization of birth control in paternalist terms that defined women's physiological welfare as a condition of perpetual reproductive activity. ${ }^{235}$

Thus, the argument for protecting unborn life that stood at the heart of the campaign cannot be understood apart from the social concerns that motivated the campaign. Men interested in establishing their professional authority over women's role in reproduction encouraged other men to assert their political authority over women's role in reproduction by criminalizing the means of controlling birth, each acting to preserve life in the social order as they knew it. There is no reason to doubt that advocates of criminalization sought to protect unborn life; but it is equally clear that they perceived the unborn as threatened by rebellious middle-class women and teeming immigrant populations, and it is in this context that their judgments about the morality of abortion and contraception must be understood. Those who valued the unborn as worthy of protection valued women as worthy of respect only insofar as they adhered to their social role in the reproduction of life. ${ }^{236}$ Concerns of gender, ethnicity, and class were not peripheral to this ethic, but an integral part of it. The interest in protecting unborn life was an interest in preventing (certain) women from practicing birth control.237

235. There is no doubt that abortion posed health risks to women, but it is not clear that, absent criminal sanctions, the risks of abortion were any greater than the risks of childbirth-or even that the medical profession believed they were. See note 125 supra.

Cyril Means has argued that a concern to protect women's health motivated enactment of the criminal abortion laws in New York. See Means, supra note 96. The argument that abortion posed health risks to women appears in Ohio's committee report, supra note 225; see note 230 supra and accompanying text, and the Supreme Court gave considerable weight to this explanation for the enactment of criminal abortion laws in Roe. See Roe v. Wade, 410 U.S. 113, 149-51 (1973). In retrospect, it is impossible to assess the force or sense of this concern. It may have reflected a response to sensational newspaper coverage of women maimed or killed by abortionists, or deference to medical authority in the matter. But these arguments may well have been compelling as they played upon the larger sentiments the doctors' campaign so assiduously cultivated: Abortion was dangerous to women's health because it interrupted their "natural" physiological function and purpose in life. See notes $123,126 \& 230$ supra and accompanying text.

236. This ethic is plainly expressed in Ohio's abortion reform record. Similar sentiments are reflected in the New York record. In 1867, the Medical Society of the State of New York conveyed to the state assembly its view that abortion was "murder," and thereafter resolved "[t]hat this society will hail with gratitude and pleasure, the adoption of any measures or influences that will, in part or entirely, arrest this flagrant corruption of morality among women, who ought to be and unquestionably are the conservators of morals and virtue." 1867 N.Y. AssembLY J. 443, 443-44. The moral standard invoked was part of a gender code that defined women as mothers, the same code that led Ohio legislators to condemn women for "avoiding the duties and responsibilities of married life," and thus "living in a state of legalized prostitution." See text accompanying note 232 supra. Within a year, New York adopted a "mini-Comstock" statute similar to Ohio's, which not only strengthened sanctions against abortion, but for the first time outlawed contraception. See note 120 supra and accompanying text (situating New York's statute in context of campaign arguments against nonprocreative marital sexuality).

237. Arguments for criminalizing abortion and contraception reasoned about the unborn in a manner distinctive to the birth control context. Though doctors sometimes characterized abortion as murder, they did not expect legislators to punish abortion as murder and even recognized that the 


\section{E. A Transformation in the Law of Gender Status}

The campaign to criminalize birth control had significant effects on law. Physicians offered the American public a new way of understanding the social relations of reproduction, and with it, a new method of regulating them, one detached from traditional doctrines of marriage and family law. ${ }^{238}$ Laws against abortion and contraception fused concerns about reproduction of the social order with concerns about the physical process of reproduction, thus resembling antimiscegenation laws ${ }^{239}$ and other eugenics legislation ${ }^{240}$

penalties for abortion would vary with the stage of gestation. See note 233 supra; see also note 214 supra and accompanying text (discussing structure of criminal penalties in post-war abortion legislation).

Other examples illustrate the context-specific manner in which the American legal system reasoned about unborn life. When New York criminalized abortion from the point of conception, the state preserved unaltered a law allowing the execution of a pregnant felon unless she were quick with child. See Means, supra note 96, at 441-42. Similarly, in 1884, after Massachusetts adopted its reform statutes, State Supreme Court Justice Oliver Wendell Holmes ruled that a quickened fetus surviving a tortiously induced miscarriage for ten to fifteen minutes was not a "person" within the meaning of the state wrongful death statute. Holmes reasoned that the fetus "was a part of the mother at the time of the injury." Dietrich v. Northampton, 138 Mass. 14, 17 (1884). Until 1946, all American jurisdictions followed Dietrich's ruling that the common law did not recognize a cause of action in tort for prenatal injuries to a fetus. See Stallman v. Youngquist, 125 Ill. 2d 267, 271, 531 N.E.2d 355, 357 (1988); A.A. White, The Right of Recovery for Prenatal Injuries, 12 LA. L. REv. $383,394 \&$ n.50 (1952) ("A second reason given by most courts for denying recovery ... is that the child is a part of the mother until birth and therefore is not a person in being.") (footnote omitted). The value attached to unborn life in the criminalization campaign was thus context-specific: It pertained only to questions of birth control. For a contemporary illustration of the context-bound ways in which the law values unborn life, see William Saletan, Reductio ad absurdum in Missouri: If Fetuses Are People, New RePublic, Sept. 18 \& 25, 1989, at 18.

238. Unlike marital status laws of the sort cited in Frontiero v. Richardson, 411 U.S. 677, 684 (1973) (plurality opinion), which have ancient roots in Anglo-American common law, laws prohibiting the practice of abortion and contraception were adopted only in the nineteenth century. $C f . M$. GROSSBERG, supra note 120 , at 175 .

239. The term "miscegenation" was coined in 1864 by a New York newspaper editor, amid growing fears among Northern and Southern whites that emancipation of the slaves and enactment of federal civil rights legislation prohibiting discrimination in contracting would break down social and legal barriers to interracial marriage and cause an "amalgamation" of the races. See M. GRossBERG, supra note 120, at 136; Eva Saks, Representing Miscegenation Law, 8 RARITAN 39, $42-44$ (1989).

In the latter half of the nineteenth century arguments against interracial marriages began to emphasize issues of heredity, focusing on purity of lineage, or "blood." Saks, supra, at 40 . Increasingly, concerns about social reproduction of the racial order found expression in concerns about the physical act of reproduction in marriage. Eva Saks describes this shift: "theories of heredity begin to appear in miscegenation jurisprudence in Reconstruction, underwriting the modern institutionalization of blood and race. Social Darwinism, employing biology's survival mechanism to explain and justify social conditions, offered a philosophy of human hierarchy compatible with the general biologization that supported miscegenation laws." Id. at 45; see also THOMAS F. GOSSETT, RACE: THE HISTORY OF AN IDEA IN AMERICA 151 (1963) (citing Herbert Spencer, who urged that intermarriage should be " 'positively forbidden. It is not at root a question of social philosophy. It is at root a question of biology." "). On the rise of physiological modes of reasoning about race in the nineteenth century, see MichaEl BANTON, RACIAL THEORIES at xi-xii, 28-76 (1987) (explaining that notions of race as physiological type displace ethnographic models of racial difference). See also Michael Banton \& Jonathan HaRwood, The Race CONCEPT 26-27 (1975) (in 1800 George Cuvier makes first case for classifying races in permanent physiological types, and for the physiological causes of cultural variation); Peter J. Bowler, Evolution: The History of AN AMERICAN IDEA 98-99 (1984) (Spencer uses biological model of evolution to explain social position of the races). On the passage of antimiscegenation statutes in the Reconstruction era, see M. GrosSBERG, supra note 120 , at $136-40$. 
adopted in the postbellum period. Just as antimiscegenation laws of the era played an important role in maintaining a particular regime of racial status, laws that criminalized birth control helped maintain a particular regime of gender status. Considered in retrospect, the criminalization campaign can be understood as having both practical and jurisprudential effects on law, shaping both the means of regulating gender status and mode of its justification.

The significance of this change becomes apparent if one considers developments in marital status law during the era of the criminalization campaign. During the very period in which states were enacting the abortion legislation doctors sought, they were simultaneously reforming the common law of marital status in response to feminist demands. These reform statutes granted wives property rights in their own earnings, and conferred upon them the formal capacity to contract, to hold property in their own right, and to file suit. ${ }^{241}$ Criminalization of birth control thus proceeded during an era in which states were moderating, and in some cases abolishing, important elements of an ancient body of gender status law.

State legislatures apparently discerned no contradiction in criminalizing abortion while extending aspects of civil equality to wives; the two types of legislative reform flowed from distinct conceptual premises. ${ }^{242}$ The country was increasingly willing to concede that a married woman was a legal person, autonomous and distinct from her husband, but this concession of civil

240. Post-war developments in miscegenation law were part of a broader campaign to regulate marriage in order to control the production of offspring. In this period, various reformers persuaded state legislatures to regulate eligibility for marriage in such a way as to preclude "unfit" unions. As in the campaign against miscegenation, advocates for increased state supervision of those fit to marry often employed arguments from science or "physiology." M. GROSSBERG, supra note 120, at 14052. Like antiabortion statutes, eugenics restrictions on marriage channeled concerns about reproducing the social order into the physical act of reproduction itself. See C. ROSENBERG, supra note 67, at 33-34 (although scientific understanding of heredity "remained generally stable throughout the nineteenth century, hereditarian modes of explanation were utilized quite differently in the latter half of the nineteenth century," which witnessed an "increasingly aggressive employment of hereditarian arguments in the analysis of human behavior, especially antisocial behavior"); see also id. at 25-53 (hereditarian modes of explanation of the era); id. at 89-97 (eugenic thought); P. Bowler, supra note 239, at 274-78 (eugenic thought).

241. For a summary of reform as of 1861 , see Elizabeth Bowles Warbasse, The ChangING LEGAL RIGHTS OF MARRIED WOMEN 1800-1861, at 275-91 (1987). For an overview of reform statutes adopted in the 1860s and 1870s, see Richard H. Chused, Married Women's Property Law: 1800-1850, 71 GEo. L.J. 1359, 1424 n.361 (1983); Amy Dru Stanley, Conjugal Bonds and Wrage Labor: Rights of Contract in the Age of Emancipation, 75 J. AM. HIST. 471 (1988). See also NoRMA Basch, In the Eyes of The LAw: Women, Marriage, and Property in Nineteenth-CenTURY NEW YORK (1982).

242. The common law treated abortion in terms entirely distinct from questions of marriage. While the common law required a wife to obtain her husband's consent to engage in many transactions, it did not require wives to obtain spousal consent for an abortion. See Means, supra note 96, at 428-34. When state legislatures abolished the common law quickening distinction in criminal abortion laws, none imposed a requirement of spousal consent. See Quay, supra note 85, at app. (reprinting text of abortion and contraception statutes adopted during past century for all states). Medical proponents of criminalization did advocate imposing higher penalties on a married woman procuring an abortion, see, e.g., note 234 supra and accompanying text, but none seemed interested in requiring a husband's consent. Instead, the profession sought, and successfully secured, authority to appropriate that prerogative to itself. See notes 132 and 219 supra and accompanying text. 
personhood evidently had little to do with the special interest the public had in her conduct as a mother. In an incremental fashion, concepts of marital status had begun to change. State legislatures were now willing to recognize married women as legal persons, and to grant them rights in their earnings performed for third parties. But no state would grant a wife rights in her family labor. ${ }^{243}$ Those engaged in reforming the common law of marital status increasingly defined a wife's role with reference to her obligation to perform labor for the family, while those seeking to reform the common law of abortion defined a wife's role with reference to her obligation to bear children. ${ }^{244}$ These developments were mutually reinforcing, a product of the gender role conventions associated with the "separate spheres" tradition. With this reconceptualization of marital status norms, a wife was gradually transformed from a juridical appendage of her husband into one who performed the physical and social work of reproducing family life.

Thus, the campaign to criminalize abortion offered a new way of regulating wives' obligations that was distinct from, but in important respects consistent with, the traditional body of marital status law being reformed in the post Civil War period. In addition, it provided a new way of reasoning about wives' obligations. For centuries the Anglo-American common law had defined women's obligations through marriage, denominating the husband as his wife's "head and representative in the social state."245 By contrast, the criminalization campaign defined women's obligations physiologically, deriving women's duties from facts about the female body. In this way, the campaign made it reasonable to reason about women's roles as a status conferred by nature rather than by the social state.

Two renowned constitutional cases of the era supply evidence of this shift in gender status norms. In 1873, when the Supreme Court held in Bradwell v. Illinois ${ }^{246}$ that a woman's right to practice law was not a privilege and immunity of citizenship protected by the Fourteenth Amendment, Justice Bradley's concurrence invoked "nature" to justify the occupational exclusion, yet relied primarily upon women's social and legal status as wives to explain the proper boundaries of women's roles. ${ }^{247}$ By contrast, several

243. NANCy CotT, The Grounding OF MOdern Feminism 186-87 (1987); Reva Siegel, Of Status and Contract, Marriage and Market: Judicial Construction of the Earnings Statutes (1987) (unpublished manuscript, on file with the Stanford Law Review); see Arnold v. Rifner, 16 Ind. App. $442,443,45$ N.E. 618, 619 (1896) ("The [earnings] statute does not relieve the wife from the performance of any of the duties owing to her husband or family, but it simply vests in her the ownership of the earnings resulting from her services to others."); see also Lee v. Savannah Guano Co., 99 Ga. 572, 27 S.E. 159 (1896); Riley v. Mitchell, 36 Minn. 3, 29 N.W. 588 (1886); Coleman v. Burr, 93 N.Y. 17 (1883).

244. In this sense, the two reform movements were compatible, defining a wife's productive and reproductive labor in the family sphere as a matter of legal obligation.

245. Bradwell v. Illinois, 83 U.S. (16 Wall.) 130, 141 (1873) (Bradley, J., concurring); see note 247 infra.

246. 83 U.S. (16 Wall.) 130.

247. To demonstrate that "the civil law, as well as nature herself, has always recognized a wide difference in the respective spheres and destinies of man and woman," Justice Bradley invoked common law doctrines of marital status. Id. at 141 (Bradley, J., concurring). He emphasized that it was a maxim of that system of jurisprudence that a woman had no legal existence separate from 
decades later, when the Court decided in Muller v. Oregon ${ }^{248}$ that a state was free to enact protective legislation restricting women's employment as it could not men's, the Court justified its decision by reasoning from women's "physical structure," rather than the legal or social structure of the marriage relation. Muller's reasoning in fact illustrates this movement of gender status norms from the locus of marriage to the female body.

The Court began its analysis in Muller with the observation that:

The current runs steadily and strongly in the direction of the emancipation of the wife, and the policy, as disclosed by all recent legislation upon the subject in [Oregon], is to place her upon separate footing as if she were a feme sole, not only with respect to her separate property, but as it affects her right to make binding contracts. ${ }^{249}$

Yet, despite the contractual capacities recently conferred on married women by state statutes, and despite the constitutional liberty of contract recognized three years earlier in Lochner v. New York, ${ }^{250}$ the Court concluded that a state might nonetheless regulate women's employment:

Though limitations upon personal and contractual rights may be removed by legislation, there is that in her disposition and habits of life which will operate against a full assertion of those rights .... [H]er physical structure and a proper discharge of her maternal functions-having in view not merely her own health, but the well-being of the race-justify legislation to protect her from the greed as well as the passion of man. The limitations which the statute places upon her contractual powers, upon her right to agree with her employer as to the time she shall labor, are not imposed solely for her benefit, but also largely for the benefit of all. Many words cannot make this plainer. The two sexes differ in structure of body, in the functions to be performed by each .... This difference justifies a difference in legislation and upholds that which is designed to compensate for some of the burdens which rest upon her. ${ }^{251}$

The Court's decision in Muller, which relied on social science and medical evidence, ${ }^{252}$ was contemporaneously celebrated as an expression of social

her husband, who was regarded as her head and representative in the social state; and notwithstanding some recent modifications of this civil status, many of [its] special rules ... still exist in full force in most States.

Id. He stressed that a wife's inability to contract without her husband's consent "was one circumstance which the Supreme Court of Illinois deemed important in rendering a married woman incompetent fully to perform the duties of an attorney." Id.

In Justice Bradley's view, the fact that "many women are unmarried and not affected by [the common law]" was a mere "exception[] to the general rule," which dictated that "[t]he paramount destiny and mission of woman are to fulfill the noble and benign offices of wife and mother." Id. Justice Bradley did refer to "nature" as a basis for gender differentiation, but he primarily drew upon legal and social concepts of marriage to explain women's roles.

248. 208 U.S. 412 (1908).

249. Id. at 418 (quoting First Nat'l Bank v. Leonard, 36 Or. $390,396,59$ P. 873, 875 (1900)).

250. 198 U.S. 45 (1905).

251. Muller, 208 U.S. at $422-23$.

252. See id. at $419 \&$ n.1 (reciting public health evidence suggesting reduction of women's working hours was necessary in view of "(a) the physical organization of woman, (b) her maternal functions, (c) the rearing and education of the children, (d) maintenance of the home" as concerns "so important and so far reaching that the need for such reduction need hardly be discussed"); see 
realism in constitutional jurisprudence. ${ }^{253}$ But it was "realism" of a new sort. At least five times in Muller, the Court reiterated that its decision qualifying women's due process liberties reflected "woman's physical structure, and the functions she performs in consequence thereof"254-reasoning about women's bodies as no constitutional or common law opinion of the early nineteenth century ever did.

In Muller, the Court employed claims about women's bodies to reach a result which some decades earlier it might have justified by invoking the common law of marital status, as Justice Bradley did in Bradwell $v$. Illinois. ${ }^{255}$ The opinion's physiological reasoning and its repeated pronatalist themes ${ }^{256}$ are a product of the campaign to criminalize abortion as well as the interest in eugenics that grew in its wake. ${ }^{257}$ The campaign to criminalize abortion did not supplant marital status law, nor did it eliminate the use of marriage concepts in explaining women's social status. Instead it gave them more "modern," scientific sense. As the Muller opinion illustrates, the campaign enabled the Court to repudiate traditional norms of gender status and still find reasons for enforcing women's roles-reasons now rooted in immutable facts of nature rather than transitory and contestable social norms.

The criminalization campaign thus played a pivotal role in modernizing norms of gender status, affecting the manner in which the legal system both enforced and justified them. Precisely as the campaign modernized norms of gender status, it rendered them natural, reasonable, hence invisible. In the wake of the campaign, and we remain today in its legacy, facts about the female body possess normative force, justifying regulation of the female citizen. In the eyes of the law, women are corporeally embodied in circumstances where men are not, their bodies supplying reasons for the distinctive constraints imposed upon them.

\section{Fetal-Protective Regulation in Historical Perspective}

Were woman intended as a mere plaything, or for the gratification of her own or her husband's desires, there would have been need for her of neither uterus nor ovaries, nor would the prevention of their being used for their clearly legitimate purpose have been attended by such tremendous penalties

also id. at 421 (citing "abundant testimony of the medical fraternity" respecting women's physiology).

253. See, eg., Felix Frankfurter, Hours of Labor and Realism in Constitutional Law, 29 HARV. L. REV. 353, 364-65 (1916).

254. Muller, 208 U.S. at $420,421,422-23$.

255. 83 U.S. (16 Wall.) 130 (1873); see note 247 supra and accompanying text.

256. Muller, 208 U.S. at 421 ("[A]s healthy mothers are essential to vigorous offspring, the physical well-being of woman becomes an object of public interest and care in order to preserve the strength and vigor of the race."); $i d$. at 422 (twice invoking the "well-being of the race" as a justification for regulating women's employment).

257. See R. Hofstadter, supra note 67; Donald Pickens, Eugenics and the ProgresSIVES 32-46 (1968); see also 3 A. CALHOUN, supra note 126, at 225-54 (contemporary observers on "Race Sterility and Race Suicide"). 
as is in reality the case. ${ }^{258}$

- Horatio Storer (1866)

Our task, of course, is to resolve the issue by constitutional measurement, free of emotion and of predilection. We seek earnestly to do this, and, because we do, we have inquired into, and in this opinion place some emphasis upon, medical and medical-legal history and what that history reveals about man's attitudes toward the abortion procedure over the centuries. ${ }^{259}$

-Roe v. Wade (1973)

For some readers, the history of the nineteenth century campaign may be rich with present import, while others may find the connections between past and present more difficult to discern. It is therefore crucial to consider how the history of the campaign bears on contemporary modes of reasoning about reproductive regulation before attempting to situate the question of abortion in a constitutional framework.

If one examines contemporary arguments for protecting unborn life, it is readily apparent that physiological justifications for regulating women's conduct persist. By contrast, claims about women's roles openly voiced in the nineteenth century campaign do not appear in arguments for protecting unborn life today. Yet, as I will show, gender-based judgments do continue to inform arguments for regulation of women's reproductive conduct; today these judgments can be articulated in the physiological modes of argument the campaign inaugurated.

In the following sections, I illustrate the persistence of physiological reasoning in popular antiabortion arguments and in legal arguments for regulating women's reproductive conduct. I then analyze several instances of fetalprotective regulation, posing questions about its incidence and structure that courts generally have not. This exercise reveals that judgments about women's roles can and do shape fetal-protective regulation-notwithstanding its apparent preoccupation with protecting the unborn. Engaging in this exercise reveals deep commonalities between fetal-protective regulation of the present and the antiabortion laws of the past that are obscured by habits of physiological reasoning the campaign engendered. It thus creates a conceptual foundation for reconsidering the question of abortion-restrictive regulation in a constitutional framework.

\section{A. Physiological Reasoning in Popular Antiabortion Arguments}

Objections to abortion voiced in popular debate today both resemble their nineteenth century precursors and differ from them in important ways. Unlike antiabortion arguments of the last century, which openly addressed concerns of family life, contemporary arguments against abortion seem to concern themselves almost exclusively with protecting the unborn. Yet many contemporary opponents of abortion reason about the unborn in ways

258. H.R. STORER, supra note 79 , at $80-81$.

259. Roe v. Wade, 410 U.S. 113, 116-17 (1973). 
that betray the influence of the nineteenth century campaign. The science of human development now provides a coherent framework for reasoning about the morality of abortion, one so compelling that it is possible to make claims about abortion that seem to have no roots in matters of religious faith or judgments about family life. Antiabortion arguments that are cast in this scientific tradition define the moral problem presented by abortion in the form of the question, "when does human life begin?" and answer it, "at conception." Considered in this analytical framework, there appear to be no significant differences between the embryo/fetus and a born person, or between abortion and murder. One reason why such arguments attach no moral significance to the facts that might distinguish the embryo/fetus from a born person and distinguish abortion from murder is that they scarcely notice them: They reason about abortion in "scientific" ways that ignore women's role in gestating human life.

Ever since physicians of the nineteenth century employed physiological arguments to attack quickening doctrine, it has been possible to reason about the embryo/fetus and the dynamics of human development in scientific ways that do not refer to the physical and social work of reproduction women perform. ${ }^{260}$ Thus, a recent editorial column in the New York Post urged readers to "rush out and buy a copy of Life to view the most spectacular series of photographs ever taken of the formation of a human being, from the moment of conception," asserting, without more, that "these pictures virtually render obsolete the whole abortion debate." 261 As the column explained:

Here, in graphic color, is living, thrilling, irrefutable proof that within hours of conception, a unique, distinctive human being has been formed. The magazine says that within 20 hours of conception, when the sperm enters the ovum, "the result is a single nucleus that contains an entire biological blueprint for a new individual, genetic information governing everything from the length of the nose to the diseases that will be inherited. ${ }^{262}$

As the Post editorial describes the embryo depicted in the photograph, it already is all that it might become, containing "an entire biological blueprint for a new individual" and so apparently capable of autonomous self-realization. Examining this photographic enlargement of the embryo, the Post assures its readers, settles all moral questions concerning abortion. ${ }^{263}$

Analyzing photographs like those described in the Post editorial and featured in the antiabortion film The Silent Scream, Rosalind Petchesky has observed, "[f]rom their beginning, such photographs have represented the fetus as primary and autonomous, the woman as absent or peripheral."264

260. See text accompanying notes 94-115 supra.

261. Ray Kerrison, Backdrop to Bush's Court Selection; Pictures Show What Abortion is About, N.Y. POST, July 25, 1990, at 2.

262. Id.

263. Id. ("Let Molly Yard, Faye Wattleton, Gloria Steinem, Mario Cuomo or Jesse Jackson look at these pictures and say that the destruction of a 21-day old 'fetus' is not the destruction of a human being.").

264. Rosalind Pollack Petchesky, Fetal Images: The Power of Visual Culture in the Politics of 
As the commentary in the Post editorial illustrates, this tendency is not limited to visual representations. Arguments against abortion often employ "objective" modes of reasoning about human development that scarcely refer to women's role in gestating and nurturing human life. Thus, an antiabortion pamphlet observes, "[n]othing has been added to the fertilized ovum who you once were except nutrition,"265 just as Horatio Storer once argued that the "total independence" of the unborn could be discerned in the fact that "its subsequent history after impregnation is merely one of development, its attachment merely for nutrition and shelter."266 In such physiological accounts of human genesis, all that women give to the work of bearing and rearing children and all that it exacts from them is utterly invisible, except as it might be part of the "nutrition" digested by the fertilized ovum in the course of its autonomous project of self-realization. Narratives of human genesis that omit reference to women's work as mothers are invoked to condemn the conduct of women who resist becoming mothers. Just as often, the embryo/fetus invoked in arguments against abortion appears to have no physical or social relation to women who seek abortions. ${ }^{267}$

In this respect, then, the nineteenth century campaign inaugurated traditions of reasoning about the unborn, the influence of which can still be seen in popular debate. By contrast, claims about women's roles that dominated arguments for criminalizing abortion in the past no longer find similar expression. Because it is no longer acceptable to speak about women as the physicians once did, and because it is now possible to speak about the unborn without seeming to refer to women, demands for criminalizing abortion today seem bereft of gender-role concerns. Yet when Representative Henry

Reproduction, 13 FEMINIST STUD. 263, 268 (1987); see id. at 263-71 (analyzing photographs in popular media dating back to 1962 ).

265. J. WILLKE, DID YOU KNOW (n.d.) (antiabortion pamphlet), quoted in Olsen, supra note 5 , at 128 . The observation quoted in text is a reply to the following queries:

Did you "come from" a human baby? No! You once were a baby.

Did you "come from" a human fetus? No! You once were a fetus.

Did you "come from" a fertilized ovum? No! You once were a fertilized ovum.

A fertilized ovum? Yes! You were then everything you are today. Nothing has been added Id. to the fertilized ovum who you once were except nutrition.

266. H. STORER \& F.F. HEARD, supra note 95 , at 10-11.

267. For example, when a reader complained that journalist Nat Hentoff failed to grasp the offensive attitudes toward women underlying abortion-restrictive regulation, Hentoff published the following reply:

There is a new medical book, The Unborn Patient: Prenatal Diagnosis and Treatment, published by W.B. Saunders, a textbook firm in Philadelphia, which is a subsidiary of Harcourt Brace Jovanovich. As the book clearly and abundantly demonstrates, the fetus is also a patient. I am for free speech in all contexts, and $I$ am against killing. That is my mindset.

Nat Hentoff, VillaGe VoICE, July 9, 1991, at 6 (reply to reader letter) (reproduced in full). Compare id. with Petchesky, supra note 264, at 271 ("Along with the external political and cultural pressures, traditional patterns endemic to the male-dominated practice of obstetrics help determine the current clinical view of the fetus as 'patient,' separate and autonomous from the pregnant woman.") and Barbara Katz Rothman, The Tentative Pregnancy: Prenatal Diagnosis AND THE FUTURE OF MOTHERHOOD 114 (1986) ("[T]he fetus in utero has become a metaphor for 'man' in space, floating free, attached only by the umbilical cord to the spaceship. But where is the mother in that metaphor? She has become empty space."). 
Hyde passionately argues that "that tiny little atom of humanity surrounded by a wom[a]n called 'mother' is a member of the human family," 268 his comments suggest that tacit assumptions about "the wom[a]n called 'mother" " and her role in the "human family" may still inform judgments about the morality of abortion, despite their apparent focus on the unborn. Indeed, when opponents of abortion call "that tiny little atom of humanity" a "baby," and condemn the practice as murder, killing, or the destruction of human life, they are in fact expressing a moral judgment about a relation between mother and child, and condemning women for violating the most fundamental conceptions of the maternal role. ${ }^{269}$

In Abortion and the Politics of Motherhood, ${ }^{270}$ sociologist Kristin Luker analyzes the ways in which the abortion debate reflects conflicts about women's role as mothers, tracing value judgments about protecting unborn life to value judgments about the structure of family life. ${ }^{271}$ Examining a group of female activists on both sides of the abortion debate, Luker illustrates how divergent modes of reasoning about the unborn correlate with divergent modes of reasoning about the nature of sexuality, work, and family commitments in women's lives. Analyzed from this perspective, the abortion debate can be seen as a conflict between those who see "motherhood as the most important and satisfying role open to a woman," and those who see "motherhood [as] only one of several roles [open to women], a burden when defined as the only role."272 Recent poll data supports Luker's characterization of the controversy. The Los Angeles Times described the world view of abortion opponents it surveyed in the following terms: They "[f]]eel the country is in a state of moral decline and hold conservative views on 'family values." "273 It reported that while "[t]he majority of people who support abortion think that raising children can hold back a woman in her career. . . , [t] the majority of those who oppose abortion believe that mother-

268. 137 CoNG. REC. H5125 (daily ed. June 26, 1991) (remarks of Rep. Hyde).

269. If opponents of abortion in fact believe that the embryo/fetus is a baby and that abortion is murder, then they are accusing mothers of murdering their own children, a charge with explosive gendered import. Cf. J. MoHR, supra note 65, at 169 (1871 report for Iowa State Medical Society attacking abortion, asking what would become of the country when "American women ... for selfish and personal ends, butcher or poison their children?").

Yet, to my knowledge, opponents of abortion are not seeking to prosecute women for murder. Cf. note 233 supra (similar reticence in nineteenth century). It seems more reasonable to assume that the assertion "abortion is murder" is a context-specific judgment, a way of expressing outrage or repugnance at the violence of abortion itself. Cf. George Skelton, Most Americans Think Abortion is Immoral, L.A. TIMES, Mar. 19, 1989, available in LEXIS, Nexis Library, MAJPAP File, at 3. (poll finding that 57\% of Americans think that abortion is "murder," but also finding that 74\% of respondents agreed with the statement, "I personally feel that abortion is morally wrong, but I also feel that whether or not to have an abortion is a decision that has to be made by every woman for herself."). Of course, if the murder charge is a context-specific way of reasoning about abortion, it is quite specifically a judgment about women's conduct.

270. K. LUKER, supra note 65 .

271. See id. at 192-215; id. at 193 ("abortion debate is so passionate and hard-fought because it is a referendum on the place and meaning of motherhood") (emphasis omitted).

272. Id. at 214.

273. Skelton, supra note 269, at 6 ("To them, a woman's place is in the home and motherhood must always be a woman's most important and satisfying role."). 
hood should be the most important, satisfying thing a woman does."274 Related value judgments are expressed in opinion polls asking Americans to identify circumstances in which they believe women are justified in seeking an abortion. While Americans do countenance abortion in many circumstances, few believe that women are justified in seeking an abortion when they are attempting to pursue a career other than motherhood, with only 26 percent agreeing that a woman has a legitimate reason for seeking an abortion if the pregnancy threatens her education or employment opportunities. 275 This same assumption that motherhood is women's primary role is expressed when critics of the abortion right scorn women who seek abortion "on demand," "as a mere convenience," or for "no reason at all"-treating a woman's decision not to commit her body and her life to the work of bearing and rearing a child as an expression of petty expedience or self-indulgence, just as nineteenth century doctors claimed. ${ }^{276}$

Thus, even if the contemporary abortion debate lacks the open discussion of women's duties that marked the nineteenth century campaign, there is indeed evidence that concerns about women's conduct as mothers may lie just beneath its surface. Those who seek to protect unborn life want to regulate the conduct of women who fail to act as good mothers should. 277 Judgments about women's conduct as mothers are expressed by those interested in protecting unborn life outside the abortion context, as well. Thus, one commentator surveying a hospital ward of babies born to drug-dependent women angrily warned his readers that "[t]he sins of the mothers are apt to become the burden of society for generations to come,"278 and then applauded a female journalist and six other women who had volunteered to

274. Id. at 5 .

275. In a recent New York Times poll, respondents indicated that a pregnant woman should be allowed a legal abortion in the following circumstances: if the woman's health is seriously endangered by pregnancy ( $87 \%$ yes; $7 \%$ no); if there is a strong chance of serious defect in the baby (69\% yes; $21 \%$ no); if the family has a very low income and cannot afford any more children (43\% yes; $49 \%$ no); if she is not married and does not want to marry the man ( $42 \%$ yes; $50 \%$ no); if the pregnancy interfered with work or education (26\% yes; $65 \%$ no). E.J. Dionne, Poll on Abortion Finds the Nation is Sharply Divided, N.Y. TIMES, Apr. 26, 1989, at A1; see also text accompanying note 399 infra (reporting similar results in a poll of Louisiana residents).

276. Cf. Doe v. Bolton, 410 U.S. 179, 221 (1973) (White, J., dissenting) (Court's decision in Roe protects women's right to terminate a pregnancy for reasons of "convenience, whim, or caprice" or for "no reason at all"); Skelton, supra note 269, at 1 ("Americans adamantly object to abortion if its only purpose is birth control. . . . And they oppose it 'on demand,' as a mere convenience.").

During the nineteenth century, doctors also charged that women sought abortions for "shallow" reasons, of "inconvenience," "selfishness," or "laziness." Their objections were explicitly premised on the belief that, in avoiding the work of gestation and nurturance, wives vere "ignoring the demands of duty" and "neglecting the work God has appointed you to perform." See text accompanying notes 161-164 supra.

For an examination of the types of moral reasoning underlying women's decisions whether to terminate a pregnancy, see Carol Gilligan, IN A DifFerent VoICE: PSYChOlogical Theory AND WOMEN'S DEVELOPMENT 64-105 (1982).

277. Cf. Celeste Michelle Condit, Decoding Abortion Rhetoric 25, 26, 33, 106-07 (1990) (approval or disapproval of abortion often turns on whether the woman seeking an abortion appears to comport herself as a good mother).

278. Al Martine2, Babes in Machines and Babes in Arms, S.F. Chron., May 5, 1991, (Sunday Punch), at 2. 
hold the "damaged babies" with the exhortation, "Good for Victoria. Good for the women who cuddle babies."279

Interest in regulating women's conduct to protect the unborn is most prominently focused on the issue of abortion, about which public debate has raged since Roe, but it is by no means limited to matters of abortion. For example, state actors have begun to compel pregnant women to submit to surgical delivery and other physically invasive procedures for the benefit of the unborn. ${ }^{280}$ Despite the fact that few drug treatment programs admit pregnant women, an increasing number of state and local authorities are now prosecuting pregnant women whose drug use is deemed to threaten the unborn, and depriving women of child custody when their newborns test positive for drug exposure. ${ }^{281}$ Until Title VII of the Civil Rights Act was recently construed to prohibit the practices, many employers sought to exclude fertile women from employment believed to threaten the welfare of prospective generations. ${ }^{282}$ Pregnant women are now subject to public and private admonitions that their conduct may threaten the welfare of the unborn, ${ }^{283}$ receiving warnings which many advocates of the unborn would

279. Id.

280. See Veronica E.B. Kolder, Janet Gallagher \& Michael Parsons, Court-Ordered Obstetrical Interventions, 316 New ENG. J. MeD. 1192 (1987); Lawrence W. Nelson, Brian P. Buggy \& Carol J. Weil, Forced Medical Treatment of Pregnant Women: "Compelling Each to Live As Seems Good to the Rest," 37 Hastings L.J. 703, 704 (1986); Nancy K. Rhoden, The Judge in the Delivery Room: The Emergence of Court-Ordered Caesareans, 74 CAL. L. REv. 1951 (1986).

281. "Of about 7,000 drug treatment programs nationwide, only about 50 offer female patients child and obstetric care." Susan Diesenhouse, Drug Treatment is Scarcer Than Ever For Women, N.Y. TIMES, Jan. 7, 1990, at E26. In New York City, for example, a recent survey of 78 rehabilitative programs "found that 54\% exclude all pregnant women; 67\% do not accept pregnant women on Medicaid; and $87 \%$ do not treat pregnant women on Medicaid who are addicted to crack." Id.; see also note 344 infra (discussing shortage of prenatal care for women on public assistance). It is in this context that public officials are prosecuting drug-dependent women, and depriving women of child custody when their infants test positive for drug exposure. See Kary Moss, Substance Abuse During Pregnancy, 13 HARV. WomeN's L.J. 278 (1990) (prosecutions and custody deprivation); Bonnie I. Robin-Vergeer, Note, The Problem of the Drug-Exposed Newborm: A Return to Principled Intervention, 42 StaN. L. REv. 745 (1990) (custody deprivation). Pregnant drug-dependent women are also subject to "protective" incarceration, without being charged for a drug-related crime. See,e.g., Diesenhouse, supra, at E26 (state official admits that during 1989 over 100 pregnant, drug-dependent women were incarcerated in Massachusetts for one to thirty days without being charged for a crime because the state lacked treatment programs for them); Tamar Lewin, Drug Use in Pregnancy: New Issue for the Courts, N.Y. TIMES, Feb. 5, 1990, at A14 (discussing "protective" incarceration practices in South Carolina); see also United States v. Vaughn, 117 Daily Wash. L. Rptr. 441, 447 (D.C. Super. Ct. 1989) (judges in District of Columbia use sentencing discretion to detain pregnant, drugdependent women convicted for other reasons) (discussed in note 335 infra).

282. See, e.g., Mary E. Becker, From Muller v. Oregon to Fetal Vulnerability Policies, 53 U. CHI. L. REV. 1219, 1226, 1237-39 (1986); Wendy W. Williams, Firing the Women to Protect the Fetus: The Reconciliation of Fetal Protection with the Employment Opportunity Goals Under Title VII, 69 GEo. L.J. 641 (1981). But see UAW v. Johnson Controls, Inc., 111 S. Ct. 1196 (1991) (prohibiting fetal-protective regulation of women's employment under the Pregnancy Discrimination Amendment to Title VII of the Civil Rights Act of 1964); text accompanying notes 302-329 infra.

283. See San Jose State University, Presidential Directive 90.02 (Sept. 12, 1990) (on file with the Stanford Law Review) (implementing the Drug Free Schools and Communities Act of 1989, P.L. 101-226, elaborating guidelines or "standards of conduct" for campus employees and students, specifying that "[a]ny consumption of alcohol by a pregnant woman presents health risks to her unborn child, and is thus discouraged"); see also note 332 infra (discussing alcohol warning statutes adopted by states and municipalities). 
translate into legally enforceable duties of care. ${ }^{284}$ Today, the medical profession continues to play an important, though less prominent, role in defining and enforcing these regulatory norms. ${ }^{285}$

Each of these expressions of regulatory interest has its own justifications and lineage. Considered cumulatively, however, they suggest that public interest in regulating women's reproductive conduct is indeed growing, in ways that seem to be in deep conflict with the sex-egalitarian norms currently endorsed by public law. ${ }^{286}$ Today, it is unlikely that state actors would direct women to subordinate their interests to the act of bearing or caring for children, forego nontraditional employment, or otherwise adhere to conventional norms of feminine conduct as advocates for reform did in the past. Yet, when such demands are cast as requirements for the protection of unborn and yet-to-be-conceived life, they are not merely acceptable; increasingly, they are unchallengeable. This is so because those interested in regulating the conduct of pregnant and fertile women do not openly impugn women's rights as equal citizens of this nation; rather, they insist that sexspecific regulation of women's conduct as parents is warranted for reasons specific to the physiology of the female body-to protect unborn life that women alone may bear. ${ }^{287}$ infra.

284. For arguments that the pregnant woman owes a duty of care to the unborn, see note 331

285. Medical textbooks present the fetus as the doctor's "second patient." See WiLliams OBSTETrics at xi (Jack A. Pritchard, Paul C. MacDonald \& Norman F. Gant eds., 17th ed. 1985). Doctors act on this understanding in ways that can lead to conflicts vith their female patients. For example, a survey of heads of fellowship programs in maternal-fetal medicine revealed that almost half approved of using the courts to force women who refused medical advice to submit to medical procedures that are potentially life-saving for the fetus; a quarter advocated state surveillance of women in the third trimester of pregnancy who stay outside the hospital system. See Kolder et al., supra note 280, at 1193-94. Medical professionals have provided public authorities with information on drug-dependent pregnant patients that will result in legal actions against them. See, e.g., Jan Hoffman, Pregnant, Addicted-And Guilty?, N.Y. TIMes, Aug. 19, 1990, (Magazine), at 33, 44; Kary L. Moss, Legal Issues: Drug Testing of Postpartum Women and Newborns as the Basis for Civil and Criminal Proceedings, 23 Clearinghouse Rev. 1406, 1409-11 (1990). Physicians have also played a key role in the adoption of fetal-hazards policies excluding fertile women from the workplace. See, e.g., UAW v. Johnson Controls, Inc., 886 F.2d 871, 875, 877-79 (7th Cir. 1989) (en banc) (medical professional is "one of the primary proponents of Johnson Control's fetal protection policy"), rev'd, 111 S. Ct. 1196 (1991). They have played a less visible, but no less significant, role in focusing medical research on female-mediated harms to the unborn, while tending to neglect research concerning male-mediated harms to the unborn, thus skewing the evidentiary record on which public policy decisions are made. See, e.g., Williams, supra note 282, at 655-65; cf. Sandra Blakeslee, Research on Birth Defects Turns to Flaws in Sperm, N.Y. TIMES, Jan. 1, 1991, at Al. While the medical profession as a whole does not oppose abortion, medical conceptualization of the fetus as a "second patient" and various fetal-imaging technologies developed for treating pregnant women play a prominent role in antiabortion advocacy. See Petchesky, supra note 264; see also note 267 supra. Many doctors now refuse to provice legal abortions, and stigmatize those who do, see Jane Gross, Opposing Abortion, More Doctors Seek Ethical Balance, N.Y. TIMES, Sept. 8, 1991, at A1, A12 (1985 study by American College of Obstetricians and Gynecologists reveals that more than two-thirds of the nation's gynecologists will not perform abortions); Gina Kolata, Under Pressures and Stigma, More Doctors Shun Abortion, N.Y. TIMES, Jan. 8, 1990, at A1.

286. See, e.g, Civil Rights Act of 1964, 42 U.S.C. $\$ \S 2000$ e to 2000e-17 (1988); Craig v. Boren, 429 U.S. 190 (1976).

287. See, e.g., United States v. Vaughn, 117 Daily Wash. Rptr. 441,447 (D.C. Super. Ct. 1989) (fetal-protective sentencing of cocaine-dependent pregnant woman, convicted for a misdemeanor of 
Thus, while it is no longer acceptable to impose sex-based obligations on women premised on their social role in family life, arguments premised on women's physical role in the reproduction of life supply reasons for imposing regulatory constraints on female citizens. Yet, the possibility that stereotypical conceptions of women's roles might find expression in regulation of women's reproductive conduct is not recognized in law because courts continue to reason about such regulation within physiological paradigms that have distant roots in the nineteenth century campaign.

\section{B. Physiological Reasoning in the Jurisprudence of Reproductive Regulation}

As Part I of this article illustrates, when the Court has reviewed regulation concerning matters of reproduction, it has discussed such regulation as if characteristics of women's bodies could explain or justify it, emphasizing that physical differences between the sexes supply "realistic," "objective," or "inherent" reasons for imposing sex-based limitations on women's civil rights. ${ }^{288}$ In this respect, the Court interprets the Constitution within the naturalistic paradigms first elaborated in Muller: "Many words cannot make this plainer. The two sexes differ in structure of body, in the functions to be performed by each. ... This difference justifies a difference in legislation ...."289 Thus, today, as in the past, physiological modes of reasoning about women are invoked to limit principles recognizing woman's commonality with man and equality to him. Indeed, this mode of reasoning about women seems to acquire cultural force as women's claims to equality acquire cultural force. ${ }^{290}$ With the appearance of modern equal protection doctrines forbidding discrimination on the basis of sex, arguments grounded in repro-

forging a check) ("It is true that defendant has not been treated the same as if she were a man in this case. But then a man who is a convicted rapist is treated differently than a woman."); Johnson v. Florida, 578 So. 2d 419, 420 (Fla. Dist. Ct. App. 1991) (conviction for delivery of controlled substance to a minor) (defendant "took cocaine into her pregnant body and caused the passage of that cocaine to each of her children through the umbilical cord after birth of the child, then an infant person. The statute was twice violated.").

288. See text accompanying notes 14-58 supra (discussing physiological naturalism in constitutional jurisprudence that concerns the regulation of women's role in reproduction, as exemplified by cases such as Roe, Geduldig, and Michael M.).

289. Muller v. Oregon, 208 U.S. 412, 422-23 (1908).

290. Relations of gender inequality can be justified by invoking social values or nature itself. When overtly patriarchal modes of reasoning about women lose persuasive force, interest in physiological modes of reasoning may grow-to ascertain, as it were, which aspects of sexual hierarchy will or ought persist by reason of "nature." Thus, in circumstances where political discourse conceptualizes the citizen in genderless terms, arguments from reproductive physiology may come to serve a particularly important role in articulating gender relations.

Thomas Laqueur and Carole Pateman have employed a dialectical model of this sort to describe how the genderless rational subject featured in Enlightenment social contract theory prompted reasoning about women based on "nature." See Thomas LAQueUR, MAKING SEX: BodY AND GENDer From the Greeks to Freud 196-97 (1990); cf. Carole Pateman, The Sexual CONTRACT 41 (1988). The model supplies a provocative framework for thinking about the relation of rights-expanding and rights-restricting regulation affecting women's status in the nineteenth century, see text accompanying notes 241-242 supra, and again in the present era. 
ductive physiology now constitute one of the strongest constitutional rationales for class-based regulation of women's conduct.

Physiological analysis of reproductive regulation is by no means limited to the constitutional context. Even when construing the federal statute that forbids pregnancy discrimination in employment, courts continue to evaluate reproductive regulation in physiological paradigms, rarely analyzing employer hostility to the pregnant employee in light of the traditional animus against "working mothers"-or any aspect of the social history of the workplace. ${ }^{291}$ So long as courts view the fundamental realities of reproduction as physical and not social, they will ignore ways in which assumptions about women's roles can prompt or structure regulation of the pregnant woman's conduct.292

If physiological reasoning still plays an important part in justifying diverse forms of reproductive regulation, it plays an especially pronounced role in the jurisprudence of fetal-protective regulation. To justify such regulation, it is wholly unnecessary to appeal to considerations of maternal duty -or of religion, class, and race-as physicians did a century ago. From the standpoint of law, the fact that unborn life exists from the point of conception is sufficient to explain social interest in protecting it, and the fact that women alone may gestate life provides a sufficient and unimpeachable reason for regulating their conduct. In law, it now appears a mere happenstance of nature that women's conduct must be regulated to protect unborn life-a "distinction ... based on the reality that only the female of the

291. Courts enforcing the Pregnancy Discrimination Act, 42 U.S.C. $\$ 2000$ e(k) (1988), have derived a formal equality rule from its second clause, which specifies that employers should treat pregnant employees the same as "other persons not so affected but similar in their ability or inability to work." Thus, under the PDA, courts still analyze pregnancy as a physiological condition, requiring employers to treat pregnant employees the same as other employees whose capacity to work is similarly physiologically impaired. See Reva B. Siegel, Note, Employment Equality Under the Pregnancy Discrimination Act of 1978, 94 YALE L.J. 929, 931-33 (1985); cf. UAW v. Johnson Controls, Inc., 111 S. Ct. 1196, 1206-07 (1991). Enforcement of the PDA in this fashion has produced a marked change in employment practices, but enforcement has proceeded without critical evaluation of the societal attitudes producing the pregnancy exclusions the amendment sought to remedy. Only in attempting to distinguish between policies accommodating and penalizing the pregnant employee under the PDA, has the Supreme Court begun tentatively to situate pregnancy discrimination within a social framework. See California Fed. Sav. \& Loan Ass'n v. Guerra, 479 U.S. 272, 284-90 (1987). Glimpses of this alternative conceptual framework also appear in the concluding paragraphs of the Court's recent decision concerning fetal-hazards regulation of women's employment. See text accompanying notes 327-329 infra.

292. For example, it will appear reasonable to exclude women from the workforce when matters concerning women's reproductive role are in issue because of the assumption that women's presence in the workforce is intermittent, subordinate to their role in childbearing, and, uitimately, inconsistent with it. Similarly, matters of reproductive physiology may appear to supply reasons to exclude the female employee whose persuasive force in fact derives from assumptions about the characteristics of the "normal" employee in a particular job category. Cf. UAW v. Johnson Controls, Inc., 886 F.2d 871, 879 (7th Cir. 1989) (en banc) (industrial health expert testifies that "I was never taught to place a reproductive female in the average work exposure of lead. And furthermore, before the 60s, to my knowledge, no women were working in lead exposures."), rev'd, $111 \mathrm{~S}$. Ct. 1196 (1991); Levin v. Delta Air Lines, 730 F.2d 994, 996 (5th Cir. 1984) ("[t]hrough Delta's early years of operation, flight attendants were obliged to be unmarried, and pregnancy-in or out of wedlockwas grounds for firing") (upholding employer's decisions to bar pregnant women as flight attendants for reasons of customer safety). 
human species is capable of childbearing."293 Or, as Roe put it: "The pregnant woman cannot be isolated in her privacy. She carries an embryo and, later, a fetus, if one accepts the medical definitions of the developing young in the human uterus. ... The situation therefore is inherently different" from all other privacy precedents. ${ }^{294}$

Physiological reasoning about reproduction presents women as "the female of the human species" or simply as "the human uterus," locating fetalprotective regulation within a frame of reference defined by women's bodies. This scientific perspective acquires legal authority precisely as it reveals the "true," "objective" facts of reproduction, none of which are social. Indeed, the more physiological analysis strips human reproduction of its social character, the more objective and non-normative this mode of reasoning about regulating women's reproductive conduct appears.

Legal analysis of fetal-protective regulation is further abstracted from social context by habits of reasoning dating from the nineteenth century campaign, which present the fetus as an object of public interest scarcely connected physically or socially to the woman bearing it. When the fetus is considered as an object of regulatory concern distinct and apart from the woman bearing it, it becomes possible to reason about regulating women's conduct without seeming to reason about women at all.

Consistent with this tradition, Roe and its progeny conceptualize the state's interests in restricting abortion as a benign exercise of regulatory authority to protect unborn life, not as coercive exercise of regulatory authority against the pregnant woman. In this framework, state action against the pregnant woman can be justified by reasoning about the characteristics of the unborn life she bears. The fact that a fertilized egg has the physiological potential to develop into a born person gives the state constitutionally cognizable regulatory interests in a pregnant woman. ${ }^{295}$ The fact that a fetus is "viable"-"capable of meaningful life outside the mother's womb"-paradoxically provides "logical and biological justifications" for compelling a woman to continue carrying it. ${ }^{296}$ When the maternal/fetal relation is con-

293. Johnson Controls, 886 F.2d at 883, rev'd, 111 S. Ct. 1196 (1991); see text accompanying notes 302-339 infra.

294. Roe v. Wade, 410 U.S. 113, 159 (1973) (citations omitted).

295. Id.

296. See id. at 163. In Roe and again in Webster v. Reproductive Health Servs., 492 U.S. 490 , 553 (1989) (Blackmun, J., concurring in part and dissenting in part), Justice Blackmun justifies prohibiting abortion at viability much as doctors once justified prohibiting abortion at conception: by describing the viable fetus in terms that emphasize the autonomy of unborn life and its separation from the woman bearing it. Compare Webster, 492 U.S. 490 with text accompanying notes 97-107 supra. Conceptualizing unborn life in this fashion makes it possible to justify abortion-restrictive regulation in terms that scarcely refer to the citizen at whom state power is directed.

Critics of the viability standard derive the state's interest in regulating women's reproductive conduct in terms similarly focused on the embryo/fetus. For example, Justice White has observed: The governmental interest at issue is in protecting those who will be citizens if their lives are not ended in the womb. ... The State's interest is in the fetus as an entity in itself, and the character of this entity does not change at the point of viability under conventional medical wisdom. Accordingly, the State's interest, if compelling after viability, is equally compelling before viability. 
ceptually disaggregated in this fashion, state actors can discuss regulation directed at the pregnant woman as if it merely concerned the fetus; ${ }^{297}$ and they can impose duties on the pregnant woman by invoking the rights of the fetus, for example, "the right to be born with a sound mind and healthy body."298

This mode of reasoning about the fetus, as if it were scarcely connected to a woman, is a mode of reasoning about women, one with a social history tied to the regulation of women's reproductive role. Yet, the possibility that gendered judgments might structure fetal-protective regulation is obscured by the physiological paradigms in which it is analyzed. Physiological reasoning deflects attention from the social context in which judgments about protecting unborn life are formed and enforced. Considered out of social context, it seems entirely reasonable to explain fetal-protective regulation as motivated by a concern for the unborn, just as it seems reasonable to require the pregnant woman to act in ways that benefit the unborn. Yet "reason" in such matters involves questions concerning women's roles and not simply their bodies, as a simple act of recharacterization demonstrates. The interest in potential life recognized in Roe can also be characterized as an interest in making women who are resisting motherhood carry a pregnancy to term. Similarly, the right of the unborn to begin life with a sound mind and healthy body can be characterized as a duty of the pregnant woman to conform with communal expectations of how a pregnant woman ought to act. $^{299}$ Fetal-protective regulation of women's conduct defines and enforces duties of motherhood; it remains a law of gender status although no overt gender-based reasoning is employed to justify it. ${ }^{300}$ Moreover, because judg-

Thornburgh v. American College of Obstetricians \& Gynecologists, 476 U.S. 747, 795 (1986) (White, J., dissenting); see also Webster, 492 U.S. at 519 (plurality opinion) ("[W]e do not see why the State's interest in protecting human life should come into existence only at the point of viability, and that there should therefore be a rigid line allowing state regulation after viability but prohibiting it before viability.").

297. See In re Smith, 128 Misc. 2d 976, 980, 492 N.Y.S.2d 331, 334 (Fam. Ct. 1985) ("this 'interest in potential life should extend to protection of the quality of life" ") (quoting John E.B. Myers, Abuse and Neglect of the Unborn: Can the State Intervene?, 23 DuQ. L. REV. 1, 19 (1984)).

298. See Molly McNulty, Note, Pregnancy Police: The Health Policy \& Legal Implications of Punishing Pregnant Women for Harm to Their Fetuses, 16 N.Y.U. REv. L. \& Soc. Change 277, 291 n.89 (1987-88); cf. Department of Social Servs. ex rel. Mark S. v. Felicia B., 144 Misc. 2d 169, 171, 543 N.Y.S.2d 637, 638 (Fam. Ct. 1989) ("natural justice ... requires recognition of the legal right of every human being to begin life unimpaired by physical, mental, or emotional defects resulting from the neglectful acts of the parent"). But cf. Stallman v. Youngquist, 125 Ill. 2d 267, 275-80, 531 N.E.2d 355, 359-61 (1988) (denying that such a general right exists in law, and warning that gender bias will inform its application to the maternal-fetal relation).

299. See, e.g., Stallman, 125 Ill. 2 d at 278 ("In what way would prejudicial and stereotypical beliefs about the reproductive abilities of women be kept from interfering with a jury's determination of whether a particular woman was negligent at any point during her pregnancy?").

300. Judicial reasoning about fetal-protective regulation reflects an uneasy awareness of this problem, which can be detected whenever courts attempt to justify fetal-protective regulation in social paradigms. When courts disaggregate the maternal-fetal relationship and reason about the regulation of the pregnant woman as if it involved a relation between two born persons, they employ gender-neutral analogies that treat the maternal-fetal relation as a relation between strangers, or alternatively, as a relation between parent and child. Rarely, if ever, will courts analyze the maternal-fetal relation as like (or part of) the mother-child relation, and so acknowledge its gender-based 
ments about women's obligations as mothers are forged in a society divided by class and race, fetal-protective regulation is subject to every form of bias that women in this society face. ${ }^{301}$

\section{Gender Bias in Fetal-Protective Regulation}

In reasoning about regulating women's conduct to protect the unborn, state actors continue to make judgments about the duties and obligations of motherhood, just as medical opponents of abortion did in the nineteenth century. Yet, because of the physiological paradigms that organize this area of law, their judgments are not subject to the scrutiny normally directed at state action imposing sex-specific obligations of parenting on women. Consequently, fetal-protective regulation is rife with diverse forms of bias.

At first glance, the physiological existence of the fetus and its susceptibility to real physical harm seem to dispel the possibility that fetal-protective regulation could reflect stereotypical or otherwise biased reasoning about women. But to assert that fetal-protective regulation is infected with diverse forms of bias, one need not contend that harms facing unborn life are illusory. The risk of harm to unborn life, and of bias against women in actions undertaken to prevent it, may each be real. To see how unexamined assumptions about women's obligations as mothers can shape fetal-protective regulation, it is necessary to consider the methods and resources this society employs to prevent harm to the unborn. Examining when and how this society intervenes in women's lives to protect the unborn illuminates the social logic of fetal-protective regulation, revealing many ways in which the focus and structure of such regulation reflect social judgments about women rather than simple regard for the unborn.

To appreciate the social logic of fetal-protective regulation, it is helpful to consider such regulation in several contexts. I begin by examining fetalprotective regulation of women in the workplace, because judicial analysis of such regulation has recently shifted from physiological paradigms to a framework that recognizes the possibility that such regulation may be sub-

character. This reticence reflects sex-equalitarian convictions or conventions that, superficially at least, distinguish modern arguments for fetal-protective regulation from those of the past century. But using gender-neutral analogies to analyze fetal-protective regulation hardly precludes genderbased judgments about the equities of the regulation, especially where the risk of such judgments is one that doctrines concerning reproductive regulation wholly disregard. When gender-neutral analogies are employed casually, as they often are, they may serve to obscure rather than constrain gender-based judgments about the impositions on women which are warranted to protect the unborn. See, eg., note 330 infra (examining justifications for forced caesareans).

301. A recent survey of hospitals in 18 states revealed that $81 \%$ of pregnant women subjected to court-ordered surgical treatment were black, Asian, or Hispanic; all women were treated in teaching-hospitals or were receiving public assistance. Kolder et al., supra note 280, at 1192, 1193. Similarly, surveys of prosecutions and of reporting practices in certain jurisdictions suggest that pregnant women of color have been disproportionately targeted for drug-related regulation. See Gina Kolata, Racial Bias Seen in Prosecuting Pregnant Addicts, N.Y. TIMES, July 20, 1990, at A10; Dorothy E. Roberts, Punishing Drug Addicts Who Have Babies: Women of Color, Equality, and the Right of Privacy, 104 HaRv. L. REv. 1419, 1421 n.6, 1432-36 (1991). For a discussion of the ways in which judgments rooted in relations of race and class may structure fetal-protective regulation, see text accompanying notes 337-341 infra. 
ject to gender bias. These important developments in employment discrimination law have wider legal implications.

\section{Fetal-hazards regulation in employment.}

Until the Supreme Court held in UAW v. Johnson Controls, Inc. ${ }^{302}$ that fetal-hazards regulation of women's employment was prohibited under the Pregnancy Discrimination Amendment to the Civil Rights Act of 1964, the Equal Employment Opportunity Commission and all federal circuit courts to consider the question ruled that an employer could exclude fertile female employees from hazardous workplaces to protect any offspring they might conceive. ${ }^{303}$ The Seventh Circuit opinion which the Court overruled in Johnson Controls illustrates how reasoning about fetal-protection policies in physiological paradigms can obscure their social logic.

In Johnson Controls, the Seventh Circuit ruled that the facts of reproductive physiology supplied an objective basis for an employer to exclude all fertile women, of any age and reproductive intention, from jobs at its battery plant which exposed employees to lead and from all other jobs with bidding, promotion, or transfer rights to such jobs ${ }^{304}$-even though the employer adopted lead-exposure rules for women more rigorous than Occupational Safety and Health Administration (OSHA) standards, while ignoring an OSHA finding that excessive lead exposure posed risks to the offspring of male as well as female employees. ${ }^{305}$ The court held that evidence on malemediated reproductive harms was sufficiently uncertain that an employer interested in protecting the offspring of its employees could focus special regulatory attention on women. ${ }^{306}$ Because compliance with OSHA standards would not eliminate all risk of harm to the offspring of female employees, the court ruled that an employer could exclude all fertile women from employ-

302. $111 \mathrm{~S}$. Ct. 1196 (1991).

303. While the EEOC and federal courts employed different frameworks for analyzing fetalhazards policies, they agreed that properly structured policies were permissible under Title VII. See id. at 1200-02 \& n.1.

304. UAW v. Johnson Controls, Inc., 886 F.2d 871, 886 (7th Cir. 1989) (en banc), rev'd, $111 \mathrm{~S}$. Ct. 1196 (1991). The policy was applied to any work environment having certain defined levels of lead exposure, as measured by air and blood samples. See id. at 876.

305. The policy applied to work environments with lead exposure levels substantially below OSHA's requirements. See id. at 876 n.7. OSHA recommended that men or pomen desiring children should be provided with respirators allowing them to reduce lead exposure to the levels at which the Johnson Controls' policy excluded women, because OSHA found that lead produced reproductive harms transmissible through both sexes. See id. at 917 (Easterbrook, J., dissenting) (" Male workers may be rendered infertile or impotent, and both men and women are subject to genetic damage which may affect both the course and outcome of pregnancy." ") (quoting 43 Fed. Reg. $52,953,52,966(1978)$ ).

306. The court discounted plaintiffs' evidence that lead toxicity was transmissible to the offspring of male as well as female employees on the grounds that the studies cited were performed on animals rather than humans and that studies on human males had established only "a correlation between male lead exposure and sperm shape," characterizing this evidence as "at best, speculative and unconvincing." Id. at 889 . Judge Easterbrook in dissent pointed out evidence the majority ignored, emphasizing that OSHA had ruled that lead toxicity was transmissible through both sexes, and that the American Public Health Association had taken the same position. See id. at 917-19 (Easterbrook, J., dissenting). 
ment to ensure that no woman would become pregnant while she had elevated levels of lead in her blood. ${ }^{307}$ In the court's view, Johnson Controls's decision to exclude nearly all women from most jobs at the plant was based on physical facts of sex, not social considerations of gender: "The convincing scientific evidence of this risk and the very serious consequences of this danger combine to make this health risk quite different from the concerns in Muller v. Oregon which we would currently characterize as stereotypical rather than real." 308 The court was confident that "the challenged [employment policy] is based upon the reality that only the female of the human species is capable of childbearing," 309 and repeatedly attributed the exclusionary employment policy to scientific facts regarding women's bodies rather than social judgments about women's roles.

There are in fact two ways in which social judgments about the maternal role shaped Johnson Controls's fetal-protection policy. Evidence of the first can be seen in the company's decision to focus its policy on women alone. As the Supreme Court observed: "The bias in Johnson Controls' policy is obvious. Fertile men, but not fertile women, are given a choice as to whether they wish to risk their reproductive health for a particular job."310 But even if we assume that there are sex-based differences in the character or magnitude of reproductive risks, and further assume that such differences could justify the company's decision to restrict only women's employment, there still remains evidence of gender bias in the structure of the policy the company applied to women.

A simple hypothetical illustrates that the policy the company applied to women reflects social assumptions about women's roles, and not merely physical facts about their bodies. New epidemiological studies are now tracing miscarriages and diverse forms of fetal injury to sperm that has been damaged by exposure to alcohol, opiates like heroin and methadone, gases used in hospital operating rooms, lead, solvents, hydrocarbons, metals, oils, paints, pesticides, and a variety of industrial chemicals. ${ }^{311}$ Employers who are concerned about protecting their employees' future offspring and who credit this emerging body of scientific evidence will have to consider restricting the employment of men as well as of women. But, with the benefit of this

307. Id. at $876 \mathrm{n} .7,878$. As the court explained:

Limitation of the fetal protection policy to women actually pregnant was found ineffective because there is the very definite possibility that lead exposure will occur between conception and the time the woman discovers her pregnancy. ... Limitation of the policy to women planning pregnancy also was not found to be a suitable alternative because of ... the frequency of unplanned or undetected pregnancies.

Id. at 878 .

308. Id. at 898 (citing authority emphasizing distinction between "sterotyped characterizations of the sexes" and "real ... differences between men and women").

309. Id. at 883.

310. UAW v. Johnson Controls, Inc., 111 S. Ct. 1196, 1202 (1991); cf. notes 305-306 supra and accompanying text (discussing evidence that the reproductive harms of lead exposure are transmissible through men and women both).

311. See, e.g., Blakeslee, supra note 285, at A1, A36; see also notes 305-306 supra (discussing similar findings by OSHA and American Public Health Association relied upon by plaintiffs in the Johnson Controls case). 
new research, would they ever consider excluding all fertile men of any age or reproductive intention from hospital operating rooms, auto body shops, or lead-exposed employment, as well as from any line of work with options of promotion or transfer to such jobs? The common sense answer to this question is no. If the employment of men were at stake, it would simply not seem reasonable to eliminate all risk of harm to unconceived life ${ }^{312}$ by removing all fertile men from jobs exposing them to reproductive toxins. Even if regulators were willing to impose restrictions on men's employment, they would still tolerate some risk of harm to employee offspring rather than limit the employment prospects of so large a class of men. Thus, whether or not Johnson Controls's decision to focus its fetal-protection policy on women reflected social assumptions about the maternal role, it is clear that the exclusionary policy the company applied to women was one that would never have been applied to men. ${ }^{313}$

Similarly, when the Seventh Circuit disparaged the evidence on malemediated reproductive harms, and then concluded it was reasonable for an employer to exclude all fertile women from lead-exposed employment, its decision was based on something more than the facts of reproductive physiology or even concern for the welfare of future generations. The Seventh Circuit judged it reasonable to exclude all fertile women from employment because the policy conformed with certain culturally specific assumptions about women: assumptions that define women's ends by their organs so that all women of any age and reproductive intention appear to be potentially pregnant; 314 that devalue women's employment on the premise that they are or should be supported by men; ${ }^{315}$ and that denigrate women's competence to make reproductive decisions that reconcile responsibilities to themselves and other family members, existing and potential. ${ }^{316}$ From this perspective the Seventh Circuit's reasoning in Johnson Controls does indeed reflect traditional gender role assumptions of the sort expressed in Muller v. Oregon. ${ }^{317}$ Both the opinion and the policy it sanctioned in fact tell us more about how this culture values women than the unborn.

Recasting this analysis in more general terms, it can be observed that those involved in designing and reviewing Johnson Controls's fetal-protection policy may well have been moved by a concern for the welfare of unborn generations, but they would not have acted as they did but for certain assumptions about the women the company sought to exclude from its work

312. This was what the Seventh Circuit sought to accomplish. See Johnson Controls, 886 F.2d at $878,892-93$ (discussing reasons for extending policy to the entire class of fertile women). Of course, the policy protects yet-to-be conceived children from only one potential source of injury, and may subject them to new risks of harm. See id. at 916-18 (Easterbrook, J., dissenting) (criticizing majority's risk assessment).

313. See, e.g., David A. Strauss, Discriminatory Intent and the Taming of Brown, $56 \mathrm{U}$. CHI. L. REv. 935, 956-57 (1989) (discussing the "reversing the groups" test as a method of demonstrating that a regulatory decision is infected by discriminatory bias).

314. Cf. notes 111-113 \& 123 supra and accompanying texts.

315. Cf. note 196 supra.

316. Cf. note 199 supra and accompanying text.

317. 208 U.S. 412 (1908); see text accompanying notes 248-254 supra. 
force. The possibility that Johnson Controls's fetal-protection policy was based on traditional assumptions about women's roles eluded the Seventh Circuit because it evaluated the policy in a framework focused on the physical, not social, relations of reproduction. When courts analyze pregnancy as if it were simply a physiological condition, the physical facts of reproduction will appear to supply reasons for regulating the conditions in which women reproduce because these facts can be marshaled to support judgments based on the social relations of reproduction. Like born children, unborn embryos and fetuses are subject to real and diverse risks of harm. Yet, the reality of this harm does not necessarily explain the ways this society chooses to regulate women's conduct.

This analysis does not, of course, identify the statutory grounds on which the Supreme Court overruled the Seventh Circuit in Johnson Controls. ${ }^{318}$ While the Court observed the "obvious" "bias" in the company's decision to give "fertile men, but not fertile women, ... a choice as to whether they wish to risk their reproductive health for a particular job,"319 it held that the fetal-hazards policy was prohibited by Title VII of the Civil Rights Act of 1964 as amended by the Pregnancy Discrimination Act of 1978, because the policy "explicitly classifies [employees] on the basis of potential for pregnancy," 320 and by sex as well. ${ }^{321}$ In the Court's view, concerns about the safety of third parties might justify a sex-based employment policy under the statute's bona fide occupational qualification (BFOQ) provisions, ${ }^{322}$ but only if such safety concerns were "occupational" in character ${ }^{323}$ and related to the " "essence" " or " "central mission of the employer's business." "324 Thus,

\footnotetext{
318. 111 S. Ct. 1196 (1991).

319. Id. at 1202.

320. Id. at 1203. The Court explained:

"The Pregnancy Discrimination Act has now made clear that, for all Title VII purposes, discrimination based on a woman's pregnancy is, on its face, discrimination because of her sex." In its use of the words "capable of bearing children" in the 1982 policy statement as the criterion for exclusion, Johnson Controls explicitly classifies on the basis of potential for pregnancy. Under the PDA, such a classification must be regarded, for Title VII purposes, in the same light as explicit sex discrimination.
}

Id. (citation omitted).

321. Id. ("Johnson Controls' policy is facially discriminatory because it requires only a female employee to produce proof that she is not capable of reproducing."); see also id. at 1204 ("Johnson Controls' policy 'does not pass the simple test of whether the evidence shows "treatment of a person in a manner which but for that person's sex would be different." ") (citations omitted).

The Court analyzed the terms of the exclusionary policy and held that they were facially discriminatory; to reach this conclusion, it was unnecessary to determine whether Johnson Controls had an adequate empirical basis for its policy or benign motives for adopting it. See id. ("The beneficence of an employer's purpose does not undermine the conclusion that an explicit genderbased policy is sex discrimination under $\S 703$ (a) and thus may be defended only as a BFOQ.") Justice Scalia took the same position in his concurrence. See id. at 1216 (Scalia, J., concurring).

322. See 42 U.S.C. $\$ 2000 \mathrm{e}-2(\mathrm{e})(1)$ (1988):

[I]t shall not be an unlawful employment practice for an employer to hire and employ employees ... on the basis of ... religion, sex, or national origin in those certain instances where religion, sex, or national origin is a bona fide occupational qualification reasonably necessary to the normal operation of that particular business or enterprise.

323. $111 \mathrm{~S}$. Ct. at 1204 .

324. Id. at 1205 (quoting Western Airlines v. Criswell, 472 U.S. 400, 413 (1985)). 
concerns about the safety of third parties such as co-workers or customers could justify a sex-based exclusion "because they went to the core of the employee's job performance." By contrast, the Court reasoned,

[t] he unconceived fetuses of Johnson Controls' female employees . . . are neither customers nor third parties whose safety is essential to the business of battery manufacturing. No one can disregard the possibility of injury to future children; the BFOQ, however, is not so broad that it transforms this deep social concern into an essential aspect of batterymaking. ${ }^{325}$

The Court found independent support for this conclusion in the statute's language: "[T]he PDA's amendment to Title VII contains a BFOQ standard of its own: unless pregnant employees differ from others 'in their ability or inability to work,' they must be 'treated the same' as other employees 'for all employment related purposes." "326

While the Court's holding in Johnson Controls depends on an act of statutory construction, prior cases demonstrate that the statute's language was not sufficient to compel the Court's decision. Concluding the Johnson Controls opinion, the Court itself suggested that its reading of the statute was rooted in larger socio-historical concerns:

Concern for a woman's existing or potential offspring historically has been the excuse for denying women equal employment opportunities. See, e.g., Muller v. Oregon[.] Congress in the PDA prohibited discrimination on the basis of a woman's ability to become pregnant. We do no more than hold that the Pregnancy Discrimination Act means what it says. ${ }^{327}$

In holding that "the Pregnancy Discrimination Act means what it says" in matters concerning fetal-hazards regulation of women's employment, the Court did more than adhere to the language of the statute. It followed the "plain meaning" of the statute, as courts before had not, because effective advocacy alerted it to a history of gender bias relevant to the exclusions at issue in the case. ${ }^{328}$ From this perspective, one can read the Court's holding that "the BFOQ ... is not so broad that it transforms ... deep social concern [about the risk of "injury to future children"] into an essential aspect of batterymaking" as a statement of wider legal and social import: Allowing employers to reduce the risk of injury to future children by excluding women from the workplace would perpetuate a tradition of gender-based reasoning about women that is at odds with the central policy concerns informing the Civil Rights Act. ${ }^{329}$

325. Id. at 1206.

326. Id. (quoting 42 U.S.C. $\$ 2000 \mathrm{e}(\mathrm{k})(1988)$ ).

327. 111 S. Ct. at 1210 (citing Muller, 208 U.S. 412 (1908)). "It is no more appropriate for the courts than it is for individual employers to decide whether a woman's reproductive role is more important to herself and her family than her economic role. Congress has left this choice to the woman as hers to make." Id.

328. See Becker, supra note 282 (comparing fetal hazards regulation of women's employment to the premises of the protectionist legislation sanctioned in Muller, 208 U.S. 412).

329. To understand the Court's statements about the importance of protecting employee offspring, it is crucial to situate them in doctrinal context. The only reason for determining whether a business concern is "essential" to an employer's enterprise under Title VII is to decide whether it is of sufficient importance to that business to justify a sex-based employment policy within the meaning 


\section{Other forms of fetal-protective regulation.}

If one takes the Court's historical cautionary seriously and examines the incidence and structure of fetal-protective regulation with a critical eye, the lessons of Johnson Controls can be applied outside the employment context. As Johnson Controls clearly illustrates, regulators may adopt particular means for protecting unborn life because social assumptions about the maternal role lead them to underestimate the impact of the regulation on women-a tendency that frequently can be detected in the justifications courts have offered for compelling women to submit to caesarian delivery or other physically invasive procedures for the benefit of the unborn. ${ }^{330}$ When justifications for regulating women on behalf of the unborn ignore, devalue, or discount the significance of women's work, liberty, or judgment in matters of motherhood, they reflect persisting status-based assumptions about the duties of motherhood. The impositions of fetal-protective regulation will be invisible, or appear "reasonable," precisely to the extent they conform to social expectations concerning the maternal role. ${ }^{331}$

of the BFOQ defense. See note 321 supra. Therefore, the Court's holding that protecting employee offspring is not essential to the operations of a business means only that such an objective is not a sufficient reason for limiting women's employment opportunities under Title VII. After Johnson Controls, businesses are still free to adopt gender-neutral policies that reduce the risk of harm to unborn employee offspring; indeed, they are subject to federal and state laws requiring them to do so. The Court's holding in Johnson Controls merely deprived them of one method of protecting conceived and yet-to-be-conceived fetuses: They cannot pursue this end by excluding pregnant or fertile women from the workplace.

The same policy concerns informing the Court's interpretation of the BFOQ standard inform its interpretation of the PDA. The Court emphasized that Congress adopted the PDA's "ability to work" standard to repudiate traditional business practices which excluded women from employment for reasons associated with their reproductive role. See Johnson Controls, 111 S. Ct. at 1206-07; see also id. at 1210 (quoted at text accompanying note 327 supra).

330. Courts have applied the doctrine that parents may not refuse needed medical treatment for their children to the case of a pregnant woman refusing physically invasive therapy for the unborn life she bears. See In re A.C. 533 A.2d 611, 616 (D.C. App. 1987) (discussing precedents), vacated en banc, 573 A.2d 1235 (D.C. App. 1990). This reasoning gives no weight to the fact that the procedure in question requires cutting open the parent refusing treatment. For the most part, courts have not identified as a relevant analogical inquiry whether parents (or other family members) can be forced by the state to submit to physically invasive medical procedures for the benefit of born children. But cf. In re A.C., 573 A.2d at 1243-44 (after judge ordered caesarian delivery that may have contributed to the death of a pregnant cancer patient, the reviewing court vacated opinion, observing that "courts do not compel one person to permit a significant intrusion upon his or her bodily integrity for the benefit of another person's health"). For an account of how courts undervalue women's interest in bodily integrity in such cases, see Lucinda M. Finley, Breaking Women's Silence in Law: The Dilemma of the Gendered Nature of Legal Reasoning, 64 NOTRE DAME L. REV. 886, 901 (1989).

331. For example, some proponents of fetal-protective regulation argue that the pregnant woman who chooses not to obtain an abortion assumes a duty to act in the best interest of the unborn life she bears. See, e.g., United States v. Vaughn, 117 Daily Wash. Rptr. 441, 442 (D.C. Sup. Ct. 1989); McNulty, supra note 298, at 291-92 \& n.91; John A. Robertson, Procreative Liberty and the Control of Conception, Pregnancy, and Childbirth, 69 VA. L. REv. 405, 438 (1983) ("The mother has, if she conceives and chooses not to abort, a legal and moral duty to bring the child into the world as healthy as is reasonably possible .... [O]nce the mother decides not to terminate the pregnancy, the viable fetus acquires rights to have the mother conduct her life in ways that will not injure it.") (footnote omitted); cf. Johnsen, From Driving to Drugs, supra note 6, at 191-93 (discussing the wide variety of daily activities affected by this duty). Even if a woman's failure to obtain an abortion can be construed as an affirmative choice to continue the pregnancy, it does not follow from 
Similarly, assumptions about women's special responsibilities as mothers may produce regulatory strategies that single out the conduct of pregnant women for intensive social scrutiny. Women's unique physical role in reproduction identifies them as special conduits of harm to children so that pregnant women appear as a threat to the unborn life they are gestatingsometimes the only threat to children's welfare. Thus, many states now require liquor sellers to post signs warning pregnant women not to drink, yet do not require liquor sellers to warn men (or women) of the vast array of other harms that their drinking may pose to family members and strangers alike. ${ }^{332}$ Here, as in Johnson Controls, selective regulation of women's conduct is justified on the grounds that pregnant women have a unique physical capacity to harm children, when the regulation may in fact reflect the view that pregnant women have a unique social obligation to protect children. This would seem to explain why pregnant women have been forced to submit to surgery for the fetus in utero, when family members are not required to submit to surgery for each other's benefit; ${ }^{333}$ or why regulators have prosecuted women for acts of fetal neglect while ignoring the conduct of husbands who batter them during pregnancy. ${ }^{334}$ In these and other cases,

this choice alone that she assumes an obligation to "conduct her life" in ways that serve the interests of the unborn. Imposing this duty on the pregnant woman seems reasonable because we assume that mothers should live "for" their children; the argument acquires its persuasive force from unarticulated assumptions about the maternal role. See, e.g., note 333 infra (forced surgery); $c f$. Stallman v. Youngquist, 125 Ill. 2d 267, 273-80 (1988) (rejecting negligence claim asserted by child against mother for acts she took during pregnancy on the grounds that the claim reflects stereotypical views of women's roles). Concepts of consent have long been used to justify laws enforcing gender status roles. See note 362 infra and accompanying text.

332. See, e.g., MiNN. STAT. $\$ 144.3871$ (1990); 1991 N.Y. Laws, ch. 57. Drinking by pregnant women, in amounts which are as yet undetermined, may cause fetal alcohol syndrome. New research suggests that drinking may also cause male-mediated reproductive harms. See text accompanying note 311 supra. But one need not credit this evidence to discern the selective bias of alcohol warning statutes. Alcohol causes a range of social problems more prevalent than fetal alcohol syndrome, such as traffic accidents, economic deprivation, and diverse forms of neglect, abuse, and violence.

The Assembly sponsor of New York's alcohol warning statute, John Brian Murtaugh, justified that state's decision to warn only pregnant women of the dangers of drinking on the grounds that pregnant women have a "special responsibility." Kevin Sack, Unlikely Union in Albany: Feminists and Liquor Sellers, N.Y. TIMES, Apr. 5, 1991, at B1. "There certainly are other alcohol-related problems you could talk about," " Murtaugh observed, " '[b]ut if you put all of them on a poster you would dilute the message." "Id.

333. See In re A.C., 573 A.2d at 1243-44 (doctors must obtain patient's informed consent to perform surgery; similarly, they must obtain consent to perform an operation on one family member that will save the life or health of another, such as skin grafts or bone marrow transplants); see also note 330 supra.

A latent premise of the forced surgery cases seems to be that a normal mother would do anything for her children, and if she does not, can be made to. See In re A.C., 573 A.2d at 1257 n.7 (Belson, J., concurring in part and dissenting in part) ("The vast majority of women will accept significant risk, pain, and inconvenience to give their babies the best chance possible. One obstetrician who performs innovative fetal surgery stated that most of the women he sees 'vould cut off their heads to save their babies." ") (quoting Rhoden, supra note 280, at 1959); In re A.C., 573 A.2d at $1251 \mathrm{n} .21$ ("the welfare of the fetus is of the utmost importance to the majority of women; thus only rarely will a conflict arise") (citations omitted).

334. In two recent cases in which pregnant women were prosecuted for fetal abuse, the women involved appear to have been battered by their husbands during their pregnancies. See Johnsen, From Driving to Drugs, supra note 6, at 210 ("Ms. Stewart may have been a battered woman; the 
mothers are held to higher standards of self-subordinating conduct than fathers; women's breach of these exacting standards excites social rage in ways that men's breach of lesser standards does not. Thus, men may abandon children they "father," failing to participate in their care or economic support in a fashion that compromises a child's welfare just as surely as any act of maternal neglect, yet their conduct does not elicit communal retribution of the sort faced by pregnant women judged neglectful today. ${ }^{335}$

There are other types of selectivity evident in fetal-protection policies, which often single out for regulation certain groups of women who may deviate from cultural expectations of "normal mothers." For example, fetalhazards exclusions have been directed at women in male-dominated sectors of the work force, although reproductive toxins are not limited to those areas of the work force. ${ }^{336}$ Hospitals have adopted automatic drug testing procedures for pregnant women who receive public assistance or lack prenatal

police were called ten to fifteen times over one year to respond to violence directed at Ms. Stewart and her mother-in-law by Mr. Stewart."); Lewin, supra note 281, at A14:

[A] Wyoming judge dismissed child abuse charges against Diane Pfannenstiel, a pregnant 29-year-old who had gone to the police to report that she had been beaten by her husband. She then went to the hospital emergency room for treatment, but was arrested there and charged with abusing her unborn child by being intoxicated. The judge dismissed the charges because, he said, no harm to the fetus had been shown.

335. For example, in United States v. Vaughn, 117 Daily Wash. L. Rptr. 441 (D.C. Super. Ct. 1989), a judge incarcerated a pregnant woman who was before him on misdemeanor forgery charges, for the duration of her pregnancy when he discovered that she had been using cocaine. When she became eligible for release under an emergency overcrowding order, the judge still insisted on detaining her, offering this physiological justification for his gender-selective sentencing practices:

It is true that defendant has not been treated as if she were a man in this case. But then a man who is a convicted rapist is treated differently from a woman. She has also not been treated the same as a nonpregnant woman. But Ms. Vaughn became pregnant and chose to bear the baby who, like most criminal defendants the court sees so frequently, will start life with one other severe strike against it-no father is around. Arguably Ms. Vaughn should have demonstrated even greater responsibility toward her child. Id. at 447. As the comparison of Vaughn to "a man who is a convicted rapist" suggests, the judge is "horrified," id., at Vaughn's conduct. Here and elsewhere he openly chastises Vaughn, blaming her for her addiction, her failure to obtain an abortion, and for the fact that she has been abandoned by the father of her child. The judge seems more "horrified" at Vaughn's breach of maternal conduct than concerned for her fetus, bluntly expressing indifference to whether incarcerating a pregnant woman in an overcrowded prison will in fact promote the welfare of the unborn life she bears. See id. ("It is ironic for her to complain she is unable to get the [nutrition] she craves while pregnant in jail when her real craving is a devastating drug."); $c f$. Loren Stein \& Veronique Mistiaen, Pregnant in Prison, The Progressive, Feb. 1988, at 18 (advocates for incarcerated pregnant women complain that the women receive grossly inadequate medical care, receive little exercise or fresh air, eat poorly, and are crowded into unsanitary cells, with the result that their miscarriage rates are substantially higher than normal; miscarriage rates are even higher for drug dependent women who are forced to detoxify by incarceration).

If the purpose of incarceration is not to protect the particular fetus the pregnant woman is carrying, but instead is to punish, deter, or rehabilitate the substance-dependent pregnant woman, any physiological justifications for this court's gender-selective sentencing practices would seem to be weak at best. Men who are addicted to drugs or alcohol, or who abandon their children, also pose grave risks to their children's physical, emotional, and material welfare, but nowhere in the Vaughn opinion does the judge indicate that he considers men's parental conduct in sentencing for unrelated crimes.

336. See Becker, supra note 282, at 1237-40. One can explain this discrepancy in either of two ways: employers saw their employees as engaging in acts contrary to the maternal role when they were working in areas of the industrial sector traditionally dominated by men, $i d$, or, employers 
care, although drug use is by no means limited to the poorer classes of society. 337 Along similar lines, accumulating evidence suggests that prosecutions of drug-dependent pregnant women have focused on women of color in rates disproportionate to their presence in the population or propensity for drug use. ${ }^{338}$ Where the class of women targeted for regulation is defined by criteria associated with norms of gender, race, or class, it is all the more likely that fetal-protection policy reflects tacit assumptions about the women whose conduct is regulated, rather than simple solicitude for the welfare of future generations. Openly normative judgments about women's maternal conduct that purport to rest on standards which are neutral with respect to matters of gender, race, and class may instead rest on unexamined normative assumptions about the group of women selected for regulation; these same assumptions may tacitly influence the means chosen to protect the unborn. Would this society so readily contemplate criminal prosecution, "protective" incarceration, or custody-deprivation as responses to maternal addiction if the policies were to be applied to privileged women rather than the poor? ${ }^{339}$ Examining the structure of fetal-protective regulation in light of its social incidence may reveal that regulators are deeply contemptuous of women whom they judge to have violated the maternal role, ${ }^{340}$ or, as Dorothy Roberts has argued, it may even reveal that those engaged in regulating the conduct of poor women (especially poor women of color) are hostile toward them because they are bearing children. ${ }^{341}$ In other words, today as in the past, judgments about motherhood in this society are delineated by class and race, as well as by sex.

judged it contrary to their self-interest to bar fertile women from working in predominantly female sectors of the workforce because it would raise the marginal cost of labor.

337. See Moss, supra note 281, at 294; Roberts, supra note 301, at 1432-33.

338. See note 301 supra.

339. Cf. Strauss, supra note 313 , at 956.57 ("reversing-the-groups" test). Examining the history of public welfare programs, Dorothy Roberts observes that "[t] $]$ he state has . . . been more willing to intrude upon the autonomy of poor Black families, and in particular of Black mothers, while protecting the integrity of white middle-class homes." Roberts, supra note 301, at 1441.

340. Proponents of fetal-protective regulation often exhibit extraordinary regard for the welfare of children and a striking lack of regard for the welfare of the women who bear them. See, eg., Hoffman, supra note 285, at 34 (" 'If the mother wants to smoke crack and kill herself, I don't care," [said a police sergeant], " 'Let her die, but don't take that poor baby with her.' ").

341. Public officials have adopted coercive policies to regulate a class of women who are generally not provided access to adequate prenatal care and drug treatment programs. See note 281 supra; note 344 infra. Nor is it clear that these policies actually redound to the benefit of children. See note 347 infra. Dorothy Roberts argues that current modes of regulating drug-dependent women should be analyzed as punishing women of subordinate social classes for having babies. See Roberts, note 301 supra, at 1445-50; id. at 1445 ("it is the choice of carrying a pregnancy to term that is being penalized"). Some advocates of fetal-protective regulation do in fact argue that the pregnant woman has assumed the duties, burdens, and penalties they would infiict on her because she has failed to obtain an abortion. See note 331 supra. Considered from this perspective, fetal-protective regulation can be understood as providing incentives for abortion, which at least some of its proponents may intend as a matter of conscious design.

Thus, some interest in fetal-protective regulation may reflect anxiety about underclass women reproducing, $c f$. text accompanying notes 137-145 supra (related concerns in the nineteenth century); Roberts, note 301 supra, at 1442-44 (discussing sterilization of women of color), while some regulation may reflect animus towards underclass women themselves, see id. at 1441 (discussing "stereotypes that blame Black mothers for the problems of the Black family'); note 340 supra. 
If one considers the variety of methods the state has at its disposal to promote the welfare of the unborn, it is easier to appreciate the substantial role that judgments about women play in defining the incidence and structure of fetal-protective regulation. The state can promote the welfare of the unborn in many ways-by means that subject women to state coercion in their capacity as mothers, or by means that support women in their efforts to bear and raise a healthy child. Supportive intervention may take various forms. For example, poverty contributes to this nation's unacceptably high infant mortality rates. ${ }^{342}$ Thus, a state may take measures reducing the effects of poverty on infant mortality, many of which may be sex-neutral. ${ }^{343}$ Or, the state may employ sex-specific means, such as providing pregnant women with food and access to prenatal education and health care. ${ }^{344} \mathrm{Al}$ ternatively, a state seeking to promote the welfare of the unborn may employ coercive sex-specific means. Prominent examples include forcing women to bear a child they do not want, compelling them to submit to physically invasive surgery on behalf of the unborn, or punishing them when they do not lead their lives in a fashion the state believes will enhance the physical welfare of the embryo/fetus.

In considering these alternative approaches to promoting the welfare of the unborn, it is important to observe that one policy goal can often be secured by diverse means. A state wishing to reduce the exposure of the un-

342. Each year in the United States nearly 40,000 babies die before reaching their first birthday. Robert Pear, 19 Cities Listed for Aid to Cut Infant Mortality, N.Y. TIMES, Mar. 8, 1991, at A10. The U.S. ranks eighteenth in the world in infant mortality; and the infant mortality rate in inner cities and the South is worse than that in such developing countries as Cuba, Costa Rica, and Panama. Helen M. Wallace, Infant Mortality, in Maternal and Child Health Practices 411, 412 (Helen M. Wallace, George Ryan, Jr. \& Allen C. Oglesby eds., 3d ed. 1988); Julie Johnson, Congress Shows Signs of Spending to Fight Infant Deaths, N.Y. TIMES, May 21, 1989, at E4.

Poverty status is the single strongest predictor of an infant's life prospects. The infant mortality rate among infants born to poor families is 1.5 to 3 times that of infants born to non-poor families. William S. Nersesian, Infant Mortality in Socially Vulnerable Populations, 9 ANN. REv. OF PUB. HEALTH 361, 365 (1988). Poverty and minority status are the major risk factors for low birth weight infants as well. Id. at 368. For example, babies born in Central Harlem are four times more likely to have very low birth weight than babies born in more prosperous New York neighborhoods. Elizabeth Rosenthal, Health Problems of Inner City Poor Reach Crisis Point; Illness Rates Skyrocket, N.Y. TIMES, Dec. 24, 1990, at A1, A9. Low birth weight is a major determinant of infant mortality in the U.S.; half of all infant deaths in the first year of life occur among low birth weight infants. Dorothy C. Howze, The Black Infant Mortality Rate: An Unequal Chance for Life, 9 URB. LEAGUE REV. 20, 21 (1985-1986). Low birth weight babies who survive also have an increased risk for a range of health problems, including neurodevelopmental handicaps, congenital anomalies, mental retardation, blindness, autism, and growth and development problems. Id.; COMMrTTEE TO STUDY the Prevention of Low Birthweight, institute of Medicine, Preventing Low BirTHWEIGHT 6-8 (1985).

343. Given the consistent correlation between community wealth and infant mortality and morbidity, see note 342 supra, any strategy of economic revitalization that targets an impoverished community will improve the life prospects of its offspring.

344. Presently, adequate maternity care is largely unavailable for poor or uninsured women. For example, in Los Angeles County, patients who use public clinics must wait as Iong as 19 weeks after requesting an appointment to get one. Fourteen of 58 counties in California have no state or federally funded clinic offering prenatal care, and 26 counties have so few obstetrics providers for the poor that pregnant women on public health insurance have virtually no access to services. Moss, supra note 285, at 1412. Similarly, in inner city clinics in New York, the typical wait to schedule a pediatric appointment is several months. Rosenthal, supra note 342, at A16. 
born to cocaine may offer drug-dependent pregnant women a place in a drug treatment program-or it may incarcerate any drug-dependent pregnant woman who comes to the attention of public health authorities and deprive women of child custody when their newborns test positive for drugs. State actors wishing to reduce the exposure of the unborn to lead can eliminate lead-based paint from the walls of public housing, implement requirements or incentives for similar treatment of private dwellings, and improve regulations governing auto emissions and employee exposure to toxic conditions in the workplace. ${ }^{345}$ Or, the state can pursue this same end by excluding (or permitting the exclusion of) fertile women from any job that presents a risk of lead exposure. In short, some strategies of fetal-protection impose the costs of protecting unborn life solely on women, while others distribute them across the community as a whole; some strategies control and punish women in their capacities as mothers, while others empower and assist women in their efforts to bear and rear healthy children. Various means of promoting the welfare of the unborn reflect dramatically different views of women, and have dramatically different effects on women's lives.

Absent careful scrutiny of regulatory judgments, unexamined assumptions about women's obligations as mothers will inevitably inform actions undertaken on behalf of the unborn. Given the profoundly gendered concerns that fetal-protective regulation implicates and the race and class status of the women at whom it is often directed, ${ }^{346}$ it seems altogether likely that fetal-protective regulation will assume coercive and punitive rather than supportive and facilitative forms-for reasons ultimately having nothing to do with the welfare of children or the physiology of reproduction. Regulators seeking to protect the unborn will impose extraordinary restraints on the lives of pregnant women without determining whether their actions in fact serve the welfare of children or are consistent with normal modes of regulating parental conduct. ${ }^{347}$ In these and other ways, they will burden women

345. Although Congress banned residential use of lead paint more than a decade ago, studies estimate that nearly 900,000 units of public housing, and some $\mathbf{4 0}$ million units of private housing, still have lead-based paint. William E. Schmidt, Lead Paint Poisons Children Despite 1971 Law on Removal, N.Y. Times, Aug. 26, 1990, at A1, A20. The U.S. Department of Housing and Urban Development reports that 20 million homes have excessive lead dust, peeling paint, or chippings, and 3.8 million of those homes are inhabited by children under the age of 7 . Steven Waldman, Lead and Your Kids, Newsweek, July 6, 1991, at 42, 44, 48. In urban areas, the problem is aggravated by emissions from automotive and industrial sources. One public health report indicates that $55 \%$ of poor, black, urban children under the age of 6 have elevated levels of lead in their blood. Schmidt, supra, at Al. Adults living in these environments are exposed to lead as well, in ways that can affect the health of offspring they bear. See Waldman, supra, at 47-48.

346. See note 301 supra.

347. Subjecting pregnant, drug-dependent women to "protective" incarceration and depriving women of child custody when their newborns test positive for drug-exposure, see note 281 supra, are often characterized as policies of fetal-protection, but it is not clear that such policies promote the welfare of children. Both regulatory responses quite predictably drive poor women out of a public health care system already grossly inadequate in providing normal prenatal care, $c f$. note 344 supra, and even the most minimal forms of drug treatment for pregnant women, cf. note 281 supra. In addition, incarcerating women presents substantial risks to any pregnancy, especially if it is highrisk, as those of drug-dependent women generally are. Cf. note 335 supra. Custody deprivation dismantles families and communities, injecting large numbers of children into an overburdened fos- 
as they would not men, and burden poor women as they would not those of means. Whether considering restrictions on women's employment or restrictions on abortion, they will underestimate the impact of fetal-protective regulation on women's lives, and offer physiological justifications for imposing costs on women that the community is in fact capable of sharing. They may well be tempted to single out women, especially the most vulnerable women in the community, for symbolic acts of control or punishment that demonstrate a concern for children's welfare, because controlling and punishing women is cheaper and easier than actually doing something substantial to improve children's welfare. One need not take the position that women are entitled to immunity in their conduct during pregnancy to demand that fetal-protective regulation be subject to the kind of scrutiny that will ensure it is the product of rational and responsible social deliberation. For this reason, review of fetal-protective regulation must proceed in a fashion that is attentive to its social incidence, animus, and impositions.

When the state imposes duties of motherhood on pregnant women, it employs public power to enforce a gender status role. Only by evaluating the burdens and obligations it imposes on women in a framework attentive to the social organization of reproduction, and not simply physical facts concerning gestation, can the constitutional legitimacy of fetal-protective regulation be determined. It is from this standpoint that I now turn to reconsider the constitutional question of abortion.

\section{REvisiting the CONSTITUTIONAL QUESTION OF ABORTION}

[T] he fetus in utero has become a metaphor for "man" in space, floating free, attached only by the umbilical cord to the spaceship. But where is the mother in that metaphor? She has become empty space. ${ }^{348}$

-Barbara Katz Rothman (1986)

Did [man] ever take in the idea that to the mother of the race, and to her alone, belonged the right to say when a new being should be brought into the world? Has he, in the gratification of his blind passions, ever paused to think whether it was with joy and gladness that she gave up ten or twenty years of the heyday of her existence to all the cares and sufferings of exces-

ter care system, where they may endure intermittent and transient placements for years. Both forms of regulation appear to be relatively effective methods of punishing women and relatively dysfunctional methods of protecting children. In fact, some public officials are now beginning to concede that policies separating mother and child do not ultimately redound to the welfare of children. For example, both New York and Los Angeles are now experimenting with rehabilitating addicted mothers rather than separating them from their children. See Joseph B. Treaster, Plan Lets Addicted Mothers Take Their Newborns Home, N.Y. TIMES, Sept. 19, 1991, at A1 (New York officials note that cost of intensive counseling for mother is far cheaper than foster care, and that this arrangement is better for the child and the family); James Willwerth, Should We Take Away Their Kids?, TIME, May 13, 1991, at 62, 63.

If incarceration and custody-deprivation are in fact maternal-punitive, rather than fetal-protective, then they demand careful evaluation in light of normal modes of regulating parental conduct. Cf. note 335 supra; Robin-Vergeer, supra note 281, at 759-60.

348. B.K. RotHMAN, supra note 267 , at 114 . 
sive maternity ${ }^{349}$

$$
\text { -Elizabeth Cady Stanton (1855) }
$$

For all the genuine empathy for women the Supreme Court brought to its decision to protect the abortion right in Roe $v$. Wade, ${ }^{350}$ the opinion reasons about the regulation of abortion within the premises of the legal regime it repudiated. Roe never recognizes the possibility that a state's decision to restrict access to abortion might reffect traditional assumptions about women's roles, or that such a law might enforce or aggravate inequalities in the status of the sexes. These possibilities are obscured by the physiological framework in which the Court analyzed the constitutionality of abortionrestrictive regulation.

Roe in fact derives the state's interests in regulating abortion from the history and traditions associated with its criminalization, and defines the circumstances in which the state can restrict abortion in a framework based on medical facts about gestation. ${ }^{351}$ Within this framework, Roe analyzes the state's interest in restricting access to abortion as a benign exercise of state power for the unborn, and not as a coercive exercise of power against women. Though the Court did explain why a woman had a constitutionally protected interest in terminating a pregnancy, the Court never analyzed the exercise of state power involved in compelling women to continue a pregnancy: It never examined the "state's interest in potential life" as an interest in forcing women to bear children or as a warrant to expropriate from women the labor necessary to make "potential life" into a person. Because the Court never analyzed the state's interest in protecting unborn life as an interest in forcing women to perform the work of motherhood, it opened the way for its critics to discuss the "interest in potential life" as a constitutionally benign regulatory interest, ${ }^{352}$ which $R o e$ had subjected to unreasonable, inappropriate, or illogical restraints. ${ }^{353}$ At the same time, the Court left women who sought to defend Roe in an untenable spot: To defend Roe, they disparaged the significance of unborn life, when they in fact objected to the

349. Letter from Elizabeth Cady Stanton to Gerrit Smith (Dec. 21, 1855), reprinted in 1 HisTORY OF WOMAN SUFFRAGE, supra note 186 , at 839,840 .

350. 410 U.S. 113 (1973).

351. Id. at $148-52$.

352. Cf. Thornburgh v. American College of Obstetricians \& Gynecologists, 476 U.S. 747, 793 (1986) (White, J., dissenting) ("[I]t seems apparent to me that a free, egalitarian, and democratic society does not presuppose any particular rule or set of rules with respect to abortion.").

353. Cf. id. at 795 (White, J., dissenting) ("The State's interest is in the fetus as an entity in itself, and the character of this entity does not change at the point of viability under conventional medical wisdom. Accordingly, the State's interest, if compelling after viability, is equally compelling before viability.") (footnote omitted); Akron v. Akron Ctr. for Reprod. Health, 462 U.S. 416, 458, (1983) (O'Connor, J., dissenting) ("The Roe framework, then, is clearly on a collision course with itself. ... As medical science becomes better able to provide for the separate existence of the fetus, the point of viability is moved further back toward conception."); id. at 461 (O'Connor, J., dissenting) ("[P]otential life is no less potential in the first weeks of pregnancy than it is at viability or afterward. ... The choice of viability as the point at which the state interest in potential life becomes compelling is no less arbitrary than choosing any point before viability or any point afterward."); Ely, supra note 2, at 926 ("Dogs are not 'persons in the whole sense' nor have they constitutional rights, but that does not mean the state cannot prohibit killing them."). 
"interest in potential life" as a regulatory interest in controlling their bodies and lives.

Only in Thornburgh v. American College of Obstetricians and Gynecologists, ${ }^{354}$ some thirteen years after Roe, did the Court begin to address the constitutional question in terms that broke sufficiently with Roe's physiological framework to situate the abortion decision and its regulation within a larger social context. Surveying the abortion legislation enacted and reviewed since Roe, Justice Blackmun began to analyze abortion-restrictive regulation as a coercive exercise of power against women: "The States are not free, under the guise of protecting maternal health or potential life, to intimidate women into continuing pregnancies."355 And in concluding its opinion in Thornburgh, the Court asserted for the first time that state regulation of abortion posed issues of equality for women. ${ }^{356}$ Yet despite the intimations of a new analytic framework that appear in Thornburgh, the Court never broke sufficiently from Roe's reasoning to elaborate upon them. The Court's opinion in Thornburgh does not explain what might be constitutionally problematic about using state power "to intimidate women into continuing pregnancies,"357 or why depriving women of choice in matters of abortion would "protect inadequately a central part of the sphere of liberty that our law guarantees equally to all." 358 No opinion addressed these questions until Justice Blackmun penned his angry dissent in Webster, describing abortion regulation as a matter of sex equality for women ${ }^{359}$-raising issues which, for the most part, the plurality opinion of Chief Justice Rehnquist chose to overlook. ${ }^{360}$

354. 476 U.S. 747 (1986).

355. Id. at 759. At several points in the opinion, the Court described ways in which abortion restrictions can involve abuse of public power and problems of sexual imposition. See, e.g., id. at 762 (Pennsylvania"s mandated informed consent dialogue "is not medical information that is always relevant to the woman's decision, and it may serve only to confuse and punish her and to heighten her anxiety, contrary to accepted medical practice") (footnote omitted); id. at 767 ("Pennsylvania's reporting requirements raise the specter of public exposure and harassment of women who choose to exercise their personal, intensely private, right, with their physician, to end a pregnancy.").

356. Id. at 772 ("Our cases long have recognized that the Constitution embodies a promise that a certain private sphere of individual liberty will be kept largely beyond the reach of government. That promise extends to women as well as men.") (citations omitted).

357. Id. at 759.

358. Id. at 772.

359. See Webster v. Reproductive Health Servs., 492 U.S. 490, 538 (1989) (Blackmun, J., concurring in part and dissenting in part) ("I fear for the liberty and equality of the millions of women who have lived and come of age in the 16 years since Roe was decided."). Only in Justice Blackmun's dissent is the social significance of the abortion decision described as "vital to the full participation of women in the economic and political walks of American life," id. at 557; only in this dissenting opinion is state action restricting abortion analyzed as a use of power against women and not merely for the benefit of the unborn - as regulation designed to "conscript a woman's body and to force upon her a 'distressful life and future," " id. (quoting Roe v. Wade, 410 U.S. 116, 153 (1973)).

360. Cf. id. at 521 (plurality opinion)

[The dissent's] suggestion ... that legislative bodies, in a Nation where more than half of our population is women, will treat our decision today as an invitation to enact abortion regulation reminiscent of the dark ages not only misreads our views but does scant justice to those who serve in such bodies and the people who elect them. 
To determine the constitutionality of abortion-restrictive regulation, it is necessary to evaluate a particular exercise of state power against women. An individual woman deciding whether to terminate a pregnancy will evaluate the morality of that act in light of her obligations to herself and others, including the unborn, if she conceptualizes the embryo/fetus as separate from herself. ${ }^{361}$ By contrast, a community deciding whether to adopt legislation restricting abortion must confront a question that she does not: whether it is appropriate to use state force against women to compel them to continue a pregnancy they otherwise would terminate. This question is often absent from deliberations about the morality or constitutionality of abortionrestrictive regulation, which are too often conducted as recapitulations of the decisional process in which an individual woman might engage. None of the Court's opinions since Roe has devoted serious consideration to this question. Does the Constitution allow the state to force women to bear children?

Abortion-restrictive regulation is state action compelling pregnancy and motherhood, and this simple fact cannot be evaded by invoking nature or a woman's choices to explain the situation in which the pregnant woman subject to abortion restrictions finds herself. A pregnant woman seeking an abortion has the practical capacity to terminate a pregnancy, which she would exercise but for the community's decision to prevent or deter her. If the community successfully effectuates its will, it is the state, and not nature, which is responsible for causing her to continue the pregnancy. Similarly, a woman's choice to engage in sexual relations is no longer significant as a cause of pregnancy, if she would terminate that pregnancy, but for the interposition of communal force. A woman's "choice" to engage in (protected or unprotected) sex may be relevant to the state's justifications for enacting abortion-restrictive regulation, but it does not absolve the state from responsibility for compelling the pregnancy of a woman it prevents from obtaining an abortion. Indeed, if nature or a woman's "choices" play a prominent role in the state's justifications for imposing motherhood upon her, such explanations will obscure the fact that the state's decision to enact abortion restrictions rests on social judgments about the pregnant woman, just as they obscure the fact that such restrictions are an act of communal force against her. The significant role that arguments about women's nature and choices have played in rationalizing abortion-restrictive regulation, today and in the past, ${ }^{362}$ should raise suspicions about them: Both types of explanations ex-

361. For an examination of the types of moral reasoning underlying women's decisions about whether to terminate a pregnancy, see C. GiLligaN, supra note 276, at 64-105. For one elaboration of a feminist morality bearing on the practice of abortion, see R.P. PETCHESKY, supra note 15, at $330-60$.

362. Consent-based arguments have long been used to justify gender status laws. For centuries, they were invoked to justify the disabilities imposed on a wife by the marriage contract. So, for example, a husband could not rape his wife because in consenting to marriage, she consented to sex. See People v. Liberta, 64 N.Y.2d 152, 164, 474 N.E.2d 567, 573, 485 N.Y.S.2d 207, 213 (1984) ("Lord Hale's notion of an irrevocable implied consent by a married woman to sexual intercourse has been cited most frequently in support of the marital [rape] exemption."), cert. denied, 471 U.S. 1020 (1985). Consistent with this tradition, claims of marital consent played a role in nineteenth century arguments against abortion. See D.H., supra note 134, at 201: 
press normative judgments about women, and do not eliminate the task of analyzing abortion-restrictive regulation as an act of state force against women.

When abortion-restrictive regulation is analyzed as state action compelling motherhood, it presents equal protection concerns that Roe's physiological reasoning obscures, concerns that can and should be identified more precisely than the Court described them in Thornburgh. Along with a growing number of commentators, ${ }^{363}$ I would like to explore this equality claim as the Court has not. Constitutional analysis of abortion-restrictive regulation need not be confined to an equal protection framework, ${ }^{364}$ but the history of such regulation suggests important reasons why such an inquiry should be an integral part of any constitutional review.

\section{A. Equal Protection Analysis: Some Preliminaries}

Since its decision in Brown v. Board of Education, ${ }^{365}$ the Court has employed the Equal Protection Clause to analyze class- or caste-based legislation, including caste-based regulation of women's conduct. ${ }^{366}$ From a historical perspective it is clear that abortion-restrictive regulation is caste legislation, a traditional mode of regulating women's conduct, concerned with compelling them to perform the work that has traditionally defined their subordinate social role and status. From a historical perspective, it is also clear that this society's reasons for enacting restrictions on abortion have been deeply entangled in its conceptions of women as mothers. In the

\footnotetext{
If you are not willing to accept the cares, labors, responsibilities, and duties, of married life, why did you enter into that state? You were not forced into it; but you voluntarily and deliberately assumed that relation, and now you have no right to attempt to escape from what you knew beforehand is one of its most natural consequences, and a duty you tacitly promised the State.
}

Cf. notes 181, 184-185 \& 193-195 supra and accompanying texts (nineteenth century physicians and feminists discussing abortion in the context of marital rape).

Today, proponents of abortion-restrictive regulation locate a woman's putative act of consent, not in her decision to marry, but in her decision to have sex. See text accompanying notes $402-403 \&$ 413 infra. They argue that the pregnant woman has a duty to bear children because she has chosen to have sex, just as some proponents of fetal-protective regulation argue that the pregnant woman has a duty to conduct her life in ways that serve the interests of the unborn because she has chosen not to have an abortion. See note 331 supra.

Arguments that derive duties of motherhood from women's choices acquire much of their persuasive force from traditional assumptions about women's obligations as mothers; these status obligations seem to be duties women voluntarily assume so long as some act of choice can be found to support the claim. For an analysis of the argument that women's choice to have sex justifies forcing them to bear children, see note 403 infra. For a general discussion of consent-based derivations of gender status norms, see C. PATEMAN, supra note 290.

363. See note 5 supra.

364. Abortion-restrictive regulation entails an extraordinarily invasive exercise of state power; its impositions are sufficiently diverse in their impact on women's lives that they can, in fact, be registered across several bodies of constitutional jurisprudence: as a problem of privacy, takings, punishment, servitude, or equal protection. See note 367 infra.

365. 347 U.S. 483 (1954).

366. Cf. Craig v. Boren, 429 U.S. 190 (1976) (gender-based legislation is subject to heightened scrutiny under the Equal Protection Clause); Plyler v. Doe, 457 U.S. 202, 217 n.14 (1982) (quoted at note 369 infra). 
nineteenth century, the physicians' arguments against abortion depended entirely on the fact that the state was regulating women-women's bodies, women's work, women's roles. It was in this framework that fetal life-saving by compelled pregnancy seemed reasonable. The same, I believe, is true in the present. Given the centrality of sex in defining the objects, impositions, and justifications for abortion-restrictive regulation, it is crucial to analyze restrictions on abortion from the standpoint of equal protection commitments, whether as a primary or complementary focus of constitutional review. Equal protection doctrine is the only body of constitutional jurisprudence explicitly skeptical about the rationality of gender-based judgments and specifically concerned with the justice of gender-based impositions. ${ }^{367}$

There are obvious doctrinal impediments to applying equal protection concepts to abortion-restrictive regulation. As this article has explored in some detail, the Equal Protection Clause as currently construed imposes virtually no restraints on state regulation of women's reproductive lives. Together, the Court's physiological view of reproduction and its formal conceptualization of equality and discrimination present formidable obstacles to equal protection analysis of restrictions on abortion. ${ }^{368}$ Yet, analyzed

367. It is in this respect that equal protection analysis of abortion-restrictive regulation differs from review under other bodies of constitutional jurisprudence. Nonetheless, it may well be entirely compatible with them. Equal protection and other constitutional arguments against abortion-restrictive regulation focus, as Roe did not, on the particular use of state power entailed in compelling motherhood.

For example, Jed Rubenfeld defines the right to privacy as "the fundamental freedom not to have one's life too totally determined by a progressively more normalizing state." Rubenfeld, supra note 5, at 784. From this perspective, the constitutionally offensive aspect of antiabortion laws is that they "produce motherhood: they take diverse women with every variety of career, life-plan, and so on, and make mothers of them all." Id. at 788. Similarly, commentators analyzing abortionrestrictive regulation from a Thirteenth Amendment perspective have emphasized that "[s]uch laws violate the Amendment's guarantee of equality, because forcing women to be mothers makes them into a servant caste, a group which, by virtue of a status of birth, is held subject to a special duty to serve others and not themselves." Koppelman, supra note 5, at 484; see also L. TRIBE, supra note 5, $\S 15-10$, at 1354 ("more than a play on words links [a woman's] forced labor with the concept of involuntary servitude"); $c f$. Regan, supra note 5, at 1619 (compelled pregnancy offends the "nonsubordination value ... at the core of the thirteenth amendment," and conflicts with an Eighth Amendment interest in "freedom from physical invasion or imposed physical pain or hardship"). What these arguments from privacy, Thirteenth and Eighth Amendment jurisprudence share in common with arguments rooted in equal protection values is a concern about the way restrictions on abortion employ public power against women to define and organize their lives.

Unlike arguments premised on other constitutional protections, however, an equal protection analysis of abortion laws will explore these concerns within a body of doctrine attentive to the risk of bias in public judgments about and impositions upon women. Because equal protection doctrine recognizes that women's secondary social status has long been enforced and justified through the institution of motherhood, it offers a doctrinal framework to ensure that when state actors make judgments about imposing maternal obligations on women, their reasoning is not distorted by stereotypical assumptions about women.

368. The Court has upheld reproductive regulation against equal protection challenge by a series of formal arguments that insulate it from the weight of concerns and commitments equal protection doctrine otherwise embodies. Geduldig v. Aiello, 417 U.S. 484 (1974), held that state regulation of pregnancy is not sex-based because such regulation does not categorically differentiate the class of women from the class of men. At the same time, in Michael M. v. Superior Court, 450 U.S. 464 (1981), the Court suggested that state regulation of pregnancy cannot discriminate on the 
in historical perspective, it is clear that restrictions on abortion are deeply at odds with the values and commitments informing constitutional guarantees of equal protection.

Two clusters of values define the branch of equal protection jurisprudence concerned with state action directed at politically insular or underrepresented groups. Antidiscrimination values are concerned with the reasoning of state actors, prohibiting them from acting on the basis of prejudicial or traditional habits of thought that deny the full humanity, individual worth, or dignity of members of particular social groups. Antisubordination values are concerned with the material and dignitary injuries inflicted on members of particular social groups by public actions premised on such prejudicial habits of thought. Both sets of values find expression in equal protection doctrine, ${ }^{369}$ but in differing degrees. While the case law is rich with diverse expressions of antisubordination values, the "mediating" principles of the Equal Protection Clause are cast in antidiscrimination terms, demanding heightened scrutiny of state action directed at certain protected groups to ensure it is free of prejudicial or stereotypical modes of reasoning about them. ${ }^{370}$ Doctrine is thus most visibly concerned with analyzing the judgments of public decisionmakers adopting class-based regulation, and less visibly concerned with analyzing the impact of such regulation on the members of social groups at whom it is directed. ${ }^{371}$

basis of sex-because such regulation pertains to a real and categorical difference between the sexes. See text accompanying notes 16-37 supra.

369. The doctrine of suspect classifications reflects both antidiscrimination and antisubordination values. As Justice Brennan explained in Plyler v. Doe, 457 U.S. 202 (1982), equal protection doctrine requires heightened scrutiny of some forms of legislative classifications because "[s]ome classifications are more likely than others to refiect deep-seated prejudice rather than legislative rationality in pursuit of some legitimate objective" and "[l] ggislation predicated on such prejudice is easily recognized as incompatible with the constitutional understanding that each person is to be judged individually and is entitled to equal justice under the law." Id. at $216 \mathrm{n} .14$. He then shifts focus from the character of a legislature's judgments to the harm that state action can inflict upon members of protected groups, observing that "[l]egislation imposing special disabilities upon groups disfavored by virtue of circumstances beyond their control suggests the kind of 'class or caste' treatment that the Fourteenth Amendment was designed to abolish." Id. at 217 n.14; $c f$. L. TRIBE, supra note $5, \S 16-21$, at 1514-21 (distinguishing and comparing antidiscrimination and antisubordination principles).

370. The doctrinal standards for determining when race- and sex-based state action offend equal protection are more concerned with the state's rationale for adopting the policy in question than its impact on a protected class. They adopt a "perpetrator" rather than "victim" focus. See note 425 infra and accompanying text.

371. For example, in Mississippi Univ. for Women v. Hogan, 458 U.S. 718 (1982), the Court held that a state could not maintain a school of nursing solely for women, because its single-sex admissions policy violated constitutional requirements of equal protection. In reaching this decision, the Court scrutinized the state's objective in adopting the challenged policy and the particular means chosen to pursue it to determine whether they reflected stereotypical reasoning about women. Yet, after conducting this inquiry, the Court announced its constitutional objections to the single-sex admissions policy in terms that focused on its impact on women: "Rather than compensate for discriminatory barriers faced by women, MUW's policy of excluding males from admission to the School of Nursing tends to perpetuate the stereotyped view of nursing as an exclusively woman's job." Id. at 729. It further noted that excluding men from the field might depress nurses' wages. Id. at 729 n.15. Rationales for the doctrine of suspect classifications similarly fuse concerns about the reasoning of state actors with concerns about the impact of state action on members of protected groups. See note 369 supra. 
I will examine abortion-restrictive regulation from both antidiscrimination and antisubordination perspectives, in the first instance considering the types of gender-based judgments that may inform its enactment, and in the second, its gender-based impositions on women as a class. My analysis gives substantial weight to federal equal protection precedent, without conforming to it in all particulars. In this way, I hope to explore concerns that should be part of any equal protection inquiry, yet are omitted from most doctrinal formulations of its terms. Ultimately, antidiscrimination and antisubordination perspectives on abortion-restrictive regulation must inform each other. The concern that stereotypical reasoning about women can play a role in a legislature's decision to enact abortion-restrictive regulation acquires special significance in view of injuries that such regulation inflicts on women; correspondingly, these injuries demand consideration in light of the types of gender-based judgments that may prompt legislatures to inflict them. In short, to understand why the Equal Protection Clause should condemn abortionrestrictive regulation premised on unexamined assumptions about women's obligations as mothers, it is necessary to examine how state action compelling motherhood injures women.

\section{B. The Antidiscrimination Inquiry}

In analyzing abortion-restrictive regulation from an antidiscrimination standpoint, I premise my discussion on the assumption that laws forbidding or impairing women's practical access to abortion are sex-based. I assume, as most commentators have, that when the Court revisits Geduldig v. Aiello, ${ }^{372}$ it should modify it to accord with the common social understanding and the amended terms of the Civil Rights Act of 1964, that regulation concerning women's capacity to gestate categorically differentiates on the basis of sex, and so is facially sex-based. ${ }^{373}$

Once abortion-restrictive regulation is classified as sex-based state action,

372. 417 U.S. 484 (1974).

373. For criticism of Geduldig, see Law, supra note 5, at 983-84. For discussion of the Pregnancy Discrimination Act, see note 28 supra. The Act itself treats employment policies implicating abortion as sex-based. See 42 U.S.C. $\$ 2000$ e(k) (1988).

The sex-based character of abortion-restrictive regulation is evident if one examines either the regulation's social impact or the intentions of legislatures enacting it. Women, who alone can gestate life, seek abortions; men, who cannot become pregnant, do not. Because laws restricting abortion subject women to state-compelled pregnancy, they shape the social horizons of every woman who believes herself capable of becoming pregnant. Thus, for reasons physiological and social, such regulation affects women's lives in ways it simply cannot affect men's. As importantly, today as in the past, legislators who adopt restrictions on abortion believe they are adopting policies to govern women's conduct; they are not interested in regulating the conduct of men except insofar as men are instrumental in effectuating women's decisions respecting abortion.

Abortion-restrictive regulation is categorically sex-based: It affects all women, not just pregnant women, and it is adopted with the intention of regulating the conduct of all women, not just pregnant women.

Because legislatures adopting abortion-restrictive regulation intend such policies to apply to women and not men, and because such regulation affects women as it does not men, abortion-restrictive regulation presents all the risks of gender bias and imposition which equal protection analysis is intended to preclude. $C f$. G. CALABRESI, supra note 5, at 101-02; Law, supra note 5, at 1003. 
prevailing equal protection doctrine subjects it to heightened scrutiny. To pass constitutional muster, the state's decision to regulate by sex-based means must be substantially related to the achievement of important governmental objectives. ${ }^{374}$ On the face of it, it seems that abortion-restrictive regulation should easily satisfy constitutional requirements. Preventing or deterring women from obtaining abortions is "substantially related" to the "important governmental objective" of protecting unborn life. Yet, the intermediate scrutiny standard the Court articulated in Craig v. Boren involves more than this formulaic inquiry. As the Court explained in Mississippi University for Women v. Hogan, "[a]lthough the test for determining the validity of a gender-based classification is straightforward, it must be applied free of fixed notions concerning the roles and abilities of males and females."375 For this reason, the Court examines legislation in two ways. First, it scrutinizes legislative purpose to determine "whether the statutory objective itself reflects archaic and stereotypic notions" about women. ${ }^{376}$ Second, as the Court explained in Hogan,

if the state's objective is legitimate and important, we next determine whether the requisite direct, substantial relationship between objective and means is present. The purpose of requiring that close relationship is to assure that the validity of a classification is determined through reasoned analysis rather than through the mechanical application of traditional, often inaccurate, assumptions about the proper roles of men and women. ${ }^{377}$

The Court has variously described the type of gender-based judgments the Equal Protection Clause proscribes. As Hogan explains it, the Equal Protection Clause prohibits legislation which embodies "archaic and stereotypic notions" about the sexes, or is premised on "traditional, often inaccurate, assumptions about the proper roles of men and women." Elsewhere the Court has held that the Equal Protection Clause forbids legislation resting on the view of women as the " "weaker sex' or . . . child-rearers,"378 and other " "old notions' of role typing,"379 including the assumption that "the female [is] destined solely for the home and the rearing of the family, and only the male for the marketplace and the world of ideas." "380 Thus, the Court's gender discrimination cases condemn state regulation premised on empirical generalizations and normative assumptions about the "roles of

374. See Craig v. Boren, 429 U.S. 190, 197 (1976).

375. 458 U.S. 718, 724-25 (1982).

376. Id. at 725. Even if the statutory purpose appears legitimate, the Court may inquire whether it is the actual purpose. Id. at 728 ("the mere recitation of a benign, compensatory purpose is not an automatic shield which protects against any inquiry into the actual purposes underlying the statutory scheme") (quoting Weinberger v. Wiesenfeld, 420 U.S. 636, 648 (1975)); see also City of Richmond v. J.A. Croson Co., 488 U.S. 469, 495 (1989) (plurality opinion).

377. 458 U.S. at 725-26.

378. Califano v. Webster, 430 U.S. 313, 317 (1977). (1975)).

379. Craig v. Boren, 429 U.S. 190, 198 (1970) (citing Stanton v. Stanton, 421 U.S. 7, 14

380. Hogan, 458 U.S. at 726 n.11 (quoting Stanton, 421 U.S. at 14-15); see also Craig, 429 U.S. at 198-99 (repudiating "increasingly outdated misconceptions concerning the role of females in the home rather than in the 'marketplace and world of of ideas' ") (quoting Stanton, 421 U.S. at 15). 
men and women,"381 especially the assumption that women are merely, primarily, or essentially mothers, persons "destined solely for the home and the rearing of the family." Though the Court has never analyzed reproductive regulation in light of these concerns, one need only look to the history of abortion-restrictive regulation to see that such regulation can be, and has been, premised on constitutionally proscribed judgments about women.

During the nineteenth century, legislation criminalizing birth control was enacted to enforce "traditional . . . assumptions about the proper roles of men and women," 382 and served as an important public mechanism for maintaining the sexual division of social life. Although laws prohibiting abortion and contraception were omitted from the account of "our $\mathrm{Na}$ tion['s] . . . long and unfortunate history of sex discrimination" Justice Brennan offered in Frontiero v. Richardson, ${ }^{383}$ they emanated from the same separate spheres ideology he condemned. ${ }^{384}$ Laws criminalizing contraception and abortion were explicitly premised on the view that women are "child-rearers," and that "the female [is] destined solely for the home and the rearing of the family, and ... the male for the marketplace and the world of ideas." "385 Indeed, the records of the nineteenth century campaign provide a textbook illustration of attitudes toward women the Equal Protection Clause now prohibits. The history of abortion-restrictive regulation suggests that there may be substantial equal protection impediments to renewed enforcement of pre-Roe abortion law. ${ }^{\mathbf{3 8 6}}$ And it supplies a compelling reason

381. The case law tends to conflate two types of improper bases for statutes: erroneous empirical generalizations about women, and offensive normative judgments about women. See, e.g., Hogan, 458 U.S. at 726 (rejecting legislation premised on "traditional, often inaccurate, assumptions about the proper roles of men and women") (emphasis added).

382. Hogan, 458 U.S. at 725-26; $c f$. Karst, Woman's Constitution, supra note 5, at 457:

Prominent among the means historically used to control women's sexuality and maternity has been the law. The range of controls can be called to mind just by reciting a list of legal topics: marriage, marital property, divorce, control over and responsibility for children, illegitimacy, abortion, contraception, prostitution, and rape.

Id. (footnote omitted).

383. 411 U.S. 677,684 (1973) (plurality opinion).

384. In describing the attitudes toward women that gave rise to the nation's "long and unfortunate history of sex discrimination," Justice Brennan quoted Justice Bradley's opinion in Bradwell v. Illinois: "The paramount destiny and mission of woman are to fulfill the noble and benign offices of wife and mother." "Frontiero, 411 U.S. at 685 (plurality opinion) (quoting Bradwell v. Illinois, 83 U.S. (16 Wall.) 130, 141 (1872) (Bradley, J., concurring)).

385. Hogan, 458 U.S. at 726 n.11 (quoting Stanton v. Stanton, 421 U.S. 7, 14-15 (1975)).

386. Many states still have pre-Roe abortion statutes on the books. See Frances Frank Marcus, Louisiana Lawyers Move to Revive Invalidated Law Banning Abortions, N.Y. TIMES, Oct. 7, 1989, at A9. Some statutes were enacted before women were even allowed to vote. See, e.g., TEx. Rev. Civ. Stat. AnN. art. 4512.5 (West 1976) (enacted 1911); Wash. Rev. Code AnN. $\$ \S 9.02 .010-.02 .030$ (West 1988) (enacted by Laws 1909, ch. 249, $\$ \S 196-198$ ). All pre-Roe statutes were enacted before the Court began applying modern equal protection analysis to sex-based regulation; consequently, the legislatures that adopted them were free to regulate women's conduct in ways that enforced traditional conceptions of women's roles. Such regulation was not condemned by a majority of the Court on equal protection grounds until the mid-1970s. See, e.g., Craig v. Boren, 429 U.S. 190, 197 (1976) (adopting standard of heightened scrutiny for sex-based state action).

Chief Justice Rehnquist has repeatedly observed that older legislation is more likely to rest on archaic gender-based assumptions than is legislation recently enacted. Cf. Rostker v. Goldberg, 453 U.S. 57, 74 (1981) (claiming recent congressional debate "clearly establishes that the decision to 
for scrutinizing currently enacted abortion legislation with extraordinary care to ensure that it is free from the attitudes and assumptions about women that attended its adoption in the past.

It may be claimed that the gender code informing the nineteenth century campaign was a product of its era, and that today a legislature might restrict access to abortion to protect the unborn without entertaining any similar assumptions about women. History alone cannot refute this objection. Yet, the historical record supplies strong evidence that this argument should not be readily credited. The nineteenth century campaign to restrict abortion was multi-purposed, simultaneously benign and pernicious in its objects: Opponents of abortion urged its regulation to protect unborn life and to enforce a certain gender code and to prevent depopulation of certain racial and ethnic groups. In reasoning about saving unborn life, advocates of antiabortion laws were simultaneously reasoning about women's lives. The genderbased framework in which legislatures reasoned about restricting abortion in the past provides a lesson for those charged with reviewing such regulation in the present. The existence of bona fide legislative concern to protect the unborn does not preclude the possibility that abortion-restrictive regulation is animated by constitutionally suspect purposes. Nor does it preclude the possibility that a legislature's decision to save fetal life by compelling pregnancy may ultimately depend on the attitudes toward women that legislators hold. I explore each of these equal protection objections in turn.

\section{Legislative purpose.}

Is the purpose of abortion-restrictive regulation a legitimate one? Roe describes a legislature's purpose in restricting women's access to abortion as protecting unborn life. Yet, from a social standpoint, that purpose can be differently described. A legislature's purpose in enacting restrictions on

exempt women from [draft] registration was not the 'accidental byproduct of a traditional way of thinking about females" ") (citations omitted); Michael M. v. Superior Court, 450 U.S. 464, 471 n.6 (1981) (plurality opinion) (similar inference drawn from fact that state legislature recently considered and rejected proposals to make statutory rape statute gender neutral); see also JoHN HART ELY, DEMOCRACY AND DISTRUST: A THEORY OF JuDICIAL REVIEw 167-69 (1980) (suggesting that older sex-based legislation warrants heightened scrutiny, and may be especially vulnerable to invalidation under the Equal Protection Clause).

Even legislation that does not employ suspect classifications can be invalidated on equal protection grounds if it was originally adopted with discriminatory purposes. See Hunter v. Underwood, 471 U.S. 222, 233 (1985):

Without deciding whether [the regulation] would be valid if enacted today without any impermissible motivation, we simply observe that its original enactment was motivated by a desire to discriminate against blacks on account of race and the section continues to this day to have that effect. As such, it violates equal protection under Arlington Heights.

There are, of course, concerns apart from equal protection that may militate against revival of pre-Roe abortion statutes. See, e.g., Weeks v. Connick, 733 F. Supp. 1036, 1039 (E.D. La. 1990) (because Louisiana's old "criminal abortion statutes and [post-Roe] abortion regulations clearly conflict, earlier statutes were repealed by implication"); Erica Frohman Plave, Note, The Phenomenon of Antique Laws: Can a State Revive Old Abortion Laws in a New Era?, 58 Geo. WASH. L. REv. 111, 111 (1989) (discussing "whether a state statute, once declared unconstitutional . . . may be validly enforced without legislative reenactment after a later decision overrules the prior holding of unconstitutionality"). 
abortion is to pressure or compel women to carry a pregnancy to term which they would otherwise terminate-as the Court has acknowledged in the funding cases. ${ }^{387}$

It is by no means clear that this legislative purpose is legitimate under equal protection doctrine. ${ }^{388}$ A legislature's effort to force women to bear children could easily be characterized as a "statutory objective [that] reflects archaic and stereotypic notions" 389 about women. Motherhood is the role upon which this society has traditionally predicated "gross, stereotyped distinctions between the sexes." 390 Thus, the objective of abortion-restrictive regulation is to force women to assume the role and perform the work that has traditionally defined their secondary social status. More particularly, the purpose of abortion-restrictive regulation appears constitutionally suspect if one considers (1) the role that stereotypes of women as "childrearers" played in the history of coerced childbearing (including laws criminalizing both abortion and contraception), (2) the role these same stereotypes played in justifying restrictions on women's participation in the workforce and the political arena ${ }^{391}$ during the era that federal and state law denied women access to abortion and contraception, ${ }^{392}$ and (3) the exclusions and indignities this society still inflicts upon women who gestate and nurture human life. ${ }^{393}$ Of course, state actors may well believe their interest in protecting unborn life justifies their interest in forcing pregnant women to bear children. But, as history attests, the fact that state actors believe they are justified in forcing women to bear children by no means precludes the possibility that they are acting from invidious attitudes about women-for example, an

387. The Court has described the legislature's purpose in enacting abortion-restrictive regulation as an interest in controlling women's conduct in the abortion funding cases, but not in cases involving direct prohibitions or constraints on abortion. Cf. Harris v. McRae, 448 U.S. 297, 325 (1980) ("By subsidizing the medical expenses of indigent women who carry their pregnancies to term while not subsidizing the comparable expenses of women who undergo abortions .... Congress has established incentives that make childbirth a more attractive alternative than abortion for persons eligible for Medicaid."); Maher v. Roe, 432 U.S. 464, 478-79 (1977) (state has a "strong and legitimate interest" in promoting childbirth over abortion) (quoting Beal v. Doe, 432 U.S. 438, 446 (1977)).

388. In the abortion funding cases, the Court acknowledged that legislatures sought to pressure women to bear children, see note 387 supra, but it never subjected this legislative purpose to heightened scrutiny or otherwise attempted to reconcile it with the concerns of sex discrimination doctrines because it did not view the legislative classifications as sex-based. See note 23 supra. In fact, the Court's discussion of legislative purpose in the abortion funding cases is remarkably cursory given that they involved no "compelling" state interest. According to Roe, the state's interest in potential life does not become compelling until viability. Roe v. Wade, 410 U.S. 113, 163 (1973).

389. Mississippi Univ. for Women v. Hogan, 458 U.S. 718, 725 (1982).

390. Frontiero v. Richardson, 411 U.S. 677, 685 (1973) (plurality opinion).

391. See, e.g., AILEen S. KRaditor, The IDEAS of the Woman SufFrage Movement, 1890-1920, at 15 (2d ed. 1981) (congressional opponents of women's suffrage rested their argument on the grounds that "each woman's vocation [was] determined not by her individual capacities or wishes but by her sex. Men were expected to have a variety of ambitions and capabilities, but all women were destined from birth to be full-time wives and mothers. To dispute this eternal truth vas to challenge theology, biology, or sociology."); text accompanying notes 248-257 supra (discussing justifications for protective labor legislation restricting women's employment).

392. See text accompanying notes $212-219$ supra.

393. See text accompanying notes $439-456$ infra. 
inability to comprehend that women are individuals whose lives are richer than society's reductive view of them and who will suffer in having this social status forced on them. Considered from an antidiscrimination perspective, the state's purpose in adopting restrictions on abortion is deeply suspect-if not illegitimate on its face.

It is crucial to consider this threshold objection to abortion-restrictive regulation before scrutinizing the regulation in more detail. Whatever weight one accords this constitutional concern at the outset, it acquires force as one examines the judgments that abortion-restrictive regulation can reflect about women and the particular forms of status harm it can inflict. Thus, because the purpose of abortion-restrictive regulation ultimately demands evaluation from an antisubordination perspective, $I$ intend to return to it and explore it at greater length below.

\section{Legislative means.}

Roe describes the purpose of abortion-restrictive regulation as protecting unborn life. If one follows this descriptive convention, compelled motherhood is not the purpose of abortion-restrictive regulation, but instead a particular means to a nominally benign legislative end. And on the face of it, this means-ends relationship satisfies doctrine's requirement of instrumental rationality: A state that seeks to protect unborn life by compelling women to continue pregnancies they wish to terminate employs means that are substantially and functionally related to important governmental ends.

Yet applying the Craig standard in this mechanical fashion will defeat the purpose of the inquiry, which is "to assure that the validity of a classification is determined through reasoned analysis rather than through mechanical application of traditional, often inaccurate assumptions about the proper roles of men and women."394 Examining the relationship between a legislature's ends and means will identify stereotypical reasoning where the legislature misattributes characteristics of some group members to the group as a whole, and thus employs "gender as an inaccurate proxy for other, more germane bases of classification." 395 But because a state's decision to save fetal life by compelling pregnancy entails a purely functional use of the pregnant woman, any traditional sex-role assumptions that may inform or prompt this regulatory decision cannot be detected by examining how

394. Mississippi Univ. for Women v. Hogan, 458 U.S. 718, 725-26 (1982); cf. City of Richmond v. J.A. Croson Co., 488 U.S. 469, 493 (1989) (plurality opinion):

[T] he purpose of strict scrutiny is to 'smoke out' illegitimate uses of race by assuring that the legislative body is pursuing a goal important enough to warrant use of a highly suspect tool. The test also ensures that the means chosen 'fit' this compelling goal so closely that there is little or no possibility that the motive for the classification was illegitimate racial prejudice or stereotype.

395. Craig v. Boren, 429 U.S. 190, 198 (1976); see also id. at 199 ("In light of the weak congruence between gender and the characteristic or trait that gender purported to represent, it was necessary that the legislatures choose either to realign their substantive laws in a gender-neutral fashion, or to adopt procedures for identifying those instances where the sex-centered generalization actually comported with fact."). 
closely the state's means are related to its ends. ${ }^{396}$ Rather, one has to ask, in what ways might assumptions about the proper roles of men and women have moved the state to engage in fetal life-saving by compelling pregnancy? What view of women prompted the state's decision to use them as a means to an end? Given the constitutionally suspect means that laws restricting abortion employ to promote the state's interest in potential life, and especially given their history of overt gender-based justifications, it is patently unreasonable to assume $a$ priori that they are adopted by a process of legislative deliberation free from constitutionally illicit judgments about women.

As Part III of this article suggests, there is strong evidence that the attitudes which first prompted enactment of abortion-restrictive regulation still persist. ${ }^{397}$ Although the separate spheres tradition no longer receives official public sanction, the sex-role concepts it fostered continue to play a crucial part in the abortion controversy, supplying norms of sexual and maternal comportment for women that inform public judgments about the propriety of abortion. For example, in Louisiana, where the legislature recently attempted to enforce the state's nineteenth century criminal abortion statute and then enacted severe restrictions on abortion, ${ }^{398}$ a poll of the state's residents indicated they favored providing women access to abortion when pregnancy occurred because of incest or rape ( 89 percent); when the child is likely to have serious birth defects (67 percent); when childbirth might en-

396. Robin West has discussed this critical blind spot in the so-called "rationality" model of equal protection review. In analyzing the constitutionality of marital rape exemptions, she notes that equal protection doctrines focus on questions of legislative rationality in a manner that can completely obscure the gender-based judgments informing state action:

The damage occasioned by [marital rape exemptions] is the subordination . . . of the psychic, physical, emotional, and erotic female self. Under a rationality model this clear fact entirely escapes constitutional notice. ... If the state wants to pursue the goal of marital privacy, harmony, and spousal reconciliation at the cost of female self-sovereignty, and if the Court decides that the goal of marital privacy is important (which it surely could), then the marital rape exemption is an imminently rational, hence constitutional, way to achieve this goal .... The rationality model of equal protection quite dramatically fails to target the state's complicity in [subordinating women].

Robin West, Equality Theory, Marital Rape, and the Promise of the Fourteenth Amendment, 42 FLA. L. REV. 45, 69-70 (1990).

Equal protection doctrine treats a legislature's choice of race- or sex-based means as suspect, and then proceeds to determine how closely the state's means are related to its ends in order to "smoke out" constitutionally illicit judgments. In this framework, all sex-based means are suspect, but none need be examined with any particularity. From a socio-historical standpoint, however, some sex-based means are more suspect than others. Given their history, restrictions on abortion and marital rape exemptions are deeply suspect means no matter how benign a legislature's objectives may be.

In short, to determine whether constitutionally illicit judgments about women informed a state's decision to legislate by sex-based means, it is important to examine the particular sex-based means employed: It should matter whether the state is restricting men's access to $3.2 \%$ beer, see Craig v. Boren, 429 U.S. 190, 192 (1976), or subjecting women to forced childbearing or forced sex. If equal protection review is inattentive to these distinctions, then justice will indeed be blind.

397. See text accompanying notes 260-279 supra.

398. See Weeks v. Connick, 733 F. Supp. 1036 (E.D. La. 1990) (prohibiting state efforts to revive pre-Roe criminal abortion statutes); 1991 La. Sess. Law Serv. 74 (West) (prohibiting abortion unless undertaken for the express purpose of saving the life of the mother; allowing abortion where pregnancy has resulted from certain acts of rape or incest, but only under narrowly enumerated conditions). 
danger a woman's health ( 64 percent), or when childbirth might endanger a woman's mental health ( 64 percent); but 79 percent of respondents were opposed to abortion "when childbirth might interrupt the woman's career."399 The most widespread support for abortion depended upon a judgment about the sexual relations in which unborn life was conceived, and the most widespread opposition to abortion reflected a judgment about women's pursuit of career opportunities in conflict with the maternal role. National polls and sociological research confirm that such attitudes are widespread. ${ }^{400}$ In $A$ bortion and the Politics of Motherhood, Kristin Luker demonstrates how conflicts over abortion reflect divergent views about the proper role of sexuality, work, and family commitments in women's lives, contending that "[t]he abortion debate is so passionate and hard-fought because it is a referendum on the place and meaning of motherhood."401

Thus, today, as in the nineteenth century, legislators enacting restrictions on abortion may act from judgments about the sexual and maternal conduct of the women they are regulating, and not merely from a concern about the welfare of the unborn. Legislators may condemn abortion because they assume that any pregnant woman who does not wish to be pregnant has committed some sexual indiscretion properly punishable by compelling pregnancy itself. ${ }^{402}$ Popular support for excusing women who are victims of rape or incest from the proscriptions of criminal abortion laws demonstrates that attitudes about abortion do indeed rest on normative judgments about women's sexual conduct. Opinion polls like Louisiana's suggest that the public assumes a woman can be coerced into continuing a pregnancy because the pregnancy is her sexual "fault." 403

Along distinct, but related lines, legislators may view abortion as repellant because it betrays a lack of maternal solicitude in women, or otherwise violates expectations of appropriately nurturing female conduct. If legislators assume that women are "child-rearers," they will take for granted the

399. John Hill, New Poll: Abortion Veto OK, Gannett News Service, Sept. 7, 1990, available in LEXIS, Nexis Library, GNS File.

400. See notes 273-275 supra and accompanying text.

401. K. LUKER, supra note 65, at 193 (emphasis omitted).

402. See, e.g., Mary Kay Blakely, Remembering Jane, N.Y. Times, Sept. 23, 1990, (Magazine), at 26 (quoting an Indiana legislator who characterized women who seek abortions as "irresponsible women who get themselves pregnant," and observing that "[n]o one in the audience challenged his apparent belief in parthenogenesis, preferring to keep men's role in the abortion drama invisible"); cf. Michael M. v. Superior Court, 450 U.S. 464, 473 (1981) (plurality opinion) (discussing pregnancy as a form of punishment for young women who have sex, which imposes "natural sanctions" on them).

403. This view sometimes finds expression in the argument that in consenting to sex, a woman has either consented to the pregnancy that may result from it, or has at least voluntarily "assumed the risk" of conception; thus the community may justifiably force her to continue the pregnancy. This argument is riddled with so many difficulties that its persuasive force would seem in fact to depend on a priori assumptions about women's obligations as mothers.

First, the argument seems to assume that all sexual intercourse not legally cognizable as rape is consensual. The law of rape serves policy concerns not applicable in the abortion context (e.g., protecting the accused; "protecting" the marriage relation), and the concepts of consent it has developed are generally inadequate to detect sexual coercion between intimates. In an intimate relation, a woman may engage in sex under conditions of physical, emotional, or even economic duress which 
work women give to motherhood and ignore what it takes from them, and so will view women's efforts to avoid some two decades of life-consuming work as an act of casual expedience or unseemly egoism. Thus, they will condemn women for seeking abortion "on demand," or as a mere "convenience," judging women to be unnaturally egocentric because they do not give their lives over to the work of bearing and nurturing children-that is, because they fail to act like mothers, like normal women should. 404

While enforcing moral judgments resting on traditional sex-role assumptions about women may be the actual purpose of a legislature's decision to restrict abortion, ${ }^{405}$ it is crucial to recognize that a legislature need not attempt to enforce its views of appropriate sexual or maternal conduct in order for such attitudes to play an important role in the enactment of abortionrestrictive regulation. Even if state actors have adopted restrictions on abortion out of a genuine and single-minded concern for the welfare of the unborn, archaic or stereotypical assumptions about women may nonetheless deeply bias their deliberations, making fetal life-saving by compelled pregnancy seem reasonable where otherwise it would not. A legislature's attitudes about women may cause it to underestimate or disregard the burdens it would impose on them by compelling pregnancy. A latent assumption that motherhood is women's "normal" condition can easily render state actors oblivious to the life-consuming consequences of forcing women to perform its work-just as a latent assumption that motherhood is women's

will still appear consensual from the standpoint of the law. In short, consent and voluntariness in sexual intercourse demand distinctions of degree to which this argument is utterly inattentive.

Second, the consent-to-sex argument does not excuse those who conscientiously use contraceptive methods that nevertheless fail.

Third, the argument ignores the ways this society discourages women from taking the initiative in matters of contraception lest they look like they have taken the initiative in matters of sex.

Fourth, like the just-punishment argument, the consent-to-sex argument visits the consequences of sexual activity on the woman alone, ignoring the male partner who may have initiated or forced sex, and who may have failed to use contraception or actively discouraged its use. Thus, like the just-punishment argument, the consent-based argument rests on a sexual double standard, assuming that women must engage in sex for procreative purposes, but not men.

Fifth, the argument would impose some two decades of obligation on a woman for "choosing" to engage in a common social act that is not only condoned, but actively encouraged, by the society that would judge her. (Reasoning in analogous terms, one might argue that a woman raped outside her home assumed the risk of rape by voluntarily choosing to leave her home, or, as the AngloAmerican legal tradition has long argued, a woman who is raped in marriage "consented" to sex because she voluntarily chose to marry, see note 362 supra).

At root, the argument assumes the very duty it purports to justify. Consent-based justifications for compelling a pregnant woman to bear a child acquire their persuasive force from a latent assumption that the pregnant woman ought to bear the child, which appears as an obligation individually assumed by her so long as some voluntary act can be found to support it. Consent-based arguments of this sort have long been employed to enforce relations of gender status. See note 362 supra.

404. Objections to abortion "on demand" or "for convenience" can be traced directly to the nineteenth century campaign, where they played a role in arguments that explicitly invoked women's maternal duties. For a comparison of contemporary and nineteenth century rhetoric, see note 276 supra. For an account of the reasons women actually give for having abortions, and the frequency with which they actually have abortions, see note 457 infra.

405. Cf. note 376 supra (noting that court may inquire whether nominally benign purpose of legislation is its actual purpose in fact). 
"deserved" condition will cause indifference to the burdens the legislation will inflict. In short, a legislature may not decide that it is reasonable to save unborn life by compelling pregnancy, "but for" the archaic or stereotypic assumptions about women it holds. If restrictions on abortion are adopted in these circumstances, they offend constitutional guarantees of equal protection. 406

\section{Evidence of gender bias in abortion-restrictive regulation.}

Evidence that a state's decision to enact abortion-restrictive regulation was rooted in judgments about women's appropriate sexual or maternal conduct may be found in the record of legislative debate. But as Part III of this article suggests, there are other ways of determining whether abortion-restrictive regulation rests on constitutionally offensive assumptions about women. Analyzing the terms of the statute, or situating it in larger policy context, can yield structural evidence of such assumptions-if one asks, how consistently does the state act to protect the unborn? In what circumstances does the state act or refrain from acting, and why? In doctrinal parlance, are the means a state has chosen to promote the welfare of unborn life underinclusive with respect to its ends? ${ }^{407}$

As we have seen, the selective focus of fetal-protection policies can supply evidence that such regulation rests on social assumptions about women's roles. Regulatory selectivity prompted the Supreme Court's observation that the "[ $t]$ he bias in Johnson Controls' policy is obvious. Fertile men, but

406. See text accompanying notes $375-381$ supra. Under prevailing equal protection doctrine, sex-based state action is subject to heightened scrutiny, an inquiry that examines the legislature's means and ends to determine whether the legislative process has been infected by stereotypical sexrole assumptions or other constitutionally impermissible forms of gender bias-but need not ascertain the existence of discriminatory purpose, the ultimate fact to be proved where the action challenged is facially neutral. Compare Mississippi Univ. for Women v. Hogan, 458 U.S. 718, 723-27 (1982) and Craig v. Boren, 429 U.S. 190, $197-99$ (1976) (sex-based legislation) with Personnel Adm'r of Mass. v. Feeney, 442 U.S. 256, 273-74 (1979) and Washington v. Davis, 426 U.S. 229, 238-48 (1970) (facially neutral legislation). In many, if not most, of the cases where the Court has invalidated sex-based legislation under the Equal Protection Clause, the legislation was enacted for benign purposes. See, e.g., Craig, 429 U.S. at 199-200 (invalidating liquor sales statute adopted to promote traffic safety).

Even when the Court has reviewed challenges to regulation that does not explicitly discriminate on the basis of some characteristic or trait of a protected class, it has still allowed plaintiffs to prove discrimination by demonstrating that the challenged regulation was the product of "mixed motives." See, e.g., Hunter v. Underwood, 471 U.S. 222, 228 (1985) ("Once racial discrimination is shown to have been a 'substantial' or a 'motivating' factor behind the enactment of the law, the burden shifts to the law's defenders to demonstrate that the law would have been enacted without this factor.") (citing Mt. Healthy City Bd. of Educ. v. Doyle, 429 U.S. 274, 287 (1977)); cf. Price Waterhouse v. Hopkins, 490 U.S. 228 (1989) (analyzing the role of stereotypical attitudes about women in causing employment discrimination against them; applying Mt. Healthy "mixed motive" analysis).

407. While "[i]t is no requirement of equal protection that all evils of the same genus be eradicated or none at all," Railway Express Agency v. New York, 336 U.S. 106, 110 (1949), when the Court reviews legislation embodying constitutionally suspect classifications, it will examine whether a legislature's means are underinclusive with respect to its ends as a method of "smoking out" constitutionally impermissible bias. See note 394 supra and accompanying text; see also Loving v. Virginia, 388 U.S. 1, 11 (1967) ("The fact that Virginia prohibits only interracial marriages involving white persons demonstrates that the racial classifications [are] measures designed to maintain White Supremacy."). 
not fertile women, are given a choice as to whether they wish to risk their reproductive health for a particular job."408 For similar reasons, analyzing the pattern of exceptions or excusing conditions stipulated in abortion-restrictive regulation can supply evidence that the state's willingness to save unborn life rests on unarticulated assumptions about the women whose conduct it would regulate.

For example, the criminal abortion statute that Utah recently enacted provides exceptions when "abortion is necessary to save the pregnant woman's life" or "to prevent grave damage to the pregnant woman's medical health"; in certain cases "when pregnancy is the result of rape" or "the result of incest"; and "to prevent the birth of a child that would be born with grave defects." 409 The state does not consistently act to protect unborn life. Rather, as the statute's preamble explains, the state has determined that "a woman's liberty interest, in limited circumstances, may outweigh the unborn child's right to protection." 410 Thus, the state is indeed making judgments about women as well as the unborn.

The statutory exception allowing women to have abortions if they conceive by an act of rape or incest indicates that the state's decision to compel women to bear children depends upon certain normative judgments about women's sexual conduct. ${ }^{411}$ The apparently widespread belief that it is reasonable to force women who have consented to sex to bear children likely rests on unarticulated social assumptions about women's maternal obligations. ${ }^{412}$ But, more importantly, rape exceptions of this sort offend core values of equal protection because they rest on a sexual "double-standard." Utah has decided to punish pregnant women who have "voluntarily" engaged in sex by making them bear children, yet it has enacted a statute that imposes no similar duties, burdens, or sanctions on the men who were coparticipants in the act of conception. 413

Traditional sex-role assumptions also shape the exception that allows

408. UAW v. Johnson Controls, Inc., 111 S. Ct. 1196, 1202 (1991). For other examples of selectivity in fetal-protection policies, see text accompanying notes 332-341 supra.

409. UTAH CODE ANN. \& 76-7-301, -302 (1991).

410. Id. § 76-7-301.1.

411. In fact, a sentence struck from the preamble to the Utah statute read: "It is recognized that, in cases of rape or incest, the fact that the woman has been an unwilling participant in the reproductive process may justify the preference for her rights over those of the unborn child." Id. (Amendment Notes).

412. See note 403 supra and accompanying text.

413. It does not cure this objection to observe that men are subject to general child support obligations-the enforcement of which is notoriously lax. Both parents are under such a duty. Meanwhile, the state subjects men to no burden even remotely approaching that of coerced childbearing. If the state decides to make a pregnant woman bear a child because she has chosen to have sex, no fact of nature prevents the state from imposing duties or sanctions on the man who was co-participant in the act of conception. Cf. Jeff Rosen, Naturally Right, NEw REPUBLIC, Sept. 24, 1990, at 20, 23 (quoting Professor Akhil Amar, who discusses the sexual inequality of abortion restrictions, noting " $[t]$ he law does not require men ... to support the women they have impregnated during the course of an unwanted pregnancy").

By imposing unilateral duties on women for engaging in consensual sex, the state has defined the proper ends of female sexuality as procreative, and punished women who violate this norm by forcing them to bear children. The rape exemption thus holds women to standards of sexual conduct 
abortions to save the pregnant woman's life or to prevent grave damage to her health. The therapeutic exception indicates that the state is willing to subordinate the welfare of the unborn to that of the pregnant woman, but only when women will sustain physical injuries in bearing children. Indeed, more than any sex-based legislation the Court has reviewed in the modern era, the therapeutic exception graphically defines women as childbearers. Utah has weighed "woman's liberty interest" against that of the unborn, and decided that women can be forced to be mothers except when they are physically incapable of the act. By allowing women abortions, but only when pregnancy threatens to kill them or to inflict "grave damage" on their "medical health," Utah has defined the pregnant woman's "liberty interest" as an interest in brute physical survival-reasoning about women as if they had no social, intellectual, or emotional identity that transcended their physiological capacity to bear children. ${ }^{414}$ Thus, analyzing the excusing conditions in Utah's statute, it appears that the state has promulgated a code of conduct for pregnant women that distinguishes "good" abortions from "bad" abortions-whose very reasonableness depends on unarticulated sex-role assumptions about women. ${ }^{415}$

Analyzing abortion-restrictive regulation in larger policy context may also reveal that the state manifests its concern for the unborn in underinclusive or selective ways that suggest latent sex-role assumptions about women. A legislature may express interest in the welfare of the unborn forcefully in circumstances that involve compelling women resisting motherhood to perform its work, but intermittently, ambivalently, or not at all, in policy contexts that involve supporting women seeking to become mothers in their

and maternal duty whose roots lie deep in the nineteenth century. $C f$. text accompanying notes 116134 supra.

414. In the years before Roe was decided, a critic of expansive therapeutic exceptions openly articulated the view of women that is implicit in Utah's "balancing" of maternal and fetal interests:

A mother who would sacrifice the life of her unborn child for her own health is lacking in something. If there could be any authority to destroy an innocent life for social considerations, it would still be in the interests of society to sacrifice such a mother rather than the child who might otherwise prove to be normal and decent and an asset.

Quay, supra note 85, at 234.

The therapeutic exception does not merely define women as childbearers. Because this exception to criminal abortion statutes removes decisions about a pregnant woman's welfare and needs from the pregnant woman to her medical guardian, it is as paternalist today as it was in the nineteenth century. Cf. H.R. STORER, supra note 123, at 115-16:

Every married woman, save in very exceptional circumstances, which should only be allowed to be such by the decision of a competent physician, every married woman, until near the so-called turn of life, should occasionally bear a child; not as a duty to the community merely . . . but as the best means of insuring her own permanent good health.

See also H. STORER \& F.F. HEARD, supra note 95 , at 4 ("medical men are the physical guardians of women and their offspring; from their position and peculiar knowledge necessitated in all obstetric matters to regulate public sentiment, and to govern the tribunals of justice"); text accompanying notes $130-133$ supra.

415. Cf. Frank Zimring, Constitutional Doctrine in Societal Context: Revisiting Roe v. Wade, at 15-16 (n.d.) (unpublished manuscript on file with the Stanford Law Review) ("[T]he aim and method of the American Law Institute-Model Penal Code statute is not determining the value of fetal life but the separation of deserving from undeserving women."). 
desire to bear and rear healthy children. ${ }^{416}$ Here the state's choice of sexbased, coercive means suggests that it is interested in controlling and/or punishing women who resist motherhood: It will promote the welfare of the unborn only when it can use women's bodies and lives to realize the potential of unborn life-and not when the community as a whole would have to bear the costs of its moral preferences.

Finally, as analysis of the fetal-protection policy in Johnson Controls clearly illustrates, regulators may adopt particular means for protecting unborn life because stereotypical assumptions about the maternal role lead them to underestimate the impact of fetal-protective regulation on women. If one examines the conventional structure of abortion-restrictive regulation, it does indeed appear that such regulation must rest on traditional assumptions about women's natural obligations or instrumental uses as mothers. Absent such attitudes about women, it is reasonable to assume that legislatures would adopt at least some measures to offset the consequences of compelled motherhood for women, whether by compensating them, or by protecting their employment and education opportunities, or by affording them needed medical services and child care. Normally, some remuneration, reward, support, and/or recognition is offered to those asked to perform services for the community, whether they are asked to provide foster care for children, volunteer or are drafted for military service, or are compelled to alienate property to the state. If no offsetting or compensating measures are adopted or even contemplated when the state engages in fetal life-saving by compelled pregnancy, it is clear that abortion-restrictive regulation is indeed premised on certain views about women as well as the unborn: that women's physical and intellectual and emotional energies as mothers can be publicly appropriated without recompense, that their lives can be subordinated to the work of gestation and nurturance without consequence.

Because the state has chosen to promote the welfare of the unborn by sex-based, coercive means, it carries the burden of demonstrating that the statute does not rest on constitutionally offensive assumptions about women. ${ }^{417}$ A state seeking to demonstrate that its decision to compel pregnancy was moved by concern for the unborn, and not traditional sex-role assumptions about women, could carry this burden by supplying evidence of the following sort: by showing that the state does all in its power to promote the welfare of unborn life by noncoercive means, supporting those women who do wish to become mothers so that they are able to bear and raise healthy children; by demonstrating that the sacrifices the state exacts of women on behalf of the unborn are in fact commensurate with those it exacts of men-and the community in general-to promote the welfare of fu-

416. Cf. text accompanying notes 342-346 supra.

417. Mississippi Univ. for Women v. Hogan, 458 U.S. 718, 724 (1982) ("party seeking to uphold a statute that classifies individuals on the basis of their gender must carry the burden of showing an 'exceedingly persuasive justification' for the classification") (quoting Kirchberg v. Feenstra, 450 U.S. 455,461 (1981)). 
ture generations; 418 and, even, by showing that the state is ready to compensate women for the impositions and opportunity costs of bearing a child they do not wish to raise. A state that could demonstrate such a consistent course of conduct could indeed claim that it was an accident of nature that the state had to make the pregnant woman a samaritan for the unborn, and that its decision to do so had no roots in assumptions about her natural obligations or instrumental uses as a mother. I know of no jurisdiction in this nation that can pass the test. ${ }^{419}$

To this point, I have analyzed abortion-restrictive regulation from the standpoint of antidiscrimination values to demonstrate that a legislature's decision to adopt such regulation may indeed reflect attitudes toward women that are offensive to principles of equal protection. This analysis provides a basis for questioning the legitimacy of a state's purposes in compelling pregnant women to bear children. And, even if one follows Roe in defining fetal life-saving as the purpose of legislative restrictions on abortion, the analysis still supplies a framework for scrutinizing the state's decision to promote the welfare of unborn life by coercive, sex-based means. But for certain stereotypical assumptions about women, a legislature may not view coercing women to perform the work of motherhood as a reasonable way of promoting the welfare of the unborn. But for certain stereotypical assumptions about women, a legislature might act to mitigate or offset the burdens it imposes on women by compelling them to bear children. If a legislature would not in fact employ the means it has chosen to promote the welfare of the unborn but for "the traditional ... assumptions about the proper roles of men and women" it holds, its benign objectives cannot save abortion-restric-

418. This showing is especially required if the state has conditioned the pregnant woman's obligation to bear children on her sexual conduct (e.g., by incorporating a rape exemption in the statute). See note 413 supra and accompanying text.

419. For some evidence of this nation's failure to support women who desire to become mothers and its failure to promote the welfare of future generations by means that support, rather than coerce, women, consider:

(1) President Bush's decision to veto the Family and Medical Leave Act, which would provide job security for pregnant women and parents who need leave from work for purposes of family caregiving, see Sharon A. Holmes, Bush Vetoes a Bill to Give Workers Family Leave, N.Y. TiMES, June 30, 1990 at A9; see also Tamar Lewin, Battle for Family Leave Will Be Fought in States, N.Y. TIMES, July 27, 1990, at A8 ("Mr. Bush said he thought the measure would have been an unwarranted intrusion of government into business affairs.");

(2) our failure to provide prenatal care to pregnant women who lack health insurance, see note 344 supra, as well recent attempts to reduce funding to programs providing nutritional supplements to pregnant women, infants, and children, despite this nation's startlingly high infant mortality rates, see Pear, supra note 342, at A10 (each year in U.S., nearly 40,000 babies die before reaching their first birthday, a fact described by the Secretary of Health and Human Services as "almost obscene for a country with the resources we have"); Robert Pear, Bush Plan to Fight Infant Deaths Would Use Money Going to Poor, N.Y. TIMES, Feb. 7, 1991, at Al (administration proposes plan to combat " 'exceptionally high rates of infant mortality" in ten cities "by taking money from other health programs that serve pregnant women, poor children and the homeless"). But see Robert Pear, Food Assistance to Poor Women Gets a Reprieve, N.Y. TIMES, June 30, 1990, at A1 (Congress authorizes bill allowing states to borrow against next year's allocation, in order to minimize cutbacks in program);

(3) the fact that more than half of the children living in female-headed households are impoverished, see notes $455-456$ infra. 
tive regulation from constitutional indictment. 420

Yet for many, this approach to analyzing abortion-restrictive regulation may be plagued by two kinds of uncertainty: uncertainty about the nature of the legislative judgments on which the regulation actually rests, and, perhaps even more importantly, uncertainty about the moral gravity of the gendered judgments that can in fact be seen to animate it. These uncertainties seem inherent in the analytical orientation of equal protection doctrine, which is organized to detect breaches of the antidiscrimination principle, and therefore demands judgments about the reasoning of state actors rather than the character of their conduct. If the only objective in analyzing a legislature's conduct is to elicit evidence of its collective "state of mind," then the doctrines of heightened scrutiny will obscure the most important sense in which restrictions on abortion offend equal protection commitments: one defined in terms of the harm abortion-restrictive regulation inflicts on women rather than the judgments about them it reflects. To rectify this problem, it is necessary to examine abortion-restrictive regulation from an antisubordination perspective. As I see it, this approach can either supplement analysis from an antidiscrimination perspective, ${ }^{421}$ or provide an alternative framework for review.

\section{The Antisubordination Inquiry}

When the Court declared in Brown v. Board of Education ${ }^{422}$ that de jure segregation violated constitutional guarantees of equal protection, it did not confine its analysis to the attitudes and judgments of the state actors responsible for the policy. The Court emphasized the injury segregation inflicted on the schoolchildren subjected to it. ${ }^{423}$ It judged the constitutionality of de jure segregation by the specific forms of status harm it imposed, not simply the regulatory distinctions it embodied. ${ }^{424}$ Today, equal protection doctrine is largely elaborated from an antidiscrimination perspective, whose dominant focus is the judgment and justifications of the state actors deploying public power, rather than the impact of a particular exercise of power on the

420. See note 406 supra and accompanying text.

421. Obviously, one is more concerned about the nature of the state's justifications for adopting restrictions on abortion when one considers the character and magnitude of the injury such regulation inflicts on women. In addition, considering the harm abortion-restrictive regulation inflicts on women imbues the task of determining whether sex-dependent judgments might have prompted the state to enact it with greater urgency. Finally and more generally, the moral gravity of entertaining "traditional assumptions about the proper roles of men and women" is easier to grasp once one considers the harm that laws premised on such assumptions can inflict on women.

422. 347 U.S. 483 (1954).

423. See id. at 494 ("To separate [black children in public schools] from others of similar age and qualifications solely because of their race generates a feeling of inferiority as to their status in the community that may affect their hearts and minds in a way unlikely ever to be undone.").

424. See Randall Kennedy, Persuasion and Distrust: $A$ Comment on the Affirmative Action Debate, 99 HARV. L. REV. 1327, 1336 (1986) ("Brown and its progeny do not stand for the abstract principle that governmental distinctions based on race are unconstitutional. Rather, [they] ... stand for the proposition that the Constitution prohibits any arrangements imposing racial subjugation ....."); see also Laurence $\mathrm{H}$. Tribe, "In What Vision of the Constitution Must the Law Be ColorBlind?," 20 J. MARShall L. ReV. 201, 204-05 (1986). 
citizens subject to it. ${ }^{425} \mathrm{~A}$ growing number of constitutional commentators would reorient the focus of equal protection analysis so that it directly considered the impact of state action on the citizens affected by it, a paradigm shift of consequence to numerous areas of constitutional debate. ${ }^{426}$ Sylvia Law has employed antisubordination values to develop a framework for evaluating state regulation of reproduction, which she applies to analyze the constitutional equities of abortion-restrictive regulation itself. 427

While there are many principles one could employ to craft an equal protection standard for evaluating the subordinating effects of state actionwhich might embrace overtly discriminatory and facially neutral policies, as well as the harms they foreseeably and inadvertently cause-undertaking this far-reaching enterprise is not necessary to evaluate abortion-restrictive regulation. Abortion-restrictive regulation has several characteristics that make it particularly suitable for analysis under even the most constrained application of antisubordination principles. ${ }^{428}$ First, abortion-restrictive

425. The clearest illustration of this orientation is the requirement that plaintiffs challenging the discriminatory impact of facially neutral state action must show that state actors adopted the challenged policy with discriminatory purpose. See Personnel Adm'r of Mass. v. Feeney, 442 U.S. 256, 274, 279 (1979). Doctrines governing the review of explicitly race- and sex-based state action are informed by this antidiscrimination perspective in less apparent ways. The fact that such action triggers heightened scrutiny refiects concern that the state will inflict or perpetuate forms of status injury by legislating in race- and sex-based terms. See note 369 supra. Yet, doctrinal standards for determining the constitutionality of such action scrutinize the character of a legislature's judgments, without directly putting in issue the actual impact of its actions on members of protected classes. The results in many of the Court's gender discrimination cases might well be different if the Court inquired, not whether the state's decision to regulate on the basis of sex was substantially related to important governmental ends, but instead: Has the challenged action harmed women in ways that enforce, perpetuate, or aggravate their subordinate social status?

426. Commentators have employed antisubordination values to distinguish between benign and invidious race- and sex-based state action, as well as to criticize doctrines requiring a showing of discriminatory purpose to challenge facially neutral state action. See, e.g., C. MAcKInNon, supra note 5, at 32-45; Catharine A. MacKinNon, Sexual Harassment of Working Women 117 (1979) (arguing that courts examining state action for sex discrimination should inquire "whether the policy or practice in question integrally contributes to the maintenance of an underclass or a deprived position because of gender status"); L. TRIBE, supra note 5, § 16-21, at 1514-21; Owen M. Fiss, Groups and the Equal Protection Clause, 5 PHIL. \& PUB. AFF. 107, 157 (1976) (proposing to substitute for the equal treatment principle a group-disadvantaging principle premised on a theory of "status harm" that would inquire whether a challenged practice would "impair or threaten or aggravate the status or position of the group"); Kennedy, supra note 424, at 1334-37; Charles R. Lawrence III, The Id, the Ego, and Equal Protection: Reckoning with Unconscious Racism, 39 STAN. L. REv. 317, 319 (1987) ("the injury of racial inequality exists irrespective of the decisionmakers' motives"); West, supra note 396, at 59-62 (discussing work of Catharine MacKinnon, Ruth Colker, and Mary Becker).

427. See Law, supra note 5, at 1008-09 ("[L]aws governing reproductive biology should be scrutinized by courts to ensure that (1) the law has no significant impact in perpetuating either the oppression of women or culturally imposed sex-role constraints on individual freedom or (2) if the law has this impact, it is justified as the best means of serving a compelling state purpose."); see id. at 1016-28 (analyzing abortion regulation under this test).

428. Antisubordination analysis need not assume the form of a simple disparate impact test of the sort the Court has adopted in the employment discrimination context, but refused to extend to a constitutional setting. See Washington v. Davis, 426 U.S. 229, 248 (1976) (applying a disparate impact analysis to facially neutral state action "would ... perhaps invalidate, a whole range of tax, welfare, public service, regulatory, and licensing statutes that may be more burdensome to the poor and average black than the more affuent white"); $c f$. L. TRIBE, supra note 5, $\S 16-21$, at 1520:

[S]trict judicial scrutiny would be reserved for those governmental acts that, given their 
regulation is sex-based state action:429 It is regulation directed at women as a class, and not dispersed across the citizenry at large. Second, the most dramatic and visible of its effects-the continuation of an unwanted pregnancy-is an intended consequence of social policy. Indeed, as I have already argued, it is fair to characterize forced childbearing as the principal purpose of abortion-restrictive regulation. ${ }^{430}$ Third, abortion-restrictive regulation has historically functioned as caste legislation. Finally, today, as in the past, the injury inflicted on women by compelling them to bear children is a specific form of status harm, one that plays a central role in women's subordination.

These factors together provide for a highly focused application of antisubordination principles. Because a state adopting restrictions on abortion intentionally inflicts a traditional form of status harm on a constitutionally suspect class, courts evaluating the constitutionality of the state's action should examine what the state is doing to women, and not simply why it does it. Examining how restrictions on abortion harm women supplies an independent and sufficient basis for evaluating the constitutionality of abortion-restrictive regulation. It also supplies evidence relevant to more conventional forms of equal protection analysis: If one wants to determine whether a state's decision to adopt abortion-restrictive regulation rests on constitutionally offensive sex-role assumptions about women, it is crucial to examine what a state adopting restrictions on abortion does to women.

This section considers how state action restricting abortion injures women, addressing several points which bear on this question. First, restrictions on abortion do not merely force women to bear children; powerful gender norms in this society ensure that almost all women who are forced to bear children will raise them as well, a result that legislatures adopting restrictions on abortion both desire and expect. Second, the work legislatures would force women to perform defines women's social status along predictable, gender-delineated lines. Women who perform the socially essential labor of bearing and rearing children face diverse forms of stigmatization and injury, none of which is ordained by the physiology of gestation, and all of which is the doing of the society that would force women to bear children. Third, when states adopt restrictions on abortion, they compel women to become mothers, while in no respect altering the conditions that make the institution of motherhood a principal cause of women's subordinate social status. When the gender-based impositions of abortion-restrictive regulation are considered in light of the forms of gender bias that may animate it, it is clear abortion-restrictive regulation is and remains caste legislation which subordinates women in ways that offend constitutional guarantees of equal protection.

history, context, source, and effect, seem most likely not only to perpetuate subordination but also to reflect a tradition of hostility toward an historically subjugated group, or a pattern of blindness or indifference to the interests of that group.

429. See note 373 supra and accompanying text.

430. See text accompanying note 387 supra. 


\section{Abortion restrictions coerce childbearing and childrearing.}

Laws that forbid or impair women's access to abortion ${ }^{431}$ in fact have many effects on women's lives. Restrictions on abortion affect not only pregnant women, but all women who believe they are capable of conceiving, whether or not they are presently sexually active, whether or not they engage in some form of contraceptive practice. Because such laws deprive women of means to determine whether or not they will become mothers should they become pregnant, they impair the possibility of sexual pleasure for women, and aggravate the force of sexual fear. ${ }^{432}$ Abortion-restrictive regulation does not of course prevent all pregnant women who seek abortions from obtaining them; rather, it subjects all pregnant women seeking abortions to social indignity, some to illicit procedures fraught with fear and physical hazard, and the rest to the burden of state-coerced pregnancy.

Laws restricting women's access to abortion are only intermittently discussed in their compulsive aspect. Even then, discussion often seems to assume that such regulation coerces women into performing only the work of childbearing. ${ }^{433}$ But if abortion-restrictive regulation is evaluated in light of actual social practice, it is clear that such regulation coerces women to perform, not only the work of childbearing, but the work of childrearing as well.

Hypothetically, a woman compelled to bear a child she does not want could give it up for adoption, abandon it, or pay someone to care for the child until maturity. In this society, however, these are not options that women avail themselves of with great frequency for the simple reason that few women are able to abandon a child born of their body. ${ }^{434}$ That society as a whole, or some women in particular, may judge it morally preferable to give a child up to adoption rather than abort a pregnancy is beside the point. Once compelled to bear a child against their wishes, most women will feel

431. Here I address laws that prohibit or restrict the performance of abortion in ways that signify social condemnation of the practice, including laws that attempt to deter women from obtaining abortions by interposing procedural obstacles, financial barriers, or other practical impediments to access to the procedure. Depending on a woman's age, financial means, family situation, and sophistication, she may or may not be deterred by them. Some women will be able to evade laws prohibiting abortions; others will be prevented from obtaining abortions by laws that merely interpose practical impediments to abortion.

432. Cf. G. Calabresi, supra note 5; C. MacKinnon, supra note 5, at 93-102; Law, supra note 5, at 1019-20.

433. See Regan, supra note 5, at 1589-91; but cf. Koppelman, supra note 5, at $490 \mathrm{n} .45$ (citing Rubenfeld, supra note 5, at 790 n.204).

434. Of all babies placed for adoption in $1982,88 \%$ were born to mothers who had never married, $6 \%$ were born to mothers who had been married but were unmarried at the time of the birth, and $6 \%$ were bom within a marriage. It is important to note, however, that while premarital births account for the preponderance of adoption placements, only $6 \%$ of all babies born premaritally to women 15 to 44 years of age in 1982 were placed for adoption. White unmarried mothers were much more likely to place their children for adoption than black unmarried mothers; unmarried mothers whose fathers had some college education were much more likely to place their children for adoption than unmarried mothers whose fathers had not completed high school. Christine A. Bachrach, Adoption Plans, Adopted Children, and Adoptive Mothers, 48 J. Marriage \& FAM. 243, 249-50 (1986). 
obligated to raise it. ${ }^{435}$ A woman is likely to form emotional bonds with a child during pregnancy; she is likely to believe that she has moral obligations to a born child that are far greater than any she might have to an embryo/ fetus; and she is likely to experience intense familial and social pressure to raise a child she has borne. The pressure on women to raise children they have borne will intensify dramatically if they are married and/or have other children, as current adoption placements illustrate. 436 Women will also experience particularly intense pressure to raise a child if the child lacks the privileged characteristics that ensure it will be readily adopted. ${ }^{437}$

Thus, while discussions of abortion-restrictive regulation often assume that women who are forced to bear children can simply abandon them at will, the premise is wholly at odds with the norms of the society that would compel women to bear children. Many women will simply assume they must raise children which the state forces them to bear; others may well choose to raise the child, but they will exercise this choice under social conditions that virtually dictate the outcome of their decision. Legislatures that enact restrictions on abortion understand this. They both desire and expect that most women will raise the child they are forced to bear, and in the vast majority of cases, women will.

Of course, a state can deny responsibility for imposing motherhood on women simply by emphasizing that the pregnant woman has chosen to raise the child that the state forced her to bear. Arguments about women's choices offer a familiar way to rationalize state action enforcing gender status roles. ${ }^{438}$ But, if one considers the powerful norms governing women's choices about whether to raise their children, it is clear that such formalistic arguments do not relieve the state of responsibility for dictating the pregnant woman's social fate. In twentieth century America, when a legislature restricts women's access to abortion, it is forcing women to bear and rear children.

\section{The work of bearing and rearing children.}

What then does the state do to women by forcing them to bear children? To answer this question, it is necessary to consider what is entailed for

435. The Los Angeles Times reported that when women, who had undergone abortions were asked "whether it would be harder for an unmarried woman to rear a child out of wedlock, or give up the baby for adoption, or have an abortion, a majority (52\%) said the hardest thing would be to hand over the infant to adoption. The easiest was abortion (18\%)." George Skelton, Guilt Plagues Many Who Had Abortion, L.A. Times, Mar. 19, 1989, at 15 (emphasis added). It is important to note that the question posed concerns the case of an unmarried woman. If a woman had other children and/or was married, it seems quite likely that giving the child up for adoption would appear even more difficult.

436. See note 434 supra ( $88 \%$ of babies placed for adoption in 1982 were born to never-married mothers, while only $6 \%$ were born to women in an intact marriage); cf. note 457 infra (unmarried cohabiting women nine times as likely to have an abortion as married women living with their husband).

437. Cf. note 434 supra (white unmarried mothers much more likely to place their children for adoption than black unmarried mothers).

438. Cf. note 362 supra. 
women in performing the work of motherhood. While the burdens of motherhood are to a significant extent a matter of common knowledge, it is nonetheless important to consider certain aspects of the work that are regularly omitted from discussions of abortion. Too often, analysis of abortion-restrictive regulation is dominated by physiological paradigms, with the result that the injuries such regulation inflicts tend to be attributed to and described in terms of the female body. ${ }^{439}$ If the decision whether to terminate a pregnancy has special significance in women's lives, it is in part, but only in part, because of the physiology of reproduction. From the point of gestation onwards, a woman performing the work of parenting assumes the social role of motherhood, a role and status that defines her identity, relations, and life prospects in diverse social arenas.

For women, the work of parenting begins in a lengthy period of bodily labor. Because the work of making life does proceed within a woman's body, it can subject her to physical discomfort, pain, disability, and risk throughout the term of pregnancy, and after. These physical burdens alone are sufficient grounds for many to hesitate before assuming the work. 440 Yet, because gestation is not simply a reflex process, its impositions are not solely physiological. Childbearing, like childrearing, involves work to be performed in accordance with detailed prescriptive norms. ${ }^{441}$ A woman who attempts to conduct her pregnancy in conformity with such norms will find herself making daily judgments as she attempts to accommodate her life to the process of making life: choices about what to eat and drink, about how to exercise, about securing appropriate medical care, and about negotiating quotidian forms of risk associated with travel, leisure activities, and the work she performs on the job and at home. ${ }^{442}$ The work of gestation thus

439. Cf. Law, supra note 5, at 1016 ("When the state denies women access to abortion, both nature and the state impose upon women burdens of unwanted pregnancy that men do not bear."); id. at 1017 ("When the state prohibits abortion, all women of childbearing age know that pregnancy may violently alter their lives at any time. This pervasively affects the ability of women to plan their lives, to sustain relationships with other people, and to contribute through wage work and public life."); Regan, supra note 5, at 1579-82 (consulting obstetrical authorities to determine the impact of pregnancy on women's lives); see also Roe v. Wade, 410 U.S. 113, 153 (1973) (pregnancy has diverse health effects on women's lives; "maternity ... may force on the woman a distressful life and future"). But cf. MacKinnon, supra note 5, at 1308-09 ("women, because of their sex, are subjected to social inequality at each step in the process of procreation").

440. Donald Regan has collected a detailed list of "what two obstetricians, writing for pregnant women and attempting not to alarm but to reassure them, call the 'minor complaints' of pregnancy." Regan, supra note 5, 1579 (footnote omitted); see id. at 1582 ("It may seem that I must have got it wrong-that if having a child were as bad as I suggest, no woman would ever do it voluntarily."); see also Law, supra note 5, at $1017 \mathrm{n} .220$ (comparing health risks of childbirth and first trimester abortion).

441. In the nineteenth century, physicians advanced a theory of "prenatal impressions," which required a pregnant woman to avoid all shocking sights, intellectual stimulation, or powerful emotions, such as anger or lust, lest the baby be deformed in the womb. As they understood it, during pregnancy the brain and uterus competed for phosphates, such that every mental effort of the mother could deprive her unborn of substances required for proper development. See B. EHRENREICH \& D. ENGLISH, supra note 78, at 111, 127; see also C. DEGLER, supra note 74, at 79-82 (gestation and breast-feeding); C. ROSENBERG, supra note 67, at 26-29, 58, 68 .

442. Today, as in the nineteenth century, the pregnant woman is advised to conduct the work of gestation with attention to a complex set of factors that may affect the development of the unborn 
involves on-going calculations and compromises that can have a pervasive impact on women's lives; its impositions are simultaneously physical and social.

Because gestation is a social as well as a physiological act, it implicates women in relationships and defines their identity in many ways. A woman may experience pregnancy as a bond tying her to a man with whom she may or may not wish to be involved, or, alternately, it may signify the brute fact of his absence or abandonment. ${ }^{443}$ During the course of gestation, a pregnant woman often bonds to the unborn life she bears, so that over time a maternal relation is formed that she may feel herself incapable of severing. Nor is this relational aspect of pregnancy a matter of intimate experience alone. A woman may find that pregnancy comes to embody her social identity to others, who may treat her with love and respect or, alternatively, abuse her as a burden, ${ }^{444}$ scorn her as unwed, ${ }^{445}$ or judge her as unfit for employment. 446 Or, precisely because the work of pregnancy is believed to

in utero. Common conditions and activities of the pregnant woman that are currently believed to have some bearing on fetal development include: "being overweight or underweight, vorking or even living in certain environments, rejecting or undergoing specific medical treatments, exercising, failing to eat 'well,' failing to 'stay off of her feet,' smoking, drinking alcohol, ingesting caffeine, taking nonprescription, prescription, or illegal drugs, and suffering physical harm through accident or illness." Johnsen, From Driving to Drugs, supra note 6, at 192 . Conducting a pregnancy with attention to such concerns produces a daily regimen of calculations and compromises, not unlike that urged upon pregnant women a century ago. See C. RosENBERG, supra note 67, at 58 (discussing nineteenth century medical advice) (" $A$ woman who lived 'unphysiologically'-and she could do so by reading or studying in excess, by wearing improper clothing, by long hours of factory work, or by a sedentary, luxurious life-could produce only weak and degenerate offspring.").

443. On the relational aspects of pregnancy, see, e.g., C. GilligAN, supra note 276, at 71-74 (discussing abortion decision); NATIONAL ABORTION RIGHTS Action LEAGue, The Voices OF WOMEN (n.d.) (same); Brief for the Amici Curiae Women Who Have had Abortions and Friends of Amici Curiae in Support of Appellees, Webster v. Reproductive Health Servs., 492 U.S. 490 (1989) (No. 88-605) (same); see also Brief For the National Coalition Against Domestic Violence As Amicus Curiae Supporting Appellees, supra note 5, at 293 ("A battered woman who becomes pregnant is less able, economically and otherwise, to leave the batterer, and her economic dependence on the batterer will only increase if she is forced to bear the child.").

444. Evidence concerning the battering of pregnant women was introduced in the Court's most recent teen pregnancy cases. See Ohio v. Akron Ctr. for Reprod. Health, 110 S. Ct. 2972, 2991 (1990) (Blackmun, J., dissenting) ("Pregnancy does not deter, and may even precipitate, physical attacks on women.") (citing brief of the American Psychological Assoc); Hodgson v. Minnesota, 110 S. Ct. 2926, 2938-39, 2939 n.25 (1990). For recent cases in which women charged with fetal neglect appear to have been subject to physical battering by their husbands, see note 334 supra.

445. By this I intend conventional forms of stigma as well as contempt currently directed at "welfare" or "teen" mothers. See Fox Butterfield, Stunning Primary in Massachusetts, N.Y. TIMES, Sept. 20, 1990, at A14 (Massachusetts gubernatorial candidate John Silber explains his opposition to providing welfare for unwed, poor women who "continu[e] having children"). Silber told a radio audience:

When young teenagers walk down the street proud of being pregnant despite the fact that they are not married, you know there has to be some incentive. And it's not merely to be loved by their offspring. It's also because they have the knowledge that they have now Id. married Uncle Sam and Uncle Sam will provide.

446. On pregnancy discrimination in employment before enactment of the Pregnancy Discrimination Act, see Lucinda M. Finley, Transcending Equality Theory: $A$ Way Out of the Maternity and the Workplace Debate, 86 ColuM. L. REv. 1118, 1123-25 (1986). As currently construed, the Act only requires employers to treat a pregnant employee the same as other employees with similar work disabling conditions, and for this and other reasons, pregnancy exclusions continue. See Maureen E. 
involve intellectual and moral judgments, they may brand her, socially or legally, as an irresponsible mother. ${ }^{447}$ Pregnancy, and the period of lactation that follows it, 448 are not merely burdensome, disruptive, or even consuming forms of work. They amplify the gendered judgments and constraints to which women are already subject, exposing them to material and dignitary injuries having nothing to do with the physiology of reproduction, and entangling them in relationships that profoundly define their identity and life prospects.

Finally, notwithstanding changing norms of family life, it remains the case that it is women who perform the vast majority of the labor necessary to make infants into adults. ${ }^{449}$ Mothers are expected to subordinate their personal interests to children in a way that men are not; most women give themselves over to the nurturance of life in a way that men do not-and face

Lally-Green, The Implications of Inadequate Maternity Leave Policies Under Title VII, 16 VT. L. Rev. 223 (1991); California Fed. Sav. \& Loan Ass'n v. Guerra, 479 U.S. 272 (1987) (federal law permits states to require employers to give pregnant employees needing unpaid disability leave up to four months of such leave, to the extent consistent with business necessity); Chambers v. Omaha Girls Club, Inc., 834 F.2d 697 (8th Cir. 1987) (sustaining, under Pregnancy Discrimination Act, dismissal of employee of girls club because she was single and pregnant in violation of club's "role model" rule); Levin v. Delta Air Lines, 730 F.2d 994 (5th Cir. 1984) (allowing airline to ground flight attendants for duration of pregnancy); Alison Leigh Cowan, Trend in Pregnancies Challenges Employers, N.Y. TIMEs, April 17, 1989, at A1 (reporting that 3,600 pregnancy-related complaints have been filed annually with EEOC since 1981); Douglas Martin, About New York: Women Given Cruelest Choice Now Fight Back, N.Y. TIMES, Oct. 21, 1989, at 27 ("'mid-level managers told pregnant correction officers that they must obtain abortions or resign, according to [New York] [C]ity's Department of Investigation"); see also text accompanying notes 302-303 supra (discussing fetalprotective exclusions of women from employment).

447. Public outrage directed at pregnant, drug-dependent women is but one manifestation of this response. Advocates for providing state protection to the fetus in utero believe the pregnant woman has a duty of care to the unborn implicating choices in all aspects of her life, $c f$. note 331 supra, breach of which warrants state intervention, whether in the form of civil liability, criminal prosecution, forcible surgical treatment, "protective" incarceration, or deprivation of child custody. Cf. text accompanying notes $280-285$ supra.

448. The same compound of physiological and social forces that shape the work of gestation governs the work of breast-feeding an infant once it is born. Women are alone physiologically capable of engaging in the work, but the choice to engage in it and the conditions under which it is performed are fundamentally social. Like gestation, breast-feeding an infant is a practice subject to a diverse array of prescriptive norms; women are pressured to perform the work and stigmatized for performing it in highly context-bound ways. Suffice it to observe that a woman nursing a baby will likely meet with approval if she is sitting in her bedroom, and scorn if sitting in a corporate board room.

449. Presently, $45 \%$ of women with pre-school age children withdraw from the labor force to care for them personally, while $55 \%$ continue to engage in some form of paid employment. Felicity Barringer, Census Report Shows a Rise in Child Care and its Costs, N.Y. TIMES, Aug. 16, 1990, at A12; see also RUTH SIDEL, ON HER OWN 204 (1990) (in 1987, 63\% of women with college degrees remained in the work force after bearing a child, as compared with $38 \%$ of high school graduates).

Even when mothers are employed, they continue to perform a larger share of the work of family maintenance than do men. For example, a 1986 study of a Boston-based firm found that employed women work twice as many hours on childcare and homemaking as men, even when the woman's income is greater than the man's, and that married female parents spend a total of 85 hours a week on work, in and out of the home, while married male parents spend 65 hours. Other studies suggest that even where parents share child care, fathers are more likely to 'play' with children, and mothers to carry out most of the caretaking activities. Id. at 202-04; see also ARLIE HochSCHLD, THE SECOND SHIFT: WORKING PARENTS AND THE REVOLUTION AT HOME 271-79 (1989) (research on who does the housework and childcare in two-income households). 
stigmatization, unlike men, if they will not. Consequently, a woman's identity, relations, and prospects are defined by becoming a parent in a way that a man's are not. ${ }^{450}$

While this society celebrates the work of childcare, it continues to view the work of raising children as "women's work." Childcare remains status work, organized and valued in ways that limit the life prospects of those who perform it. Most prominently, childcare is uncompensated labor, traditionally performed under conditions of economic dependency; ${ }^{451}$ consequently, it remains a form of undercompensated labor for those who are paid to assist in the work. ${ }^{452}$ It is not merely the uncompensated character of childcare that betrays its peculiar social valuation. Those who devote their personal energies to raising children are likely to find their freedom to participate in so-called public sphere activities impaired for years on end, for the evident reason that most activities in the realms of education, employment, and politics are defined and structured as incommensurate with that work. ${ }^{453}$ Thus, a woman who becomes a parent will likely find that the energy she invests in childrearing will compromise her already constrained opportunities and impair her already unequal compensation in the work force ${ }^{454}$-all the more so

450. For these reasons, women as a group more frequently compromise employment opportunities to accommodate family needs than do men. Cf. Deborah L. Rhode, Perspectives on Professional Women, 40 STAN. L. REv. 1163, 1183-87 (1988) (examining accommodations of familial and occupational commitments among professionals).

451. On the uncompensated character of the work of family maintenance, see CATHARINE $A$. Mackinnon, Toward a Feminist Theorx of the State 60-80 (1989); The Politics of HOUSEWORK (Ellen Malos ed., 1980); Joan Acker, Class, Gender, and the Relations of Distribution. 13 Signs 473 (1988); Heidi I. Hartmann, The Family as the Locus of Gender, Class, and Political Struggle: The Example of Housework, in FEMINISM AND METHODOLOGY 109 (Sandra Harding ed., 1987).

452. An analysis of the median weekly wages of female private household workers (averaged for 1976-1984) shows African-American women earning \$143, Hispanic women earning \$148, and white women earning \$124. The same statistical source shows median weekly wages for all occupations, with African-American women averaging $\$ 242$, Hispanic women at $\$ 224$, and white women at \$264. See Suzanne Goldberg, In Pursuit of Workplace Rights: Household Workers and a Conflict of Laws, 3 YALE J.L. \& FEMINISM 63, 70 \& n.25 (1990).

On the historical connections between women's domestic work in the family and the organization and compensation of domestic "help," see FAYE E. DUDDEN, SERVING WOMEN: HouseHOLD SERvice In Nineteenth-Century AMERICA (1983). For a discussion of some of the contemporary linkages between the maternal role and the work of day-care providers, see Margaret $\mathrm{K}$. Nelson, Mothering Others' Children: The Experiences of Family Day-Care Providers, 15 Signs 586 (1990).

453. For example, an article in the American Bar Association Joumal offered women entering the practice of law the following tips for success:

Don't "shirk late hours or weekend projects." Don't cook and tell, i.e., avoid going home to cook dinner-or if you do, don't let any one know. Keep your "personal life in the background. ... . Never make excuses based on the needs of a spouse or children. ..." Rhode, supra note 450, at 1186, quoting Nell B. Strachan, $A$ Map for Women on the Road to Success, A.B.A. J., May 1984, at 94, 94-95; see also R. SIDEL, supra note 449, at $200-01$ (in medical profession, it may be acceptable for doctors to take time off for traditionally male responsibilities, but not for traditionally female responsibilities associated with family care). Those women who do attempt to accommodate work and family commitments are often penalized for it. See Leslie Bender, Sex Discrimination or Gender Inequality?, 57 FoRdHAM L. REV. 941,943 n.10 (1989); Claudia Deutsch, Saying No to the 'Mommy Track,'N.Y. TIMES, Jan. 28, 1990, at 29 (describing "Mommy Track" as a "devil's bargain"); Women in the Work Force: The Mommy Track v. the Fast Track, N.Y. TrMES, May 21, 1989, at 2 (positive and negative responses to "Mommy Track").

454. In analyzing the size of a gender-based "wage gap," it is conventional practice to exclude 
if she raises the child alone, whether by choice, divorce, or abandonment. ${ }^{455}$ Considered in cold dollar terms, it is the institution of motherhood that gives a gendered structure to the economics of family life, and a gendered face to poverty in the nation's life. ${ }^{456}$

\section{Abortion restrictions as status-enforcing state action.}

In assessing the social effects of restrictions on abortion, it is important to observe not only that such regulation compels women to perform the work of bearing and rearing children, but that it lacks any provision that would mitigate or offset the social consequences of enforced motherhood for women. No modern legislature interested in adopting restrictions on abortion has, to my knowledge, offered to compensate women for this work; to protect women's employment and education opportunities while they perform the work of motherhood; or to provide women adequate childcare so that they are not pushed into dependency upon men or the state. Nor has a legislature required that men fathering the children women are forced to bear assume primary responsibility for the work of nurturance and maintenance women typically provide. Thus, when the state enacts restrictions on abortion, it coerces women to perform the work of motherhood without altering the conditions that continue to make such work a principal cause of their secondary social status.

For this reason, state action compelling motherhood injures women in predictable ways. Both the work of childbearing and the work of childrearing compromise women's opportunities in education and employment; neither the work of childbearing nor the work of childrearing produces any

variables that may contribute to such a gap but that do not reflect the operations of sex discrimination in employment, at least as conventionally understood. It should be noted that such variablesfor example, whether individuals work full-time or part-time, their general experience in the labor force, and their tenure with their employer-are all crude biographical proxies for time women devote to care of home and children. Cf. Paul Weiler, The Wages of Sex: The Uses and Limits of Comparable Worth, 99 HARV. L. REv. 1728, 1780-84 (1986) (noting the role of these factors in wage disparities); see also id. at 1786 (citing econometric study suggesting that the "addition of each child enhances the man's earnings by another three percent while depressing that of the woman's by fully ten percent").

455. The National Commission on Children, appointed by the President and Congress in 1989, found that more than half the children in households headed by women are impoverished. T. Berry Brazelton, Why Is America Failing Its Children, N.Y. TIMEs, Sept. 9, 1990, (Magazine), at 40, 42; see also note 456 infra.

456. Almost all single-parent households are headed by women, and these households are disproportionately represented amongst the ranks of the nation's poor. In 1988, nearly a quarter of the nation's children were living in single-parent households; $21.4 \%$ living with their mother only, and $2.9 \%$ with their father only. U.S. BUREaU of the CENSUS, CURRENT POPUlation Reports: Special Studies, Series P-23, No. 162, Studies IN MARRIAGe aNd the Family, at 18. In 1989, more than half of the children who lived in households headed by women lived in poverty, while only 20.3\% of children who lived in single-parent households headed by their father lived below the poverty level. U.S. Bureau of the Census, Current Population Reports, Series P-20, No. 445, MARITAL STATUS AND LIVING ARRANGEMENTS: MARCH 1989, at 37, tbl. 6. Of all poor black families, $73.4 \%$ were maintained by women with no husband present; for white families the comparable figure was $42.1 \%$, and for Hispanic-origin families, $46.8 \%$. U.S. BUREAU OF THE CENSUS, CurRent Population Reports, Series P-60, No. 168, MONey INCOME and Poverty in the UNITED STATES: 1989 , at 10. 
material compensation for women; most often the work of childbearing and the work of childrearing entangle women in relations of emotional and economic dependency-to men, extended family, or the state. None of these consequences is inherent in the physiology of reproduction; all are socially produced, reflecting communal designation of the work of mothering as "women's work." There is no other form of socially essential labor in this society similarly organized or valued: The more effort a woman personally invests in it, the more time she devotes to it, the more inexorably economically dependent she becomes. From this perspective, it is apparent that compelled pregnancy will injure women in context-dependent ways. It may be endured by women who have ordered their lives in conformity with traditional norms of motherhood, but it will profoundly threaten the material and psychic welfare of any woman whose life deviates from this traditional norm, whether by choice or socio-economic circumstance. 457 When the state deprives women of choice in matters of motherhood, it deprives women of the ability to lead their lives with some rudimentary control over the sex-role constraints this society imposes on those who bear and rear children. It makes the social reality of women's lives more nearly conform with social stereotypes of women's lives. Considered from this perspective, choice in matters of motherhood implicates constitutional values of equality and liberty both. ${ }^{458}$

Women are centuries-versed in negotiating the conditions of motherhood, and deriving meaning, value, pleasure, and purpose from work that this society all too frequently disparages. Under such conditions, mothering is work that for a woman, and amongst women, variously promises joy, rage, identity, and entrapment. 459 But the fact that most women will give them-

457. A 1987 survey of abortion patients found that

unmarried cohabiting women are nine times as likely as married women living with their husbands to have an abortion, and separated women are also at high risk. Other characteristics associated with an above-average likelihood of abortion are current school enrollment, current employment, low income, Medicaid coverage, intention to have no more children, and residence in a metropolitan county.

Stanley K. Henshaw \& Jane Silverman, The Characteristics and Prior Contraceptive Use of U.S. Abortion Patients, 20 FAM. PlaN. Persp. 158, 158 (1988); see also id. at 159 (57\% of patients never had abortion before and 27\% had one prior abortion); cf. Skelton, supra note 269, at 1 (Women who admitted to poll takers that they had had an abortion "tended to be better educated, working full time, earning good salaries and generally representative of every racial and ethnic group. They also tended to be either childless or the parent of just one child, single, a baby boomer and living in metropolitan areas.").

In 1987, when a group of abortion patients was asked about their reasons for seeking an abortion, three-quarters said that having a baby would interfere with work, school, or other responsibilities, two-thirds said they could not afford to have a child, and half said that they did not want to be a single parent or had relationship problems. Aida Torres \& Jacqueline Darroch Forrest, Why Do Women Have Abortions?, 20 Fam. Plan. Persp. 169, 169 (1988).

458. See Kenneth L. Karst, The Freedom of Intimate Association, 89 YALE L.J. 624, 659 (1980) ("The freedom to choose one's place in society, rather than accept an inferior status as Nature's legacy, is both a symbol of equality and an effective instrument for attaining it. There is nothing incongruous about protecting the freedom of intimate association through application of the equal protection clause."); see also note 367 supra (privacy and Thirteenth Amendment analyses of abortion-restrictive regulation that emphasize its caste- or status-enforcing aspects).

459. See, e.g., ADRIENNE RICH, OF WOMAN BORN: MOTHERHOOD AS EXPERIENCE AND IN- 
selves to children in ways that belie what is taken from them, does not alter the fact that coercing motherhood is an act of violence against women, ${ }^{460}$ one that devalues what women give, and give up, in parenting and who they might be apart from that work.

Restrictions on abortion thus offend constitutional guarantees of equal protection, not simply because of the status-based injuries they inflict on women, but also because of the status-based attitudes about women they reflect. For centuries, this society has defined women as mothers and defined the work of motherhood as women's work. These are the assumptions which make it "reasonable" to force women to become mothers. Absent these deep-rooted assumptions about women, it is impossible to explain why this society insists that restrictions on abortion are intended to protect the unborn, and yet has never even considered taking action that would alleviate the burdens forced motherhood imposes on women.

Restrictions on abortion refiect the kind of bias that is at the root of the most invidious forms of stereotyping: a failure to consider, in a society always at risk of forgetting, that women are persons, too. It is a bias that manifests itself in this society's unreflective expectation that women should assume the burdens of bearing and rearing future generations, its tendency to denigrate the work of motherhood, and its readiness to castigate women who seek to avoid maternity as lacking in humanity, proof of which consists in a woman's failure perfectly to subordinate her energies, resources, and prospects to the task of making life-to a degree that men, employers, and the community as a whole most often will not.

This society has "unclean hands" in matters respecting motherhood. While it may possess the power, it sorely lacks the moral grounds to "balance" the rights of women and the unborn as if it were a disinterested bystander to a conflict thrust upon women by nature. We may stand a century away from the attitudes expressed in the nineteenth century campaign, but we are still generations away from any prospect of transcending their ideological or institutional legacy. In a society that viewed women as full and equal citizens-as something more than particularly valuable means to an important social end-the test for determining the constitutionality of abortion-restrictive regulation might be: Has the state asserted its interest in promoting the welfare of the unborn in a fashion consistent with promoting the welfare of women?

StTtuTton (1986); Alice WALKer, In SEARCh OF OUR Mothers' Gardens (1983); Regina Austin, Sapphire Bound!, 1989 WIS. L. REV. 539, 558-74; Eileen Boris, Looking at Women's Historians Looking At "Difference," 3 WIS. WoMEN's L.J. 213, 218-22 (1987); Robin West, Jurisprudence and Gender, 55 U. CHI. L. REV. 1, 28-36 (1988).

460. Cf. West, supra note 459 , at 28-36 (considering wanted, and especially, unwanted, pregnancy and motherhood as invasive experiences for women, which can constitute an assault upon body and identity in a fashion analogous to intercourse or rape); $i d$ at 29 ("[i]nvasion and intrusion, rather than intimacy, nurturance and care, is the 'unofficial' story of women's subjective experience of connection" to others); Ellen Willis, Abortion: Is a Woman a Person?, in Powers OF DESIRE: The Polrtics of Sexuality 471, 473 (Ann Snitow, Christine Stansell \& Sharon Thompson eds., 1983) ("However gratifying pregnancy may be to a woman who desires it, for the unwilling it is literally an invasion-the closest analogy is the difference between lovemaking and rape."). 
In an inchoate fashion, Roe embodied this understanding. The Court understood that regulation of women's conduct premised on a theory of fetal personhood would deeply conflict with public recognition of women's personhood. Roe's trimester framework accommodated this conflict practically, but gave only a partial account of its sense. By allowing states to prohibit abortions at the point of fetal viability, the Court hoped to craft a constitutional compromise. But Roe's viability rule can function as a legitimate constitutional compromise only if it provides women reasonable access to abortion in the early months of pregnancy, the period they normally seek abortions; and if it is understood, not simply as an ambiguous recognition of fetal personhood, but as an explicit constitutional affirmation of women's personhood. The Constitution requires government to respect women's freedom to refuse motherhood because decisions about abortion are both deeply personal and profoundly social: When a pregnant woman decides whether to become a mother, she faces dilemmas in which the community itself is inextricably complicit.

State action on behalf of the fetus in utero must find its constitutional bearings, and constraints, in the community's relation to the citizen in whom unborn life resides. In this sense, the common law criterion of quickening gave surer moral guidance to the regulation of abortion than the "scientific" concept of viability with which Roe replaced it. At least the common law criterion of quickening located the unborn internal to a born, sentient being, rather than presenting the unborn as an autonomous life form-an illusion sustained for more than a century now by medical rhetoric. If Roe survives in some form, it will be because those charged with expounding federal and state constitutions do not, in their hearts, credit this dehumanizing myth of human genesis. It will be because they recognize that women's lives are required to make potential life recognizable as a person, and recognize that because women are equal citizens too, their labor in bearing life is a gift with which they can endow the community, not a resource the community can expropriate to its use.

\section{ConClusion}

For too long this nation has regulated women's status through the institution of motherhood. Its judgments about the ways in which it is reasonable to impose on women as mothers are deeply distorted by a long history of denigrating, controlling, and using women as mothers. For this reason, the physiological paradigms that currently dominate review of reproductive regulation are deeply pernicious. They invite public actors to use state power against women without the minimal forms of self-scrutiny that requirements of equal protection normally impose. They invite abusive exercise of public power against women because they suspend rudimentary safeguards on the exercise of such power in precisely those circumstances where safeguards are most needed. Before this society rushes to judge women's conduct toward the unborn, it ought to reflect upon its own con- 
duct toward women. Instead of devising new ways to control women as mothers, it needs to promote the welfare of future generations by means that respect and support women in their work as mothers. Only then will the story of the nineteenth century criminal abortion campaign be a closed chapter in American history-and not a continuing part of American life. 
Heinonline -- 44 Stan. L. Rev. 382 1991-1992 